\title{
CALCAREOUS MARINE ALGAE FROM THE CARBONIFEROUS (MOSCOVIAN-GZHELIAN) OF THE CANTABRIAN ZONE (NW SPAIN)
}

\author{
Bernard MAMET ${ }^{1}$ and Elisa VILLA ${ }^{2}$ \\ ${ }^{1}$ Département des Sciences de la Terre et de l'Environnement, Faculté des \\ Sciences, Université Libre de Bruxelles, av. F. D. Roosevelt 50, B-1050 Bru- \\ xelles, Belgique. \\ 2 Departamento de Geología, Universidad de Oviedo, c/ Jesús Arias de Velasco \\ s/n, 33005 Oviedo, Spain. evilla@geol.uniovi.es
}

Mamet, B. and Villa, E. 2004. Calcareous marine algae from the Carboniferous (Moscovian-Gzhelian) of the Cantabrian Zone (NW Spain). [Algas calcáreas marinas del Carbonífero (Moscoviense-Gzheliense) de la Zona Cantábrica (NO de España).] Revista Española de Paleontología, 19 (2), 151-190. ISSN 0213-6937.

\begin{abstract}
A taxonomic revision of shallow-water Carboniferous (Pennsylvanian) red and green algae observed in Ponga, Picos de Europa and Pisuerga-Carrión Units in NW Spain is presented. Some microproblematics are included. Thirty-two genera are described; three genera and four species are new: Anatolipora cantabriensis n. sp., Pelayella multiporosa n. gen., n. sp., Kasimophyllum demuesensis n. gen., n. sp. and Penella pongaensis n. gen., n. sp. The microflora is typically Western Paleotethyan and remarkably similar to that observed in the Carnic Alps and Central Urals.
\end{abstract}

Keywords: Carboniferous microflora, taxonomy, green algae, red algae.

\section{RESUMEN}

Se realiza una revisión de las algas verdes y rojas de ambientes someros registrados en los depósitos del Carbonífero superior de las unidades del Ponga, Picos de Europa y Pisuerga-Carrión en el NO de España, incluyendo algunos grupos problemáticos. Se describen formas pertenecientes a treinta y dos géneros, entre las que se encuentran tres nuevos géneros y cuatro nuevas especies: Anatolipora cantabriensis n. sp., Pelayella multiporosa n. gen., n. sp., Kasimophyllum demuesensis n. gen., n. sp. and Penella pongaensis n. gen., n. sp. La microflora estudiada es típica del Paleotethys occidental, presentando grandes semejanzas con la que se ha descrito en los Alpes Cárnicos y en los Urales Centrales.

Palabras clave: Microflora carbonífera, taxonomía, algas verdes, algas rojas.

\section{INTRODUCTION}

The abundance of algae in the Carboniferous of northern Spain is well documented since the pioneering work of Rácz (1966 a, b) who reported their morphology with great taxonomic accuracy. These two papers by Rácz, as well as other studies on algae (or containing information related to algae) developed subsequently in the Cantabrian Zone (Riding, 1979; Bowman, 1979; Eichmüller and Seibert, 1984; Eichmüller, 1985; Rácz, 1984; Dingle et al., 1993; Hensen et al., 1995; Barba Regidor, 1998; Samankassou, 2001; Della Porta et al., 2002; Della Porta, 2003), dealt mostly with Bashkirian and (especially) Moscovian materials. Algae from the final part of the Carboniferous succession, e. g., that embracing from the uppermost Moscovian to the lower Gzhelian, have remained rather unknown until recently as a result of the fact that the stratigraphy of this final part of the Carboniferous succession has not been so deeply investigated in the Cantabrian Zone until much later than the older Carboniferous. Among the few papers containing information on latest Carboniferous algae, we can mention studies on Kasimovian algae by Rodríguez and Moreno-Eiris (1986) and Minwegen (2001), the latter also studying numerous Moscovian localities. 
During the late 1980's and 1990's, the SCCS program for establishing levels of correlation in the upper part of the Carboniferous system has led to an intensive biostratigraphic study of successions of this age through the Cantabrian Zone and, particularly, of those outcropping in the Picos de Europa structural unit (Figs. 1-2). In parallel with these studies, several investigations on the regional geology of the eastern part of the Cantabrian Zone, the area where younger Carboniferous successions of this zone exist, were carried out, leading to a a better knowledge of its stratigraphy (Villa and Martínez García, 1989; Martínez García and Villa, 1998, 1999; Venturini et al., 1998; Sánchez de Posada et al., 1999). Especially significant is the study on the stratigraphy and sedimentology of the latest Carboniferous successions of the norhern part of the Picos de Europa massifs carried out by MerinoTomé et al. (2001).

\section{UPPERMOST CARBONIFEROUS FROM THE EASTERN CANTABRIAN ZONE}

The Cantabrian Zone (Lotze, 1945), situated in the northwestern part of the Iberian Peninsula, constitutes a foreland basin, deformed by thin-skinned tectonics into an arcuate fold belt. Stratigraphic and structural characters have been used by Julivert (1971) and Pérez Estaún et al . (1988) to distinguish within the Cantabrian Zone several major geological provinces (or structural units; Fig. 1).

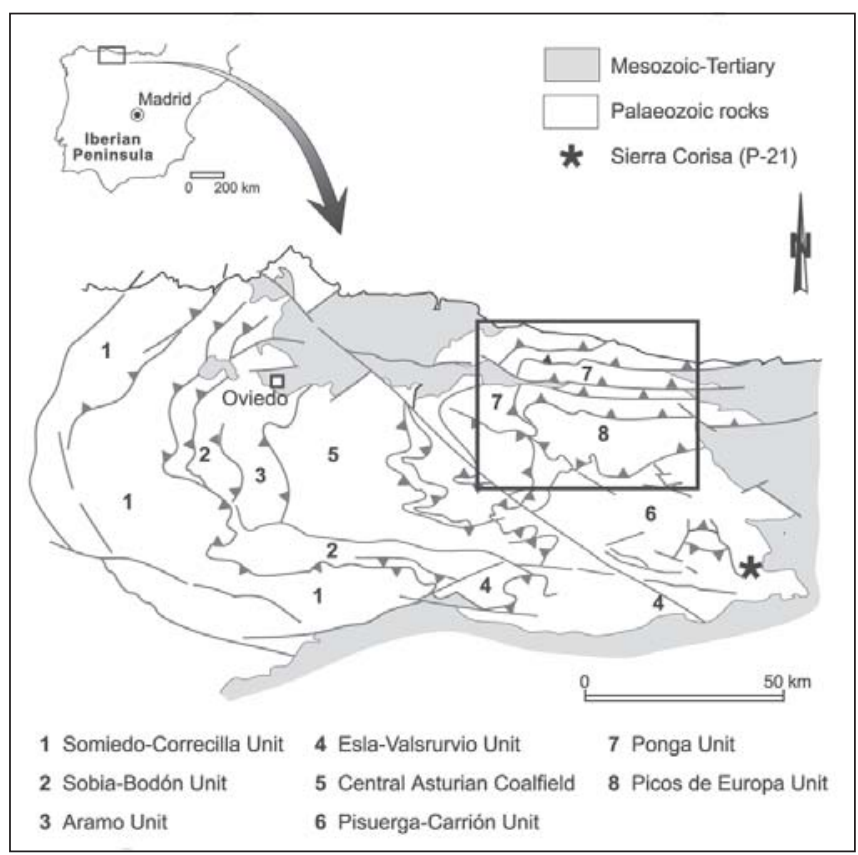

Figure 1. Sketch showing the main structural units of the Cantabrian Zone. Box shows the area enlarged in figure 2 .
These units spread along the provinces of Asturias, Cantabria, León and Palencia, in northern Spain.

The most complete Carboniferous successions of the Cantabrian Zone are present in the eastern units (Central Asturian Coalfield, Ponga Unit, Picos de Europa Unit, and Pisuerga-Carrión Unit). A remarkable feature in these successions is that, during late Carboniferous, the sedimentation was strongly influenced by tectonics, resulting in synorogenic deposits with important facies and thickness variations. As a result of the west-eastern progression of deformation, the top of the Carboniferous succession becomes younger in an eastern direction. The Picos de Europa Unit is the only region where sedimentation in a shallow carbonate platform lasted until Gzhelian.

Materials analyzed in this work come from sections and localities situated in the Ponga Unit (Pen section), Picos de Europa Unit (Las Llacerias, Demués, Berodia-I, Berodia-II sections, and Inguanzo locality), and PisuergaCarrión Unit (Sierra Corisa locality). The location of sections is shown in figures 1-2, the correlation in figure 3, and the stratigraphic position of samples studied in tables $1-2$. The list of species, as well as their range in the sections and localities studied in this paper are given in table 3 .

\section{Pen section}

This section (Figs. 2-3, Table 2) exposes an unconformable marine succession consisting of a thin calcareous band at the base, which is overlain by siliciclastics. The calcareous band yields fusulinaceans belonging to the Protriticites Zone and algae at closely situated various levels (samples BM-78, BM-79, BM-85). Further stratigraphic information on these deposits is given in Martínez García et al. (1985) and Villa (1995).

\section{Las Llacerias section}

This section outcrops in the vicinity of Covadonga, Asturias (Figs. 2-3, Table 1). The upper part of this section (the one studied in this paper) is the most extensively studied succession of the Cantabrian Zone embracing the Moscovian/Kasimovian transition. This part corresponds to the Picos de Europa (part) and Las Llacerias formations (Fig. 3). Diverse fossil groups (brachiopods, corals, conodonts, fusulinaceans, spores and algae) have been collected from these strata (Marquínez et al., 1982; Villa et al., 1993, 1997; Coquel and Rodríguez, 1994; Méndez, 2002). Their age has been mainly established on the base of the fusulinoidean faunas and it ranges from upper Krevyakinian to upper Khamovnikian (van Ginkel and Villa, 1999; Villa and van Ginkel, 2000). The upper part of the Picos de Europa Formation represents sedimentation in a platform-lagoonal environment which evolved towards more open marine conditions. Towards the top of the formation organic build-ups are found. According to Bahamonde et al. (2000), the uppermost part of the Picos 


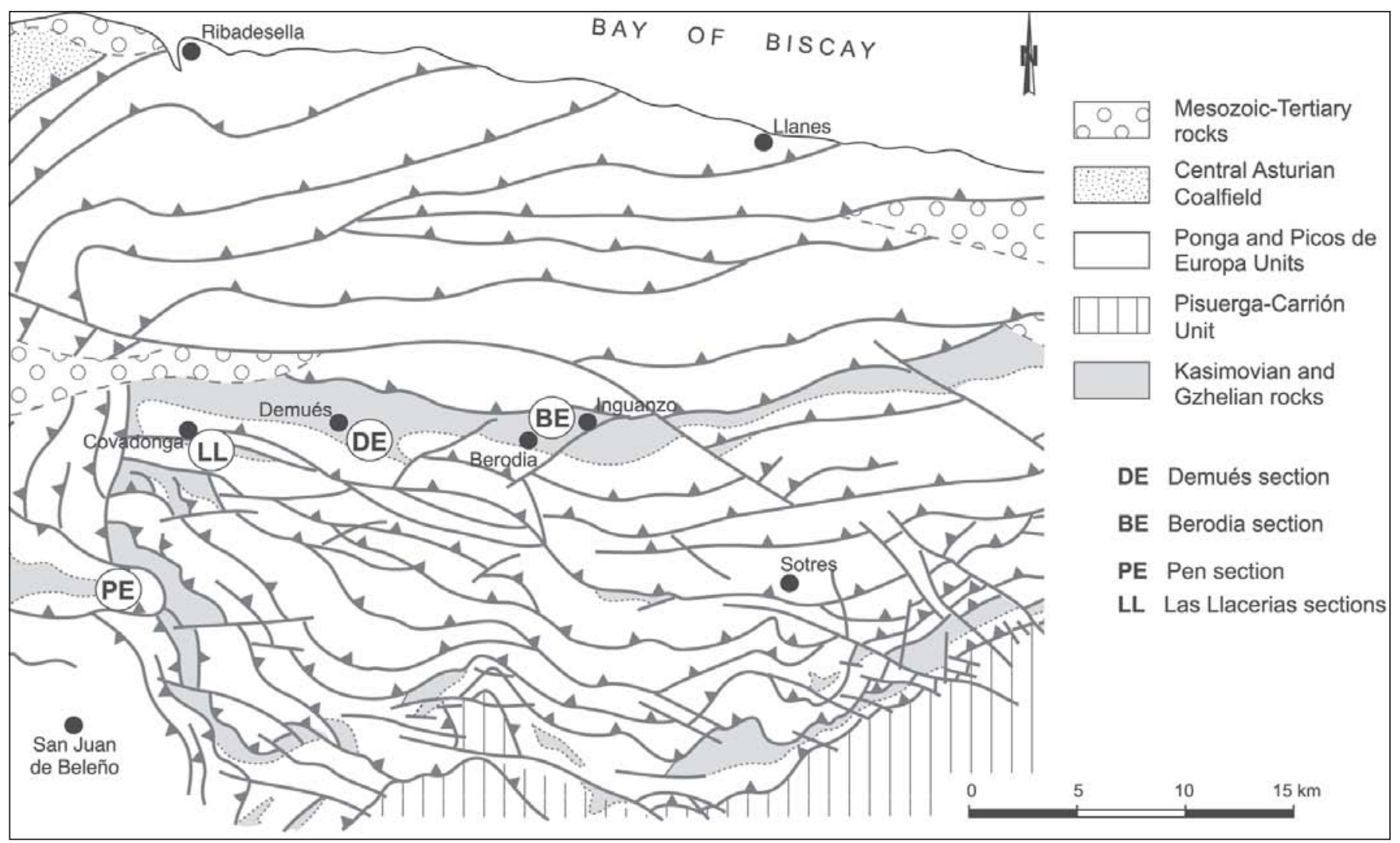

Figure 2. Geological sketch of the area around the sections studied in the Ponga and Picos de Europa structural units.

de Europa Formation represents the evolution from a shallow to a drowned platform, which was finally replaced by a mixed ramp represented by Las Llacerias strata. The latter consists of packstones and wackestones alternating with grainstones and marls. Its upper part corresponds to a megasequence of tempestites made up of grainstone to mudstone. On the whole, the materials of the Las Llacerias Formation are deposits that accumulated on a storm-dominated monoclinal platform-slope (ramp), under conditions of high sedimentation rate (Leyva in Villa et al., 1993).

\section{Demués section}

This section (Figs. 2-3, Table 2) exposes strata belonging to the Demués Formation along the trail leading from the village of Demués to the pastures in the northern slope of the Picos de Europa mountains. Different studies on the stratigraphical, sedimentological and paleontological characteristics of this section have been carried out by Bruner et al. (1998), Martínez García and Villa (1998), and Sánchez de Posada et al. (1999, 2002). The Demués Formation is composed of an alternation of limestones, marls, shales, carbonaceous shales, sandstones and calcareous conglomerates, and a thin coal-seam. Marine beds yield fossils belonging to many benthic groups (especially brachiopods, porifera, molluscs, foraminifers, ostracods, and algae), all of them reflecting shallow-marine environments. Spores have been recovered from beds at differ- ent levels throughout the entire succession. Fusulinaceans and spores allowed dating these rocks in terms of both the West-European and the Russian stratigraphical scales. The succession at Demués section ranges in age from uppermost Moscovian or basal Kasimovian to the middle part of the Kasimovian (upper Khamovnikian) in the Russian stratigraphic scale, and probably from Cantabrian (lower?) to a level near the Barruelian/Stephanian B boundary in the West European stratigraphic scale (Sánchez de Posada et al. 1999, 2002).

\section{Berodia sections}

The name Berodia-I and Berodia-II refer to Puentellés Formation outcrops located along the road leading from the Casaño River valley to the small village of Berodia (Figs. 2-3, Table 2). The Puentellés Formation outcrops in this area splitted in two structural units, which are separated by a thrust fault (Martínez García and Villa, 1998). Berodia-I is the section located closest to the village of Berodia.

The Puentellés Formation is a thick calcareous succession ranging from upper Kasimovian to lower Gzhelian within which two different members can be recognized: a lower member consisting of reworked and resedimented carbonates, and an upper member, made up of authocthonous limestones (Merino-Tomé et al., 2001). Lower member strata are bedded alternations of calcareous breccias 


\begin{tabular}{|c|c|c|c|}
\hline Sample & $\begin{array}{c}\text { Stratigraphic position with respect to } \\
\text { samples in Villa et al, 1997, and Villa \& } \\
\text { van Ginkel, } 2000\end{array}$ & Age & Fusulinid zone \\
\hline $\mathrm{BM}-11$ & $\begin{array}{l}\text { Picos de Europa Fm. (upper part of the } \\
\text { upper member), } 4 \mathrm{~m} \text { below LL-9001 }\end{array}$ & $\begin{array}{l}\text { Late Moscovian } \\
\text { (Myachkovian) }\end{array}$ & $\begin{array}{l}\text { Fusulinella Zone (upper } \\
\text { part) }\end{array}$ \\
\hline BM-12 & idem & idem & idem \\
\hline $\mathrm{BM}-13$ & idem, $0.5 \mathrm{~m}$ above LL-9001 & idem & idem \\
\hline BM-14 & idem, $4 \mathrm{~m}$ above LL-9001 & idem & idem \\
\hline $\mathrm{BM}-16$ & idem, $0.5 \mathrm{~m}$ below LL-9003 & idem & idem \\
\hline $\mathrm{BM}-17$ & idem, equivalent to LL-9003 & late Myachkovian & idem \\
\hline $\mathrm{BM}-18$ & idem, $0.4 \mathrm{~m}$ below LL-9004 & idem & idem \\
\hline BM-19 & idem, equivalent to LL-9005 & idem & idem \\
\hline BM-25 & idem, $0.8 \mathrm{~m}$ above LL-9008 & idem & idem \\
\hline BM-28 & idem, equivalent to LL-9009 & idem & idem \\
\hline BM-31 & idem, $4.8 \mathrm{~m}$ above LL-9009 & idem & idem \\
\hline BM-38 & idem, equivalent to LL-9011 & $\begin{array}{l}\text { Moscovian/Kasimovian } \\
\text { transition interval }\end{array}$ & Protriticites Zone \\
\hline BM-39 & idem, 2 m above LL-9011 & idem & idem \\
\hline BM-40 & idem, $4 \mathrm{~m}$ above LL-9011 & idem & idem \\
\hline BM-46 & idem, $4 \mathrm{~m}$ below LL-9014 & $\begin{array}{c}\text { earliest Kasimovian (early } \\
\text { Kreviakinian) }\end{array}$ & idem \\
\hline BM-47 & idem, equivalent to LL-9014 & idem & idem \\
\hline BM-52 & idem, equivalent to LL-9016 & $\begin{array}{l}\text { early Kasimovian } \\
\text { (Kreviakinian) }\end{array}$ & idem \\
\hline BM-63 & idem, equivalent to LL-9024 & idem & idem \\
\hline BM-69 & Las Llacerias Fm., equivalent to LL-9031 & idem & idem \\
\hline BM-70 & idem, equivalent to S-236 & idem & idem \\
\hline BM-72 & idem, equivalent to LL-9034 & idem & idem \\
\hline BM-74 & idem, equivalent to LL-9037 & $\begin{array}{l}\text { Kasimovian (early } \\
\text { Khamovnikian) }\end{array}$ & Montiparus Zone \\
\hline $\mathrm{BM}-74 \mathrm{~B}$ & idem, equivalent to LL-9038 & idem & idem \\
\hline BM-76 & idem, equivalent to LL-9044 & late Khamovnikian & idem \\
\hline $\mathrm{BM}-76 \mathrm{~B}$ & idem, slightly above LL-9044 & idem & idem \\
\hline BM-77B & idem, equivalent to LL-9047 & idem & idem \\
\hline
\end{tabular}

Table 1. Stratigraphic position and age of samples from Las Llacerias section mentioned in this paper.

and conglomerates, pebbly sandstones, graded and laminated silty and sandy limestones, skeletal grainstones and bioturbated marly limestones and marls. Accumulations of the fusulinoidean Ferganites occur in this member at several levels (Villa and Bahamonde, 2001). The upper member consists of dark pseudo-nodular mudstones and skeletal wackestones with intercalations of thick bedded algal bafflestones and isolated mud mounds. In contrast to the lower member, the upper one yielded more varied fusulinacean assemblages, including Rauserites, Jigulites, Quasifusulina and Ferganites, which allowed accurate dating (Villa and van Ginkel, 1999; Villa and Ueno, 2002; Villa et al., 2003). Further data on the sedimentological characteristics of this formation are in Merino-Tomé et al. (2001), Villa and Bahamonde (2001), and Villa et al. (2003). With the exception of one taxon, all algal samples from the Puentellés Formation studied in this paper have been collected from the upper member. 


\begin{tabular}{|c|c|c|c|c|}
\hline Loc./Sect. & Sample & Stratigraphic position & Age & Fusulinid zone \\
\hline \multirow{2}{*}{$\begin{array}{l}\text { Sierra } \\
\text { Corisa }\end{array}$} & P21-39 & Corisa Formation & $\begin{array}{l}\text { late Moscovian } \\
\text { (Myachkovian) }\end{array}$ & $\begin{array}{c}\text { Fusulinella Zone } \\
\text { (upper part) }\end{array}$ \\
\hline & P21 & idem & idem & idem \\
\hline \multirow{3}{*}{ Pen } & BM-78 & Pen Limestone & $\begin{array}{l}\text { early Kasimovian (late } \\
\text { Krevyakinian) }\end{array}$ & Protriticites Zone \\
\hline & BM-79 & idem & idem & idem \\
\hline & BM-85 & idem & idem & idem \\
\hline \multirow{3}{*}{ Demués } & BM-276 & $\begin{array}{l}\text { Demués Formation, top of phylloid } \\
\text { mound, } 130 \mathrm{~m} \text { above base of the } \\
\text { section }\end{array}$ & Kasimovian & $\begin{array}{l}\text { Protriticites } \\
\text { Zone(?) }\end{array}$ \\
\hline & BM-277 & $\begin{array}{l}\text { Demués Formation, upper part, } 191 \\
\text { me above base of the section }\end{array}$ & $\begin{array}{l}\text { Kasimovian (probably } \\
\text { Khamovnikian) }\end{array}$ & Montiparus Zone(?) \\
\hline & BM-281 & Demués Formation, top of the section & $\begin{array}{l}\text { Kasimovian } \\
\text { (Khamovnikian) }\end{array}$ & Montiparus Zone \\
\hline \multirow{4}{*}{ Berodia-I } & BM-98 & $\begin{array}{l}\text { Puentellés Fm, } 20 \text { below top of the } \\
\text { lower member }\end{array}$ & $\begin{array}{l}\text { late Kasimovian } \\
\text { (Dorogomilovian) }\end{array}$ & Rauserites Zone \\
\hline & BM-101 & $\begin{array}{c}\text { Puentellés Fm., flanks of phylloid } \\
\text { mound, } 10 \mathrm{~m} \text { above base of the upper } \\
\text { member }\end{array}$ & probably early Gzhelian & Rauserites Zone \\
\hline & BM-103 & idem, but $2 \mathrm{~m}$ higher than $\mathrm{BM}-101$ & idem & idem \\
\hline & BM-105 & idem, but $5 \mathrm{~m}$ higher than BM-101 & idem & idem \\
\hline \multirow{3}{*}{ Berodia-II } & $\mathrm{BM}-122$ & $\begin{array}{l}\text { Puentellés Fm. (base of the upper } \\
\text { member) }\end{array}$ & probably early Gzhelian & Rauserites Zone \\
\hline & $\mathrm{BM}-123$ & $\begin{array}{l}\text { idem, } 7 \mathrm{~m} \text { above base of the upper } \\
\text { member, flank of phylloid mound }\end{array}$ & idem & idem \\
\hline & BM-128 & $\begin{array}{c}\text { Puentellés Fm., upper part of the } \\
\text { upper member }\end{array}$ & early Gzhelian & idem \\
\hline \multirow{2}{*}{ Inguanzo } & BM-251 & Puentellés Fm. & $\begin{array}{c}\text { either late Kasimovian or } \\
\text { early Gzhelian }\end{array}$ & Rauserites Zone \\
\hline & BM-257 & idem & idem & idem \\
\hline
\end{tabular}

Table 2. Stratigraphic position and age of other samples, apart from those of the Las Llacerias section, mentioned in this paper.

\section{Inguanzo locality}

The two samples labeled "Inguanzo" have been collected from strata of the upper member of the Puentellés Formation exposed at the cut road leading to the Casaño River valley to the village of Inguanzo (Fig. 2, Table 2), situated $1 \mathrm{~km}$ east of Berodia. This outcrop constitutes the eastern extension of the unit exposed at the Berodia-II section.

\section{Sierra Corisa locality}

The Sierra Corisa locality belongs to the Pisuerga Carrión Unit (Fig. 1, Table 2) of the Cantabrian Zone. It is situated in the Castillería Syncline, in the northern part of the Palencia province. Samples for the present study were collected from the Corisa Formation, a thick calcareous succession of late Myachkovian age (van Ginkel, 1965; van Ginkel and Villa, 1991).

\section{GENERALITIES ON CALCAREOUS ALGAE}

Algae are important contributors to the formation of modern bioconstructions ("reefs") and carbonate platforms and it can be inferred that they have played the same role since the Paleozoic (Wray, 1977). Taxonomic problems are present, but classification difficulties should not blur the geological importance of the microflora. 


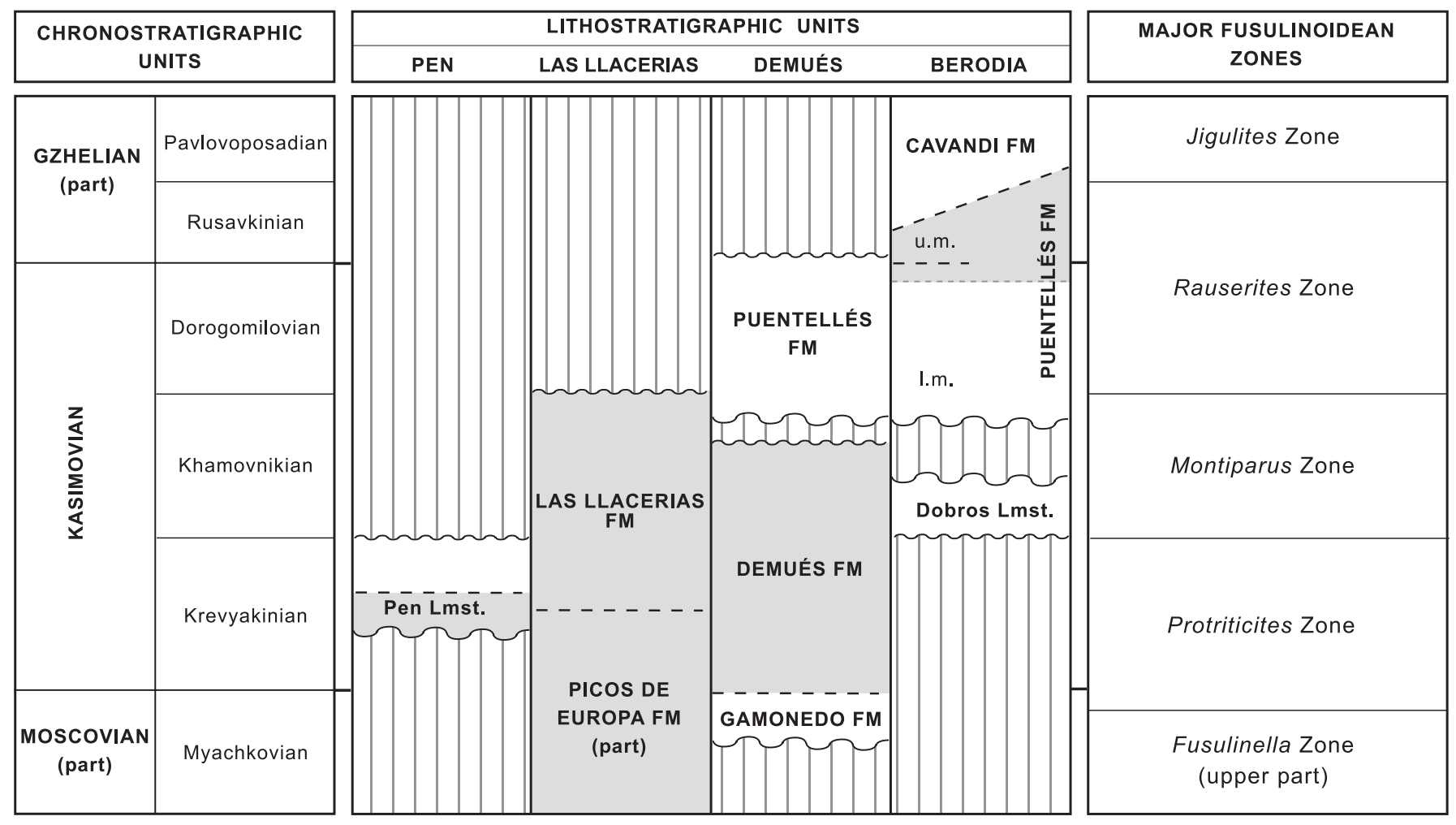

Figure 3. Correlation of chronostratigraphic units, lithostratigraphic units, and fusulinoidean zones. Shaded intervals correspond to strata sampled in this study (1. m. and u. m. = lower and upper member of the Puentellés Formation).

We have also included, in this article, a number of microproblematics that play a crucial role in carbonate accumulations. We are conscious that their taxonomic position is open to question but, associated with the microflora, they equally contribute to the microfacies.

Algal proliferation is linked to various factors such as biotic turnover, nutrients, paleolatitude, turbidity, upwelling, temperature (Kroeger et al., 2003). Thus, a warm low latitude photozoan association and its opposite, a cold high latitude heterozoan association, can occur in Late Paleozoic sequences (e. g., in the Carnic Alps; Samankassou, 2002).

The presently described algae are basically light dependent. The upper part of the photic zone is favorable to all categories (cyanophytes, chlorophytes, phaeophytes, rhodophytes). The euphotic/dysphotic zone sees the progressive elimination of the first two categories. The dysphotic zone is characterized by the latter two categories that peter out in the aphotic zone (Madi et al., 1996).

As the Carboniferous succession of the Cantabrian Zone is cyclic, with concommitant variations in bathymetry/luminosity, the nearly complete gamut of algae is observed. This abundance and diversity indicate overall warm water temperature and not necessarily mixing of cold versus warm waters as suggested by Samankassou (2002) for the Auernig Group in the Carnic Alps.
The most important algal flora that contribute to Carboniferous Paleotethyan carbonates are (Mamet et al, 1987; Mamet, 1992):

1. Archaeolithophyllum, Kasimophyllum and Archaeolithoporella (encrusting red algae) (Wahlman, 1988; Razgallah and Vachard, 1991; this paper).

2. Beresellids (Beresella, Dvinella) (green algae) (Mamet and Stemmerik, 2000).

3. Donezella (discussion in Della Porta et al., 2002).

4. Komia-Ungdarella (red algae) (Mamet, 1991).

5. Petschoria (red alga) (Mamet et al., 1987).

6. Phylloid algae (Eugonophyllum, Ivanovia, Neoanchicodium) (discussion in Torres, 1997, fide Wahlman, 2002).

7. Tubiphytes (for references and discussion, see Senowbari-Daryan and Flügel, 1993).

8. Uraloporella (green alga) (Mamet and Villa, 1995).

\section{PREVIOUS STUDIES ON CALCAREOUS ALGAE FROM THE CANTABRIAN ZONE}

As mentioned above, pioneering works on algae from the Cantabrian Zone have been those by Rácz (1966a, 1966b). In these papers, Rácz proposed that Donezella and 


\begin{tabular}{|c|c|c|c|c|c|c|c|c|c|}
\hline & \multirow{2}{*}{\multicolumn{2}{|c|}{$\begin{array}{c}\text { MOSCOV. (part) } \\
\text { Myachkovian }\end{array}$}} & \multicolumn{5}{|c|}{ KASIMOVIAN } & \multirow{2}{*}{\multicolumn{2}{|c|}{$\begin{array}{c}\text { GZHEL. (part) } \\
\text { Rusavkinian }\end{array}$}} \\
\hline & & & \multicolumn{2}{|c|}{ Kreviakinian } & \multicolumn{2}{|c|}{ Khamovnikian } & \multirow[t]{2}{*}{ Dorogom. } & & \\
\hline Anatolipora cantabriensis $\mathrm{n} . \mathrm{sp}$. & : & & & & & & & & $\vdots$ \\
\hline Anchicodium funile Johnson 1948 sensu Torres \& Baars 1992 & - & & & & & & & & $\vdots$ \\
\hline Anthracoporella spectabilis Pia 1920 & 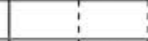 & - & 回 & - & 圆 & & & & \\
\hline Anthracoporella vicina Kochansky and Herak 1960 & - & & $\mathbf{E}$ & - & & & & & \\
\hline Anthracoporellopsis machaevii Maslov 1956 & - & - & & & & & & & \\
\hline Archaeolithophyllum johnsoni Rácz 1966 & - & & & - & & & & a? & $\vdots$ \\
\hline Archaeolithophyllum delicatum Johnson 1956 & $\vdots$ & & & & 田 & & & 口? & $\vdots$ \\
\hline Beresella herminae Rácz 1966 & : & - & & & & & & & $\vdots$ \\
\hline Berestovia filaris (Berchenko 1982) & $\vdots$ & & 㽣 & & & & & $\mathbf{\square}$ & 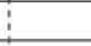 \\
\hline Claracrusta catenoides (Homann 1972) & $\vdots$ & & & - & & - & & & $\vdots$ \\
\hline Clavaporella reinae Rácz 1966 & $\vdots$ & & & - & & & & & 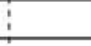 \\
\hline Donezella lutugini Maslov 1929 & $\vdots$ & - & & & & & & & $\vdots$ \\
\hline Ellesmerella permica (Pia 1937) & $\vdots$ & & 回 & & & & & & 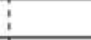 \\
\hline Epimastopora symetrica (Johnson 1951) & 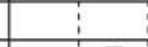 & & & & & & & 口 & \\
\hline Eugonophyllum johnsoni Konishi and Wray 1961 & 口 & $\mathbf{\square}$ & - & & & & & & \\
\hline Eugonophyllum mulderi Rácz 1966 & 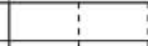 & & - & - & & & & a & \\
\hline Fourstonella fusiformis (Brady 1876) & & & & - & & & & & \\
\hline Fourstonella? johnsoni (Flügel 1966) & & & & & & - & & & \\
\hline Gyroporella dissecta (Chuvashov 1974) & & & $\mathbf{a}$ & & & & & & \\
\hline Gyroporella? prisca Kochansky-Devidé 1970 & & $\mathbf{a}$ & : & & & & & & \\
\hline Herakella paradoxa Kochansky-Devidé 1970 & & - & & & & & & & \\
\hline Hikorocodium kuramotoi Nakamura 1994 & - & & & & & & & & \\
\hline Hikorocodium? sp. & & & & & - & & & & \\
\hline Ivanovia tenuisima Khvorova 1946 & ; & & - & - & & & & & \\
\hline Kasimophyllum demuesensis n. gen., n. sp. & : & & & & $\mathbf{E}$ & & & & \\
\hline Macroporella ginkeli Rácz 1966 & 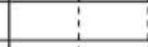 & & & - & & & & & \\
\hline Palaeoberesella lahuseni (von Möller 1879) & 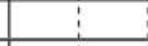 & - & & & & & & & $\vdots$ \\
\hline Pelayella multiporosa n. gen., n. sp. & 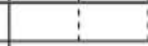 & & & - & & & & & $\vdots$ \\
\hline Penella pongaensis $\mathrm{n}$. gen., $\mathrm{n} . \mathrm{sp}$. & 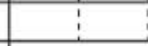 & & & - & & & - & a & 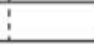 \\
\hline Pseudokomia cansecoensis Rácz 1966 & $i$ & - & & & & & & & $\vdots$ \\
\hline Pseudovelebitella simplex (Kochanky-Devidé 1970) Mamet \& Roux 1978 & $\vdots$ & 量 & 田 & & & & & & $\vdots$ \\
\hline "Pseudogyroporella" annulata Ishijima, Ozaki \& Nakamura 1971 & $i$ & & & - & & & & & 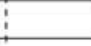 \\
\hline Stacheia marginuloides Brady 1876 & : & & & & & & & & 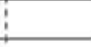 \\
\hline Tubiphytes obscurus Maslov 1956 & 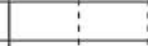 & & & & & $\mathbf{E}$ & & - & 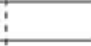 \\
\hline Ungdarella uralica Maslov 1956 & $\begin{array}{c} \\
\end{array}$ & - & & & & & & & 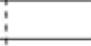 \\
\hline Ungdarellita articulata n. gen., n. sp. & : & & & & & & & & $\vdots$ \\
\hline Uraloporella variabilis Korde 1950 emend. Mamet \& Villa 1995 & 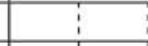 & $\mathbf{\square}$ & & & & & & & 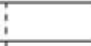 \\
\hline "Vermiporella" hispanica Rácz 1966 & 7 & & & & & & & $\mathbf{\square}$ & \\
\hline Zaporella cantabriensis Rácz 1966 & $\mathbf{a}$ & & & - & & & & & \\
\hline
\end{tabular}

Table 3. Stratigraphic distribution of the algae described in this paper. Absence of species of late Kasimovian age is due to unfavourable facies in the Dorogomilovian strata from the area investigated.

associated Paleosiphonocladales were characteristic of a restricted calm milieu and Archaeolithophyllum, of more agitated waters. He also postulated that algal assemblages were stratigraphically useful, a potential that has not been confirmed.

Donezella mud-mounds were described by Riding (1979), Bowman (1979), Eichmüller and Seibert (1984), and Eichmüller (1985). While Riding favored extensive reworking of the thalli, Eichmüller proposed an alternative bindstone-bafflestone effect. The associated biota in shallow platform surrounded by pelagic sediments yielded Petschoriaphylloids in low energy, Komia in intermediate energy and Archaeolithophyllum in high energy environments.
Rácz (1966a, 1984) felt that Donezella had a bafflingtrapping action, an opinion shared by Dingle et al. (1993) and Hensen et al. (1995). Sedimentological problems connected to Donezella are summarized in Della Porta et al. (2002) and Della Porta (2003).

Upper Carboniferous algal-bryozoan assemblages were described in the Cármenes Syncline (southern Cantabrian Mountains) by Dingle et al. (1993). From the same region, Donezella - Anthracoporellopsis associated with worm tubes and microbes are reported by Samankassou (2001). The red Archaeolithophyllum and the green Donezella acted as bafflestones associated with encrusting bryozoans. Cementstones were commonly produced by the Donezella-bryozoan associations. 
Riding (1979) and Dingle et al. (1993) noted that algae constituted "only" $5-20 \%$ of the mud-mound, thus were unable to produce a bafflestone. However as early as 1962, Dunham documented that branching thalli could form stable boundstones. In our opinion, rocks containing 15\% of branching thalli are probably in situ (bafflestone, bindstone) while rocks composed of $>20 \%$ thalli are formed by hydrodynamically-transported fragments.

Barba Regidor (1998) described two types of carbonate mounds in the Cantabrian Zone: the Archaeolithophyllum/Ungdarella bindstones/bafflestones and the Beresella bafflestones. These floral elements can be associated with Palaeoaplysina (see Antoshkina, 1998), a hydrozoan (?) referred to phylloid algae plates (Davies and Nassichuk, 1973; Kiessling et al., 1999), sponges (Bourque et al., 1995), bryozoans (Ernst, 2000), chaetetids (Stanton et al., 1994) and microbial structures (Riding, 2000; Riding and Awramic, 2000). Other biotic associations are fenestelloidTubiphytes cementstones, red-green algal-calcisponge cementstones and siliceous sponge-bryozoan-Archaeolithoporella cementstones.

Minwegen (2001) recognized in the Carboniferous succession of northern Spain a number of bioconstructions dominated by metazoans, algae or pelmatozoans. Metazoan-dominated buildups are: 1) Beresellidae-chaetetids mounds, 2) chaetetids biostromes, 3) Syringopora- chaetetids reef-mounds, 4) rugose corals, and 5) sponge-algal meadows. Algal constructions are characterized by the abundance of: 6) Petschoria-Donezella, 7) phylloid algae, 8) Anthracoporella, and 9) Archaeolithophyllum. Pelmatozoans mounds are: 10) undiversified dominated by pelmatozoans, or 11) diversified associated with bryozoans, brachiopods, etc. A bit surprising is the lack of recognition of algal encrusters like Claracrusta-Berestoria that stabilize Donezella mounds and the Beresellidae-chaetetids association. Also lacking is the role of Tubiphytes, which is an enigmatic microproblematic fossil.

Della Porta et al. (2002, 2003) and Della Porta (2003) describe in great detail the sedimentology of a carbonate platform/ramp in the Sierra del Cuera, with extensive microbial boundstones. Analysis of Donezella accumulations (Della Porta et al., 2002) suggest that this organism was able to thrive over a large depth range, which led these authors to think that either Donezella did not belong to the green calcareous algae or, alternatively, the Sierra del Cuera depositional system was affected by particular paleo-oceanographic conditions that extended the euphotic zone below the average depth.

\section{TAXONOMY}

The material described below is held in the collections of the Département des Sciences de la Terre et de l'Environnement, Faculté des Sciences, Université Libre de Bruxelles. Specimens are labelled U. of M., for the University of Montreal where the thin sections were made.

PHYLLUM CHLOROPHYCOPHYTA Papenfuss 1946 Genus Anatolipora Konishi 1956

\section{Anatolipora cantabriensis n. sp.}

Fig. 4, 7 e

Origin of name: From the Cantabrian Mountains.

Holotype: Figure 7 e. Repository number: U. of M. 823/13.

Diagnosis: Simple tapening pores with slightly irregular oblique arrangement.

Description: Thallus (cortex and medula) continuous, cylindrical. Diameter, around $400 \mathrm{m \mu}$. Medula, $170 \mathrm{m \mu}$. Cortex, 100$130 \mathrm{~m} \mu$, perforated by numerous, regular, ploiophore pores with oblique, irregular insertion. Pores are about $15 \mathrm{~m} \mu$ thick with interpores of 20-25 mu. There are 24-27 pores per linear millimeter. The taxon belongs to the Salpingoporellinae. See idealized sections at Figure 4.

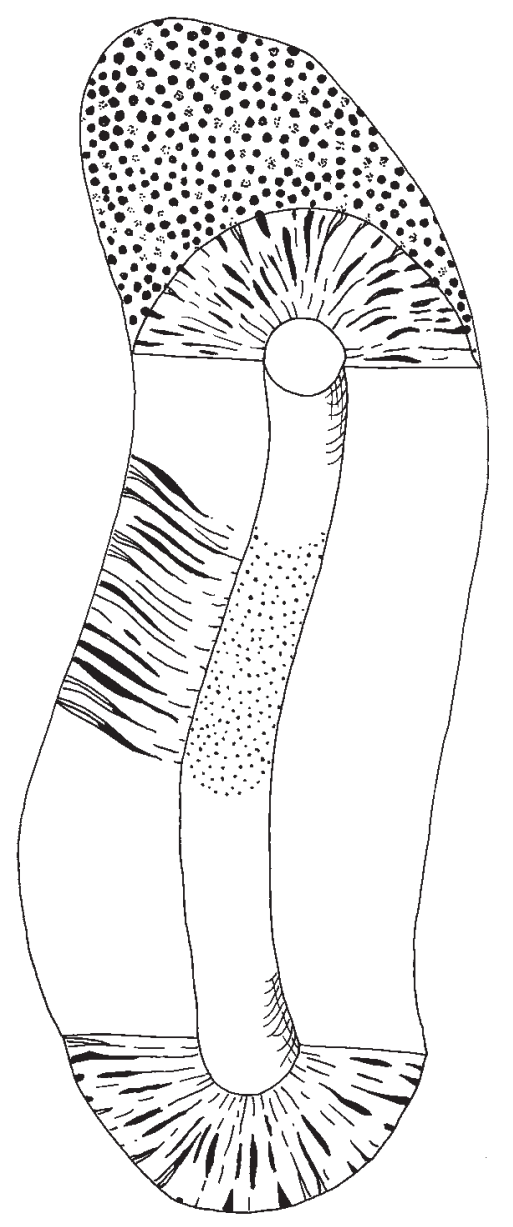

Figure 4. Idealized cross-oblique and longitudinal sections of Anatolipora cantabriensis $\mathrm{n}$. sp. diameter of thallus around $400 \mathrm{m \mu}$. 
Comparison: Differs from Anatolipora carbonica, the type of the genus, by the very regular (non-twisted) thallus, the greater number of pores per linear millimeter and the slight irregular disposition of the branches. Note that the original drawing of Konishi is somewhat idealized (Mamet, 2002).

Stratigraphic distribution and range: Known from the Late Moscovian (Miachkovian) of the Picos de Europa Formation (Fusulinella Zone). The highest recorded occurrence of Anatolipora is Namurian and cantabriensis extends the range into the Moscovian. The holotype is derived from the upper part of the Picos de Europa Formation (sample BM-11, Myachkovian) at Las Llacerias section, associated with algal-rich bafflestones and grainstones. The most prolific algae are Anchicodium, Anthracoporella, Beresella, Donezella, Fourstonella, Hikorocodium, Komia, Pseudokomia, Tubiphytes and Ungdarella.

Genus Anchicodium Johnson 1946

\section{Anchicodium funile Johnson 1946 sensu Torres and Baars 1992}

Fig. $11 \mathrm{e}$

1946 Anchicodium funile Johnson, OD; 1100, pl.2, fig. 3; pl. 3 , fig. 4 ; pl.7, fig. 1 .

1974 Anchicodium funile Johnson; Chuvashov, 17, pl. 2, figs. $1,2$.

1992 Anchicodium funile Johnson; Torres and Baars, 675-677, fig. 1/1-6.

Description: Thallus grossly cylindrical, small (300-600 mu) with central stalk and irregular long and short branches (diameter 15-20 $\mathrm{m} \mu$ ) forming a twig-like structure.

Stratigraphic distribution and range: From the Late Carboniferous (Virgilian) to the Early Permian (Asselian). Observed in Spain in the upper part of the Picos de Europa Formation (sample BM-12, Myachkovian) at Las Llacerias section. Considered as a central North American flora, but should be extended to the Paleotethys.

\section{Genus Anthracoporella Pia 1920}

\section{Anthracoporella vicina Kochansky and Herak 1960}

Fig. 9 g-j, Fig. 10 c-f

1960 Anthracoporella vicina Kochansky and Herak, OD; 69, pl.1, figs. 1-5.

1964a Anthracoporella vicina Kochansky and Herak; Kochansky-Devidé, pl. 3, figs. 2-3.

1966 Anthracoporella vicina Kochansky and Herak; Kochansky-Devidé and Ramovš, 16, pl. 6, figs. 1-4.

1970 Anthracoporella vicina Kochansky and Herak; Kochansky-Devidé, 212, pl. 22, fig. 4.

1971 Anthracoporella vicina Kochansky and Herak; Ramovs̆, 1387, pl.1, fig.3.
1978 Anthracoporella vicina Kochansky and Herak; Ramovs̆, pl. 6, fig. 1.

2000 Anthracoporella vicina Kochansky and Herak; Granier and Grgasovic, 15-16, figs. 2-3.

2001 Anthracoporella sp.; Minwegen, pl. 12, figs. 3-6.

2003 Anthracoporella vicina Kochansky and Herak; Khodjanyazova and Mamet, pl. 3, figs. 21, 28.

Description: Thallus important, ramose, sometimes centimetric in size. Medula occupying $4 / 5$ of the thallus, hence a thin cortex. Pores numerous, regular, very thin $(25 \mathrm{m \mu})$. Interpores twice the pore diameter.

Stratigraphic distribution and range: Paleotethyan flora. Reported from the "Uralian"-Kasimovian of Yugoslavia. In Spain, abundant in the upper part of the Carboniferous (upper Moscovian- lower Kasimovian). It has been recorded from the Las Llacerias section, where it occurs at the upper part of the Picos de Europa Formation and the lower-middle part of the Las Llacerias Formation (samples BM-12, BM-52, BM-72).

\section{Anthracoporella spectabilis Pia 1920}

Fig. 7 a-d

For 85 illustrated references of the taxon, see Homann (1972: 189-191) and update in Granier and Grgasovic (2000: 12-15). Add to the list:

1984 Anthracoporella spectabilis Pia; Saltovskaya, pl. 31, figs. 1-3.

1985 Anthracoporella sp.; Mu, pl. 14, figs. 7-8.

1993 Anthracoporella spectabilis Pia; Perret, pl. 13, fig. 16.

1994 Anthracoporella spectabilis Pia; Nakamura, 15, pl. 9, figs. 7-12.

1994 Anthracoporella spectabilis Pia; Fontaine et al., pl. 5, fig. 2.

1994 Anthracoporella yowarensis Nakamura, OD, 16-17, pl. 10, fig. 1; pl. 11, figs. 1-4.

1995 Anthracoporella spectabilis Pia; Pajic and Filipovic, pl. 51, figs. 2-5.

2001 Anthracoporella spectabilis Pia; Minwegen, pl. 12, figs. 1-2.

2001a Anthracoporella spectabilis Pia; Vachard et al., 385-387, fig. 12/1-10.

2002 Anthracoporella spectabilis Pia; De Castro, 3-12.

2002 Anthracoporella spectabilis Pia; Mamet, pl. 3, figs. 1-2.

2003 Anthracoporella spectabilis Pia; Khodjanyazova and Mamet, pl. 3, fig. 24.

Description: Thallus cylindrical, large, plurimillimetric, bifurcated. Branches 30-50 mu, usually $40 \mathrm{~m} \mu$, aspondyl, ramified once. Wall (100-150 mu), yellowish, of iron-rich calcite.

Discussion: De Castro (2002), Granier and Hofmann (2003), Mu et al. (2003) have recently questioned the dasycladale affinity of Anthracoporella spectabilis on the presence of calcified sheaths and perforated (?) material apparently growing in the stem. However, these characters appear to be secondary features developed after the decay of the alga, the stem being filled by bacterial (?) 
micritic material. This hypothesis has been proposed again by Granier and Hofmann (2003) and by Mu et al. (2003). These authors compare the irregular "pores" to codiacean "filaments" (e. g. Garwoodia). Remnants of medular filaments are also reported which would discard a dasycladale affinity. In the Spanish material, although abundant and well preserved, the central cavity does not disclose the presence of medular tubes and their existence ought to be corroborated by further studies. The same holds true for the Carnic Alps material studied by Samankassou (2002).

Stratigraphic distribution and range: Cosmopolitan. MidCarboniferous to mid-Permian. Reports of the genus in the Devonian (Vachard et al., 2001a) are due to confusion with other dasycladales (e.g. Couvinianella). The drawing (A) of an "atypical" Anthracoporella is indeed very atypical. Forms the Anthracoporella Community of Flügel (1977, p. 322 and 332). In Spain it has been recorded from the Picos de Europa Formation (upper part) and the Las Llacerias Formation at the Las Llacerias section (samples BM-12, BM-52, BM-72, BM-76).

\section{Anthracoporellopsis machaevii Maslov 1956}

Fig. 10 g-h

1956 Anthracoporellopsis machaevii Maslov, OD; 62, pl. 13, fig. 3,4.

1979 (non) Anthracoporellopsis machaevii Maslov; Muromtseva, 91, pl. 1, fig. 3, 8-10.

1964 (?) Anthracoporellopsis machaevii Maslov; Chanton, 565, pl. 17, fig. 3-4.

1968 (non) Anthracoporellopsis machaevii Maslov; Pelhate, 901, pl. 32, fig. 15.

1969 (non) Anthracoporellopsis machaevii Maslov; Pelhate, 6768, pl. 6, figs. 74-76.

1974 (pars) Donezella lunaensis Rácz; Chuvashov, 33, pl. 20, fig. 1-2 (non 3-4).

1975 Anthracoporellopsis machaevii Maslov; Mamet and Roux, 264, pl. 13, figs. 9-11.

1979a Anthracoporellopsis aff. machaevii Maslov; Mamet et al., 360, pl. 3, fig. 16.

1985 Anthracoporellopsis machaevii Maslov; Mamet and Pinard, pl. 1, fig. 15.

1987 Anthracoporellopsis machaevii Maslov; Shuisky, pl. 15, fig. 12.

1987 Anthracoporellopsis machaevii Maslov; Mamet et al., 23, pl. 10, figs. 7-8; pl. 11, figs. 4-5.

1988 Anthracoporellopsis machaevii Maslov; Ivanova and Bogush, pl. 15, fig. 16.

1988 Anthracoporellopsis machaevii Maslov; Ivanova, pl. 2, fig. 9.

1988 Anthracoporellopsis machaevii Maslov; Deloffre, pl. 1, figs. 25-26.

1989 Anthracoporellopsis machaevii Maslov; Skompski et al., pl. 2, fig. 4-7.

1989 Anthracoporellopsis machaevii Maslov; Vachard et al., 706, pl. 1, fig. 6.

1990 Anthracoporellopsis machaevii Maslov; Bogush et al., pl. 10, figs. 5-7.
1991 Anthracoporellopsis machaevii Maslov; Vachard and Beckary, 324, pl. 2, fig. 2.

1991 Anthracoporellopsis machaevii Maslov; Vachard and Tahiri, pl. 4, figs. 7-8.

1991 Anthracoporellopsis machaevii Maslov; Mamet, pl. 3, fig. 1.

1991 Anthracoporellopsis machaevii Maslov; Riding, pl. 3, fig. a.

1993 Anthracoporellopsis machaevii Maslov; Chuvashov et al., pl. 12, fig. 5 .

1995 (?) Anthracoporellopsis machaevii Maslov; Pajic and Filipovic, pl. 48, figs. 4-5.

1996 Anthracoporellopsis machaevii Maslov (pars); Skompski, 225-226, pl. 11, figs. 1-9; pl. 12, figs. 2-6 (non 1).

1996 Anthracoporellopsis machaevii Maslov; Vachard and Maslo, pl. 2, figs. 10-13.

1999 Anthracoporellopsis machaevii Maslov; Sebbar and Mamet, pl. 2, fig. 6.

2000 Anthracoporellopsis machaevii Maslov; Mamet and Stemmerik, pl. 3, figs. D-E.

2002 Anthracoporellopsis machaevii Maslov; Mamet, pl. 1, fig. 7 .

Description: Very irregular Anthracoporellopsis with an external diameter of 200-400 mu. Cortex 30-60 mu. Pores simple, disposed in irregular directions (5-8 $\mathrm{m} \mu$ in diameter).

Stratigraphic distribution and range: Cosmopolitan (Mamet, 1992). Rare in Visean, common in Middle and late Carboniferous (Moscovian, Gzhelian). Reported as late as Early Permian in the Urals. It has been recovered (uncommon) in Spain from upper Moscovian (Myachkovian) beds from the Las Llacerias section (upper part of the Picos de Europa Formation, samples BM-12, and BM-25).

Genus Beresella (Makhaev 1937) Maslov and Kulik 1956

\section{Beresella herminae Rácz 1966a}

Fig. 9 a-f, Fig. 10 a-b, k

1966a Beresella herminae Rácz, OD; 93, pl. 1, figs. 1-3.

1980 (?) Beresella herminae Rácz; Buchroithner et al., 23, pl. $4 / 5$, pl. $5 / 6$.

1985 Beresella herminae Rácz; Eichmüller, pl. 9, fig. 7.

1986 Beresella herminae Rácz; Poncet, 189, pl. 2, figs. 1, 2.

1999 Beresella herminae Rácz; Sebbar and Mamet, pl. 2, fig. 2.

2001 Beresella sp.; Minwegen, pl. 4, fig. 1, 5; pl. 6, fig. 8.

2003 Beresella sp.; Della Porta, pl. 6.1.8.

Description: A heavily calcified beresellid, stouter than most representatives of the genus. Diameter 300-400 mu, reaching $500 \mathrm{~m} \mu$. Thick (up to $100 \mathrm{~m} \mu$ ) cortex. Length of clear rings, 25-50 $\mathrm{m} \mu$. Length of dark rings (micritized pores), 70$200 \mathrm{~m} \mu$.

Stratigraphic distribution and range: Western Paleotethyan flora (Mamet, 1992). Late Bashkirian/Moscovian where they 
form bafflestones. The species is usually not as prolific as its counterparts Beresella erecta Maslov and Kulik 1956 and Beresella ishimica Kulik 1964. It has been recorded in Spain from the upper part of the Picos de Europa Formation at Las Llacerias section. Beds of late Moscovian (Myachkovian) age, samples BM-12, BM-16.

Genus Clavaporella Kochansky and Herak 1960

\section{Clavaporella reinae Rácz 1966b.} Fig. $11 \mathrm{f}$

1966b Clavaporella reinae Rácz, OD; 253, pl. 1, figs. 2-7; pl. 2, fig. 6.

1987 Clavaporella reinae Rácz; Mamet et al., 44, pl. 14, figs. 1-11; pl. 15, figs. 1-7.

1988 Clavaporella reinae Rácz; Chuvashov and Anfimov, 6667, pl. 28, figs. 5-8.

2003 Clavaporella reinae Rácz; Khodjanyazova and Mamet, pl. 3, figs. 14-15.

Description: Thallus segmented, ovoid to conical. Maximum diameter 1000-1700 mu. Upper part of the segment contains the verticillated radiating pores. Such segments reach 500-700 mu. Central part subcylindrical (300-700 $\mathrm{m} \mu)$. Pore diameter 40-60 $\mathrm{m} \mu$, increasing towards the periphery (up to $100 \mathrm{~m} \mu$ ). Vestibule present.

Stratigraphic distribution and range: Originally reported by Rácz from the Middle Moscovian ("Calcareous Zone IV"). It has been recorded in Spain from the Las Llacerias Formation, Las Llacerias section, sample BM-72, lower Kasimovian (Kreviakinian)]. Belongs to the Orthriosiphonoides flora (Mamet, 1992).

Genus Donezella Maslov 1929

\section{Donezella lutugini Maslov 1929}

Fig. $10 \mathrm{j}$

To the 24 references cited by Mamet et al. (1987), add the following:

1980 (non) Donezella lutugini Maslov; Buchroithner et al., 25, pl. 2/5, pl. 5/7-9.

1983 Donezella lunaensis Rácz; Berchenko, pl. 85, fig. 13.

1983 (non) Donezella lutugini Maslov; Berchenko, pl. 86, figs. 1-4.

1985 Donezella lunaensis Maslov; Eichmüller, pl. 9/9, pl. $14 / 1$.

1985 Donezella lutugini Maslov; Skipp et al., pl. 7, figs. $1,6$.

1986 Donezella lutugini Maslov; Groves, 484, figs. 66/11-13.

1991 Donezella lutugini Maslov; Riding, pl. 2, fig. 1.

1992 (non) Donezella cf. lutugini Maslov; Vachard and Berkhli, pl. 4, fig. 18.

1993 Donezella lutugini Maslov; Chuvashov et al., pl. 12, figs. 1-2.

1995 Donezella lutugini Maslov; Pajic and Filipovic, pl. 45, fig. 4 .
1995 Donezella lunaensis Rácz; Pajic and Filipovic, pl. 32, fig. 11, pl. 46, figs. 1-3.

1996 Donezella lutugini Maslov; Proust et al., pl. 1, fig. 1; pl. 2, figs. 1-8.

1996 Donezella lunaensis Rácz; Proust et al., pl. 1, fig. 4; pl. 3, fig. 1-6.

1996 Donezella sp.; Proust et al., pl. 3, figs. 7-9.

1996 Donezella lutugini Maslov; Vachard and Maslo, pl. 2, fig. 7.

1996 Donezella lunaensis Rácz; Vachard and Maslo, pl. 2, figs. 8-9.

1996 Donezella lutugini Maslov; Sebbar and Mamet, pl. 2, figs. 3,6 .

1997 Donezella sp.; Harris et al., fig. 9/3.

1997 Donezella lutugini Maslov; Harris et al., fig. 9/1, 4.

2000 Donezella lutugini Maslov; Mamet and Stemmerik, figs. $5 / \mathrm{C}, \mathrm{D}, \mathrm{E}$

2001 Beresella sp.; Minwegen, pl. 7, figs. 3-4.

2002 Donezella sp.; Della Porta et al., fig. 3/A, C, E; pl. 26, fig. 5,6 .

2002 Donezella lutugini Maslov; Mamet, pl. 1, fig. 5.

2003 Donezella sp.; Della Porta, fig. 3.4 K, M; fig. $4.4 \mathrm{~K}$; fig. 4.5 A, D; pl. 4.1, fig. 5; pl. 5.6, fig. 1; pl. 5.7, fig. 3 ; pl. 6.1, figs. $1,5-7$; pl. 6.2, figs. 6-9, 11; pl. 6.3, figs. 2-7.

2003 Donezella lutugini Maslov; Khodjanyazova and Mamet, pl. 2, fig. 16 .

Description: Thallus erect, a highly branching tuft. Considerable dimension variations depending on the position of the thin-section cut. External diameter ranges from 65 to $260 \mathrm{m \mu}$ and can reach $450 \mathrm{~m} \mu$. Perforated cortex, 12-60 $\mathrm{m} \mu$. Pores usually micritized forming irregular "dark bands". Thin external mucilagineous coating, now transformed in cement. Spacing of the pseudo-partitions proportional to the external diameter.

Stratigraphic distribution and range: While beresellids are considered green algae forming bafflestones, the taxonomic position of their "cousin" Donezella, in spite of the same pore morphology, is still controversial (see Della Porta et al., 2002). A common cosmopolitan taxon (Mamet, 1992) from the Bashkirian to the end of the Carboniferous. This paper records an occurrence of Donezella lutugini in the upper part of the Picos de Europa Formation at Las Llacerias section, sample BM28, uppermost Moscovian, closely below the Moscovian/ Kasimovian transition beds.

Genus Dvinella Khvorova 1949

\section{Dvinella comata Khvorova 1949}

Fig. $8 \mathrm{q}$

To the 20 references of Granier and Grgasovic (2000: 50), add: 2000 Dvinella comata Mamet and Stemmerik, pl. 6, K-L.

Description: Strongly calcified beresselid alga. External diameter 200-250 mu. Thickness of cortex 50-75 mu. Pores numerous, forming a triangular "dark band". Spacing of these bands rather uniform. 
Stratigraphic distribution and range: Same as Beresella. The two genera are usually associated in meadows and bioconstructions.

Genus Epimastopora Pia 1922 emend. Roux 1979

\section{Epimastopora symetrica (Johnson 1951)} Fig. $8 \mathrm{p}$

To the 24 references of Granier and Grgasovic (2000), add:

1991 Epimastopora symetrica (Johnson); Riding, 381, pl. 3, figs. n-o.

2001 Globuliferoporella piai (Kordé 1951) n. comb.; Vachard and Krainer, pl. 3, fig. 8 .

Description: An important plurimillimetric Epimastopora but fragile and usually encountered in small fragments. Cortex, 150$300 \mathrm{~m} \mu$. Pores, double-gourd shaped, 75-150 mu in diameter.

Stratigraphic distribution and range: Cosmopolitan, known from the Middle Carboniferous to the Early Permian. This paper records an occurrence from the upper member of the Puentellés Formation at the Berodia-II section, sample BM-123, lower Gzhelian.

Genus Gyroporella (Gümbel 1872) Benecke 1876

\section{Gyroporella dissecta Chuvashov 1974}

Fig. $8 \mathrm{n}$

1974 Gyroporella dissecta Chuvashov, OD; 29, pl. 15, figs. 1-6.

1979 Gyroporella dissecta Chuvashov; Zadorodnjuk, pl. 2, fig. 2.

1982 Gyroporella dissecta Chuvashov; Mu, 226, pl. 6, figs. 7-10.

1993 Gyroporella dissecta Chuvashov; Chuvashov et al., pl. 14, figs. 15-17.

2000 Gyroporella dissecta Chuvashov; Granier and Grgasovic, 72.

2001 Gyroporella dissecta Chuvashov; Vachard and Krainer, pl. 5 , fig. 4 .

Description: Elongated club-shaped thallus and similarly shaped medula (175-250 mu). Diameter rather small compared to other representatives of the genus. Pores aspondyl, vesiculiferous, 75-150 $\mathrm{m} \mu$ at the base of the cortex and twice as large at the surface.

Stratigraphic distribution and range: The species is reported from the Upper Carboniferous to the Early Permian. Our Spanish material comes from the uppermost part of the Picos de Europa Formation at the Las Llacerias section, sample BM-46, lowest Kasimovian.

Note: Gyroporella needs a formal taxonomic emendation. Indeed, the status of Pseudogyroporella (taxonomically invalid) and of Mizzia has to be clarified.

\section{Gyroporella (?) prisca Kochansky-Devidé 1970}

Fig. 8 a-g.

1964a Gyroporella prisca Kochansky-Devidé, OD; pl. 1, fig. 3 (invalid, no description).

1970 Gyroporella prisca Kochansky-Devidé, 14-15, pl. 1, fig. 4; pl. 4, figs. 2-6; pl. 5, figs. 1-7; pl. 6, figs. 1-2, 6; pl. 7, fig. 1 (first valid description).

1982 Gyroporella prisca Kochansky-Devidé; Milanovic, 2122 , pl. 8 , fig. 6 .

Description: Thallus very large (diameter up to $4 \mathrm{~mm}$ ) with a prominent unsegmented medula and a comparatively thin cortex. Thick pores, heart-shaped in transverse section.

Stratigraphic distribution and range: Occidental Paleotethyan flora. Reported from the Late Moscovian to the Kasimovian in Yugoslavia. In our material, present in shallow-water facies of the uppermost part of the Picos de Europa Formation at the Las Llacerias section, sample BM-46, lowest Kasimovian.

Genus Pseudogyroporella Endo 1959, invalid

\section{"Pseudogyroporella" annulata Ishijima, Ozaki and Nakamura 1971 \\ Fig 8 o}

1971 Pseudogyroporella annulata Ishijima, Ozaki and Nakamura, OD; p. 112-113, pl. 5, fig. 4B; pl. 6, figs. 7-11.

Description: Thallus club-shaped, small, diameter inferior to one millimeter with external annulations. Pores aspondyl, important, vesiculiferous, perpendicular to the stem and in regularly-spaced whorls.

Stratigraphic distribution and range: Originally described from the Early Permian of Japan. Recorded in Spain at the top of the Picos de Europa Formation, Las Llacerias section, sample BM-63, lower Kasimovian.

Note: As previously indicated, a taxonomic revision of Gyroporella and related genera is needed. The Spanish species cannot be transferred to the Triassic Gyroporella annulata (Schafhautl 1853) Gümbel 1872 and the invalid "Pseudogyroporella" is tentatively used.

Genus Herakella Kochansky-Devidé 1970

Herakella paradoxa Kochansky-Devidé 1970

Fig. $11 \mathrm{a}, \mathrm{b}$

1970 Herakella paradoxa Kochansky-Devidé, OD; 22-25, pl. 5, fig. 1 ; pl. 12, figs. 5-9; pl. 13, figs. 1-11; pl. 14, figs. 1-13; pl. 15, fig. 11-2.

1982 Herakella paradoxa Kochansky-Devidé; Milanovic, 23, pl. 10 , fig. 5 .

1988 Herakella paradoxa Kochansky-Devidé; Deloffre, pl. 6, fig. 13. 1990 (?) Herakella paradoxa Kochansky-Devidé; Bogush et al., pl. 14, fig. 1.

2000 Herakella sp.; Forke and Samankassou, pl. 33, figs. 1-6. 
2001 Herakella paradoxa Kochansky-Devidé; Vachard and Krainer, pl. 5, fig. 1.

2003 Herakella paradoxa Kochansky-Devidé; Khodjanyazova and Mamet, pl. 3, figs. 25-27.

Description: Cortex cylindrical, segmented. Crescentic segments. Diameter, 1000-2000 mu. Medula continuous, cylindrical. Diameter 300-800 mu, average $500 \mathrm{~m} \mu$. Five to ten metaspondyl pores in bundles perforating the cortex at an angle of $20^{\circ}-40^{\circ}$.

Stratigraphic distribution and range: The taxon is reported in the Paleotethys from the Late Moscovian to the Kasimovian. Our Spanish material comes from the upper part of the Picos de Europa Formation at the Las Llacerias section, sample BM-28, uppermost Moscovian (upper Myachkovian).

\section{Genus Hikorocodium Endo 1951}

\section{Hikorocodium kuramotoi Nakamura 1994}

Fig. $11 \mathrm{c}$

1994 Hikorocodium kuramotoi Nakamura, OD; 38-39, pl. 22, figs. 6-7.

Description: Thallus nodular, around $2 \mathrm{~mm}$ in all specimens. Pith-like central cavity surrounded by a micritized cortex perforated by numerous anastomosed constricted tubes. Tubes thin, $20 \mathrm{~m} \mu$ at departure from central cavity and thicker towards the periphery.

Stratigraphic distribution and range: The Hikorocodium flora is usually connected to Permian shallow water carbonates, although Nakamura described H. kuramotoi from the Carboniferous of Japan (Yowora). In Spain this taxon is observed in the upper part of the Picos de Europa Formation, Las Llacerias section, sample BM-12, upper Moscovian (Myachkovian). A probable Hikorocodium (Hikorocodium? sp.) is illustrated in Fig. $11 \mathrm{~g}$; the latter comes from a Khamovnikian bed of the Las Llacerias Formation, sample BM-74B.

\section{Genus Macroporella Pia 1912}

\section{Macroporella ginkeli Rácz 1966a} Fig. $7 \mathrm{~g}$

1966a Macroporella ginkeli Rácz, OD; 98-99, pl. 6, figs. 1-3. 1981 Macroporella ginkeli Rácz; Rauzer-Chernoussova and Koroljuk, 164, pl. 3, figs. 6-7.

1988 Macroporella ginkeli Rácz; Chuvashov and Anfimov, 6465, pl. 27, figs. 1-2.

1993 Macroporella ginkeli Rácz; Chuvashov et al., pl. 13, fig. 1.

2003 Macroporella ginkeli Rácz; Khodjanyazova and Mamet, pl. 3, fig. 20 .

Description: Thallus cylindrical with a diameter ranging from 1.5 to $2 \mathrm{~mm}$. Important (50-60\% of the thallus) unsegmented medula. Slightly inclined $\left(15^{\circ}\right)$ branches without ramifications and with a progressive diameter increase towards the outer part of the cortex.

Stratigraphic distribution and range: Originally reported from the Moscovian. Known range in the Paleotethys: Moscovian-Kasimovian. Observed in the top of the Picos de Europa Formation sample BM-63 (lower Kasimovian), Las Llacerias section.

Genus Palaeoberesella Mamet and Roux 1974

\section{Palaeoberesella lahuseni (von Möller 1879)} Fig. $8 \mathrm{~h}$

1879 Nodosinella lahuseni von Möller, OD; 75, pl. 5, figs. 6ab, 7 .

1948 Nodosinella lahuseni von Möller; Rauser-Chernoussova, figs. 4-9.

1972 Kamaena lahuseni (von Möller); Mamet and Rudloff, 87, pl. 5, figs. 13-14.

1973 Anthracoporellopsis sp.; Ivanova, pl. 10, fig. 2.

1974 Palaeoberesella lahuseni (von Möller); Mamet and Roux, 144, 148, pl. 2, figs. 20-28; pl. 3, figs. 1-29; pl. 4, figs. 1-17.

1975 Nodosinella? scalaris Malakhova, OD; 85-86, pl. 9, fig. 5-11.

1976 Palaeoberesella lahuseni (von Möller); Mamet, pl. 6, fig. 2; pl. 56, fig. 3; pl. 59, fig. 3.

1978 Palaeoberesella lahuseni (von Möller); Jansa et al., 1434, pl. 1, figs. 15, 18.

1979 Paleoberesella (sic); Radionova, pl. 1, fig. 7.

1979 Paleoberesella lahuseni (sic) (von Möller); Radionova, pl. 1, figs. 8-10.

1981 Palaeoberesella lahuseni (von Möller); Mamet and Martínez, pl. 2, fig. 1.

1981 Palaeoberesella lahuseni (von Möller); Vachard, 312314 , pl. 13, fig. 2.

1983 Palaeoberesella lahuseni (von Möller); Cnudde and Mamet, pl. 1, fig. 5.

1986 Palaeoberesella lahuseni (von Möller); Mamet et al., 30, pl. 12, fig. 9.

1987 Palaeoberesella lahuseni (von Möller); Shuysky, pl. 16, fig. 9.

1988 Palaeoberesella lahuseni (von Möller); Flügel and Kahler, 144, pl. 20, fig. 1.

1988 Palaeoberesella lahuseni (von Möller); Ivanova and Bogush, pl. 7, figs. 2-4.

1990 Palaeoberesella lahuseni (von Möller); Bogush et al., 96-97, pl. 8, figs. 6-11.

1990 Palaeoberesella scalaris (Malakhova); Bogush et al., OD; p. 97, pl. 8, fig. 12.

1991a Palaeoberesella lahuseni (von Möller); Vachard, pl. 5, fig. 2.

1992 Palaeoberesella lahuseni (von Möller); Mamet and Préat, pl. 1, fig. 14.

1993 Palaeoberesella lahuseni (von Möller); Chuvashov et al., pl. 10, fig. 6.

1994 Palaeoberesella lahuseni (von Möller); Vachard and Clement, 306, pl. 2, fig. 5; pl. 3, fig. 4.

1995 Palaeoberesella lahuseni (von Möller); Sanchez-Chico et al., 74, pl. 1, fig. 11; pl. 2, fig. 11. 
1996 Palaeoberesella lahuseni (von Möller); Sebbar and Mamet, pl. 2, fig. 7.

1999 Palaeoberesella lahuseni (von Möller); Mamet et al., pl. 4 , figs. 3-4.

Description: Subcylindrical, long muff, straight or slightly curved. Diameter of calcified cortex, 100-200 mu. Medula composed of a succession of irregular cells (up to 25-30 mu), subcircular to subquadratic. Pores simple, thin, straight.

Stratigraphic distribution and range: Cosmopolitan (Mamet, 1992). Rare in mid-Devonian, then extremely abundant in Visean-Serpukhovian where it forms bafflestones in lagoonal environment. Peters out in Late Carboniferous, where it is replaced by the beresellids. This paper reports its occurrence in sample P-21 (upper Myachkovian), Corisa Formation, Sierra Corisa locality, northern Palencia.

\section{Genus Pelayella n. gen.}

Type species: Pelayella multiporosa n. gen., n. sp.

Origin of name: For the name of the first Asturian king (Pelayo) who received his crown at Covadonga.

Diagnosis: A club-shaped, regular, aspondyl Salpingoporellinae. Thin pores divided in tufts.

Description: Thallus sinuous, cylindrical, unconstricted. Medula continuous, cylindrical. Cortex important, perforated by a multitude of arched aspondyl pores, with slight oblique insertion. Pores enlarge slowly, then divide in a tuft of 5-6 branches.

Comparison: By its morphology, Pelayella is similar to Anatolipora and belongs to the same tribe (Salpingoporellinae). It differs from the latter by the nature of the pore dichotomy.

Stratigraphic distribution and range: Known from the Kasimovian of the Las Llacerias Formation (sample BM-72), Las Llacerias section (vicinity of Covadonga), where it is associated with a very rich flora of Anthracoporella variabilis, A. vicina, Archaelithophyllum delicatum, A. johnsoni, Claracrusta, Cuneiphycus, Epimastopora symetrica, Ivanovia tenuissima, Penella pongaensis, Tubiphytes obscura and Zaporella cantabriensis.

\section{Pelayella multiporosa n. gen., n. sp.} Fig. $11 \mathrm{~d}$

Origin of name: From the multiple pores.

Holotype: Figure 11 d. Repository number U. of M. 728/2

Diagnosis: See the genus.

Description: Thallus cylindrical, club-shaped, sinuous, with a diameter of 900-1000 mu. Medula continuous, 270-300 m Cortex, 300-350 mu. There are 21-24 aspondyl pores per lin- ear millimeter. Pores are very thin, 3-5 mu, with oblique insertion. They enlarge progressively up to two-thirds of their length, then form a tuft of 5-6 (3-5 mu) branches. Due to heavy micritization, the tufts are dissolved and form an epidermic cone that reaches up to $30 \mathrm{~m} \mu$ in diameter.

Stratigraphic distribution and range: See the genus.

Genus Pseudovelebitella Mamet and Roux 1978

\section{Pseudovelebitella simplex (Kochansky- Devidé 1964b) Mamet and Roux 1978 \\ Fig. $8 \mathrm{i}-\mathrm{j}$}

1964b Velebitella simplex Kochansky-Devidé, OD; 136-137, pl. 1, fig. 1, a-h; pl. 2, fig. 1-9.

1964a Velebitella simplex Kochansky-Devidé, 188, pl. 19, fig. 1.

1977 Velebitella sp.; Vachard in Termier et al., 15, pl. 2, fig. 7.

1978 Pseudovelebitella simplex (Kochansky-Devidé); Mamet and Roux, 75.

1985 Velebitella simplex Kochansky-Devidé; Vachard, 273, pl. 2, figs. 5-7.

1988 Pseudovelebitella simplex (Kochansky-Devidé); Deloffre, fig. 12.

2000 Pseudovelebitella simplex (Kochansky-Devidé); Granier and Grgasovic, 147, figs. 24-25 (reproduction of part of Kochansky's material).

2003 Pseudovelebitella simplex (Kochansky-Devidé); Khodjanyazova and Mamet, pl. 3, figs. 22-23.

Description: Diplopore composed of a succession of barrelshaped articles (diameter 500-600 mu). Medula very large and poorly developed "napkin-ring" cortex. Divergent bundles of thin pores, starting from a small vestibule and concentrated in the median part of the articles.

Stratigraphic distribution and range: Belongs to the Paleotethyan flora. Moscovian to Early Permian. Quite scarce in the Asturian material; it occurs in the upper part of the Picos de Europa Formation, samples BM-14 (upper Myachkovian), and BM-46 (lowest Kreviakinian).

GenusVermiporella Stolley 1893 sensu Pia 1927

\section{“Vermiporella" hispanica Rácz 1966b} Fig. $11 \mathrm{~h}$

1966b Vermiporella hispanica Rácz, OD.; 257, pl. 5, figs. 2326.

Description: Thallus millimetric, tubular, irregular, sinuous, ramified. Cortex uniform, much less important than the medula (150-200 $\mathrm{m \mu}$ ), perforated by simple cylindrical branches, perpendicular to the stem $(20-40 \mathrm{~m} \mu)$. Interpore length, half that of the pores.

Note: Vermiporella is an Early Paleozoic Dasyporelleae, abundant in Ordovician-Silurian, that peters out in the Devonian. Its 
presence in the Carboniferous is debatable and the Cantabrian material ought to be transferred to a new genus.

Stratigraphic distribution and range: Rácz reports hispanica from the Late Moscovian. It is also present in the Kasimovian. Our material comes from sample BM-101, upper member of the Puentellés Formation, lower Gzhelian, Berodia-I section.

Genus Uraloporella Kordé 1950

\section{Uraloporella variabilis Kordé 1950 emend. Mamet and Villa 1995}

Fig. $10 \mathrm{i}$

For taxonomy, refer to the 23 references in Granier and Grgasovic (2000: 160-161), and add:

2000 Uraloporella variabilis Kordé; Mamet and Stemmerik, fig. 4, A-I.

2001 Uraloporella variabilis Kordé; Minwegen, pl. 4, fig. 1 (pars), 6-7.

2001 Uraloporella sp.; Minwegen, pl. 6, fig. 8 (pars), pl. 15, fig. 4.

2003 Uraloporella sp.; Della Porta, fig. 3.5. A (pars).

2003 Uraloporella variabilis Kordé; Khodjanyazova and Mamet, pl. 2, fig. 19.

Description: Long, unsegmented, cylindrical thallus with an external diameter ranging from 150 to $600 \mathrm{~m} \mu$. Internal cavity unsegmented. Cortex perforated by "innumerable" micrometric pores (up to one hundred in a single axial section!) The species has been emended from the upper Moscovian (Podolian) of La Huelga beach section, Asturias, where it forms extensive boundstones.

Stratigraphic distribution and range: Reported from the Middle Carboniferous in the Paleotethyan and Arctic realms. Very abundant in the Moscovian, usually associated with beresellids. Similar distribution in Spain. Present material comes from the upper part of the Picos de Europa Formation, sample BM-19 (upper Moscovian, upper Myachkovian), Las Llacerias section.

\section{Genus Zaporella Rácz 1966a}

\section{Zaporella cantabriensis Rácz 1966a}

Fig. 7 h-k

1966a Zaporella cantabriensis Rácz, OD; 102-103, pl. 1, figs. 4-7. 1985 Zaporella cantabriensis Rácz; Eichmüller, pl. 14, fig. 8.

Description: Thallus grossly cylindrical, unbranched. Diameter millimetric $(1.5-5 \mathrm{~mm})$. Cortex thick, medula reduced. Pores simple, undivided, $50 \mathrm{~m} \mu$ in diameter. Interpores of similar magnitude.

Comparison: Our material has fewer and thicker pores than the microfossils illustrated by Rácz and Eichmüller. Note: Granier and Grgasovic (2000) indicate 1964 as the valid date of the genus. The correct date appears to be 1966, when the formal description "became available".
Stratigraphic distribution and range: Quite rare. Previously reported from the Moscovian. Observed in our material from the upper part of the Picos de Europa Formation (sample BM11, upper Moscovian, Myachkovian) and Las Llacerias Formation (sample BM-72, lower Kasimovian, top of Krevyakinian) at Las Llacerias section.

PHYLLUM CHLOROPHYCOPHYTA? Papenfuss 1946 or RHODOPHYCOPHYTA? Papenfuss 1946

Genus Eugonophyllum Konishi and Wray 1961

\section{Eugonophyllum johnsoni Konishi and Wray 1961}

Fig. 12 f-i

For 11 previous references to the taxon, see Flügel and FlügelKahler (1980: 117), and add:

1981 Eugonophyllum johnsoni uralicum Rauzer-Chernoussova and Koroljuk, 160, pl. 1, figs. 1-4.

1982 Eugonophyllum johnsoni Konishi and Wray; Milanovic, 19, pl. 7, figs. 8-9.

1983 Eugonophyllum cf. E. johnsoni Konishi and Wray; Toomey, 170, pl. 21, figs. 7, 11-12.

1987 Eugonophyllum johnsoni Konishi and Wray; Mamet et al., 17-18, pl. 5, figs. 7-12; pl. 6, figs. 1-8; pl. 8, figs. 6-7.

1993 Eugonophyllum johnsoni Konishi and Wray; Vachard et al., pl. 1, fig. 1.

1994 Eugonophyllum johnsoni Konishi and Wray; Nakamura, 35 , pl. 18, figs. 10-12.

1995 "Eugonophyllum " johnsoni Konishi and Wray; Pajic and Filipovic, pl. 50, figs. 8-9.

2001 Phylloid algae (pars); Minwegen, pl. 1, fig. 6.

2003 Eugonophyllum johnsoni Konishi and Wray; Khodjanyazova and Mamet, pl. 4, fig. 10.

Description: Plurimillimetric to pluricentimetric phylloid blade. Thickness 500-1500 mu. External cortex thin, 30-50 mu. Internal cortex 30-100 mu. Utricles 20-60 mu.

Stratigraphic distribution and range: Cosmopolitan. Total range Moscovian to Mid-Permian (same as Ivanovia). In NW Spain, Moscovian and earliest Kasimovian where it proliferates and forms boundstones. Recorded in the Las Llacerias section from the Picos de Europa Formation (sample BM-12, upper Myachkovian, and sample BM-46, lowest Krevyakinian). It has been also recorded from the Corisa Formation in Sierra Corisa locality, northern Palencia (sample P-21, upper Myachkovian).

\section{Eugonophyllum mulderi Rácz 1966a}

Fig. 12 b-e

1966a Eugonophyllum mulderi Rácz, OD; 106, pl. 12, figs. 1-4.

1970 Eugonophyllum mulderi Rácz; Kochansky-Devidé, 10-11, pl. 2, fig. 1.

1978 Eugonophyllum mulderi Rácz; Kulik, 185-186, pl. 1, figs. 4-5.

1980 Eugonophyllum mulderi Rácz; Flügel and Flügel-Kahler, 120, pl. 1, fig. 8 . 
2003 Eugonophyllum mulderi Rácz; Khodjanyazova and Mamet, pl. 4, fig. 11.

Description: Small, irregular, phylloid blade. Thickness 200$450 \mathrm{~m} \mu$. Medula sometimes reduced to less than $200 \mathrm{mu}$. External cortex 30-50 mu, with utricles of the same dimensions.

Stratigraphic distribution and range: Known from the western part of the Paleotethyan Realm. Late Moscovian for Rácz. Extended to the Kasimovian by Kochansky-Devidé and to the Asselian by Khodjanyazova and Mamet. Forms phylloid algae mounds in the Cantabrian Mts. and in Yugoslavia. Present material has been collected from the lowest Kasimovian of the Las Llacerias section (sample BM-47, top of Picos de Europa Formation), the Kasimovian of Demués section (sample BM-276, Demués Formation), and the lower Gzhelian of Berodia-I section (sample BM-105, upper member of the Puentellés Formation).

\section{Genus Ivanovia Khvorova 1946}

\section{Ivanovia tenuissima Khvorova 1946}

Fig. 12 a, j-n

To the 8 references in Mamet et al. 1987, 19-20, add:

1991 Ivanovia tenuissima Khvorova; Riding, pl. 3, fig. f.

1995 Ivanovia tenuissima Khvorova; Pajic and Filipovic, pl. 47, figs. 6-7.

1995 Ivanovia tenuissima Khvorova; Forke, 240, pl. 20, figs. $1-4$.

1996 Ivanovia tenuissima Khvorova; Mamet, pl. 1, fig. 8.

2000 Ivanovia tenuissima Khvorova; Mamet and Stemmerik, fig. 9A.

2003 Ivanovia tenuissima Khvorova; Khodjanyazova and Mamet, pl. 4, fig. 9.

Description: Plurimillimetric to pluricentimetric phylloid blade. Thickness 500 to $1500 \mathrm{~m} \mu$. Cortical zone reduced to $100 \mathrm{~m} \mu$. Angular utricles perpendicular to cortex (15-30 mu).

Note: For a detailed discussion on Ivanovia, refer to Torres (1997).

Stratigraphic distribution and range: Originally created from the Upper Carboniferous of the Moscow Basin. Probable range, Moscovian to mid Permian (Artinskian or younger). In NW Spain, abundant in the Kasimovian and forms mounds associated with Tubiphytes. Present material was collected at Las Llacerias section from the uppermost part of the Picos de Europa Formation (sample BM-47) and Las Llacerias Formation (samples BM-69, BM-70, BM-72), lower Kasimovian (Krevyakinian).

PHYLLUM RHODOPHYCOPHYTA Papenfuss 1946 Genus Fourstonella Cummings 1955

\section{Fourstonella fusiformis (Brady 1876)}

$$
\text { Fig. } 14 \mathrm{e}
$$

1876 Stacheia fusiformis Brady, OD; 114, pl. 8, figs. 12-16.
1955 Fourstonella fusiformis (Brady 1876); Cummings, 7, figs. 4, 5, F-G.

1956 Stacheia fusiformis Brady; Braznikhova, 50, pl. 2, fig. 9; pl. 10, fig. 9 .

1964 Fourstonella fusiformis (Brady 1876); Loeblich and Tappan, C331, fig. 246.

1967 Fourstonella fusiformis (Brady 1876); Eickhoff, 37-38, pl. 3, fig. 5; pl. 4, figs. 6-8.

1977 Fourstonella fusiformis (Brady 1876); Perret and Vachard, 114, pl. 5, fig. 3.

1977 Fourstonella fusiformis (Brady 1876); Mamet and Roux, 222-223, pl. 2, fig. 4.

1978 Fourstonella fusiformis (Brady 1876); Jansa et al., 1436, pl. 1 , fig. 21.

1986 Fourstonella fusiformis (Brady 1876); Skompski, pl. 15, figs. 1-5.

1988 Fourstonella fusiformis (Brady 1876); Ivanova and Bogush, pl. 18, fig. 14.

1989 Fourstonella fusiformis (Brady 1876); Skompski et al., pl. 2, fig. 3.

1990 Fourstonella fusiformis (Brady 1876); Bogush et al., 126-127, pl. 26, fig. 8-9; pl. 27, figs. 1-2.

1995 Fourstonella fusiformis (Brady 1876); Sanchez-Chico et al., 76, pl. 3, figs. 10-11; pl. 4, figs. 9-10.

1996 Fourstonella fusiformis (Brady 1876); Mamet, pl. 3, fig. 1 .

Description: Thallus fusiform, with a regular addition of curvilinear rows that overlap each other. The alga is attached to a central support, usually a (now) dissolved phaeophyte or a sponge megasclere. Overall diameter 400-600 mu and length $600 \mathrm{~m} \mu$ to $1-3 \mathrm{~mm}$. Thickness of interlaminae $10 \mathrm{~m} \mu$. Height of rows, 20-25 mu.

Stratigraphic distribution and range: A widespread and long ranging species observed from the Visean to the Early Permian? Our illustrated Spanish material is from the Kasimovian.

Genus Fourstonella? Cummings 1955 or Cuneiphycus? Johnson 1960

or Efluegelia? (Vachard in Massa and Vachard 1979)

Ramovš and Kochansky-Devidé 1981 nom. corr.

Fourstonella? johnsoni (Flügel 1966) Fig. $14 \mathrm{f}$

1966 Cuneiphycus johnsoni Flügel, OD; 17-19, pl. 2, figs. 1-5.

1969 Cuneiphycus sp. cf. C. johnsoni Flügel; Toomey, 1318, pl. 151, figs. 3-4.

1972 Cuneiphycus johnsoni Flügel; Homann, 165-169, pl. 2, fig. 12.

1974 Cuneiphycus johnsoni Flügel; Chuvashov, 32, pl. 21, figs. 1-8.

1977 Cuneiphycus johnsoni Flügel; Mamet and Roux, 238, pl. 9, figs. 8-11.

1978 Cuneiphycus johnsoni Flügel; Mamet and Roux, 83, pl. 7, figs. 11-12. 
1979 Eflugelia (sic) johnsoni (Flügel); Vachard in Massa and Vachard, 34, pl. 9, fig. 10.

1980 Eflugelia (sic) johnsoni (Flügel); Flügel, pl. 7, fig. 2; pl. 9, fig.1.

1980 Eflugelia (sic) johnsoni (Flügel); Flügel and FlügelKahler, 163-164, pl. 8, figs. 9-10.

1981 Efluegelia johnsoni (Flügel); Ramovs̆ and KochanskyDevidé, 97, pl. 1, fig. 2.

1981 Eflugelia (sic) johnsoni (Flügel); Vachard and Montenat, 60, pl. 9, fig. 1 ; pl. 10, figs. 1-3, 5-6; pl. 12, fig. 10 .

1982 Efluegelia johnsoni (Flügel); Milanovic, pl. 7, fig. 10; pl. 10, fig. 3 .

1983 Eflugelia sp. (sic); Groves, 29-30, pl. 8, figs. 6-9.

1985 Cuneiphycus johnsoni Flügel; Mamet and Pinard, pl. 1, figs. 18-21; pl. 3, fig. 1 .

1986 Fourstonella johnsoni (Flügel); Groves, 488, fig. 8/3-8.

1986 Eflugelia (sic) johnsoni (Flügel); Skompski, 268-269, fig. 6; pl. 10, figs. 1-2.

1987 Cuneiphycus johnsoni Flügel; Mamet et al., 55-56, pl. 28, figs. 5-10.

1987 Eflugelia (sic) johnsoni (Flügel); Chuvashov, pl. 21, fig. 5.

1989 Eflugelia (sic) johnsoni (Flügel); Sebbar and Lys, pl. 1, fig. 7.

1990 Eflugelia (sic) johnsoni (Flügel); Sebbar, pl. 1, fig. 5.

1993 Eflugelia (sic) johnsoni (Flügel); Vachard et al., pl. 2, figs. 6-8.

1993 Eflugelia (sic) johnsoni (Flügel); Chuvashov et al., pl. 12, fig. 14.

1995 Eflugelia (sic) johnsoni (Flügel); Forke, pl. 15, fig. 8.

1996 Eflugelia (sic) johnsoni (Flügel); Vachard and Maslo, pl. 1 , fig. 11.

2001 Eflugelia (sic) johnsoni (Flügel); Vachard and Krainer, pl. 3, fig. 12.

2001a Eflugelia (sic) johnsoni (Flügel); Vachard et al., pl. 18, fig. 17.

2002 Cuneiphycus? johnsoni Flügel(or Fourstonella?); Mamet, pl. 6, fig. 9.

2003 Cuneiphycus? johnsoni Flügel (or Fourstonella?); Khodjanyazova and Mamet, pl. 5, fig. 4.

Description: Thallus attached on a support: shapes vary from hemispheric to "lemon-like". Length up to one millimeter. Laminae of slightly irregular subquadratic cells. Cell height 12-25 $\mathrm{m} \mu$ and width, 10-20 mu. Horizontal cells much thicker $(15 \mathrm{m \mu})$ than vertical partitions $(5 \mathrm{~m} \mu)$.

Discussion: Groves (1986) attributed the morphological variations to the shape of the substrate and questioned the existence of the genus Efluegelia ("Eflugelia" of the literature). The situation is further complicated by the unsolved status of Cuneiphycus, a genus that requires emendation. The disappearance of its type and the obscure relation with Foliophycus does not improve the taxonomic chaos.

Stratigraphic distribution and range: Cosmopolitan and common (Mamet, 1992). Carboniferous/Upper Permian in Eurasia. Our illustrated material is from the Kasimovian as is that of Khodjanyazova and Mamet (2003). It has been collected from the upper part of the Las Llacerias Formation (sample BM-77B, upper Khamovnikian) at Las Llacerias section.

Genus Archaeolithophyllum Johnson 1956

\section{Archaeolithophyllum johnsoni Rácz 1966a}

Fig. 13 c-e

1966a Archaeolithophyllum johnsoni Rácz, OD; 87-88, pl. 9, figs. 1-4.

1986 Archaeolithophyllum johnsoni Rácz; Poncet, 190, pl. 2, figs. 7-8.

Description: Thallus branching, 500-800 mu thick, with poor develpment of small regular perithallic cells $(10-15 \mathrm{m \mu})$. Polygonal hypothallic cells, 60-80 $\mathrm{m} \mu$ in lenght.

Stratigraphic distribution and range: Bashkirian-Moscovian of Spain and Algerian Sahara. Extends probably up to lower Gzhelian in the Picos de Europa area of Spain (samples BM72, Las Llacerias section, and BM-257, Inguanzo).

\section{Archaeolithophyllum delicatum Johnson 1956 (nom. corr.)}

Fig. 13 f-i

1956 Archaeolithophyllum delicatum Johnson, OD; 53, pl. 14, figs. 4, 6 .

1980 Archaeolithoporella delicatum (Johnson); Flügel and Flügel-Kahler, p. 157, pl. 8, fig. 5.

Description: Thallus slender (300-400 $\mathrm{m} \mu$ thick), arched, branching. Rather small peri- and hypothallic cells, poorly differentiated (respectively 10-15 and 15-40 mu).

Stratigraphic distribution and range: Reported from the Late Carboniferous and Late Pennsylvanian of the Carnic Alps and American Midcontinent. Observed in Spain in the Las Llacerias Formation (sample BM-72, Khamovnikian) at Las Llacerias section, in the Demués Formation (sample BM-281, Khamovnikian) at the Demués section, and in the Puentellés Formation (sample BM-128, lower Gzhelian?) at Berodia-II section.

Remark: Vachard et al. (2001a) have suggested a continuum between Archaeolithophyllum and the Anchicodiaceae. Such transition is not substantiated by the study of our material.

\section{Genus Kasimophyllum n. gen.}

Type species: Kasimophyllum demuesensis n.gen., n.sp.

Origin of name: From the Kasimovian succession, from which the type is derived.

Diagnosis: Crustose Archaeolithophyllacea Chuvashov, 1987, composed of irregular bundles of hypothallic cells. 


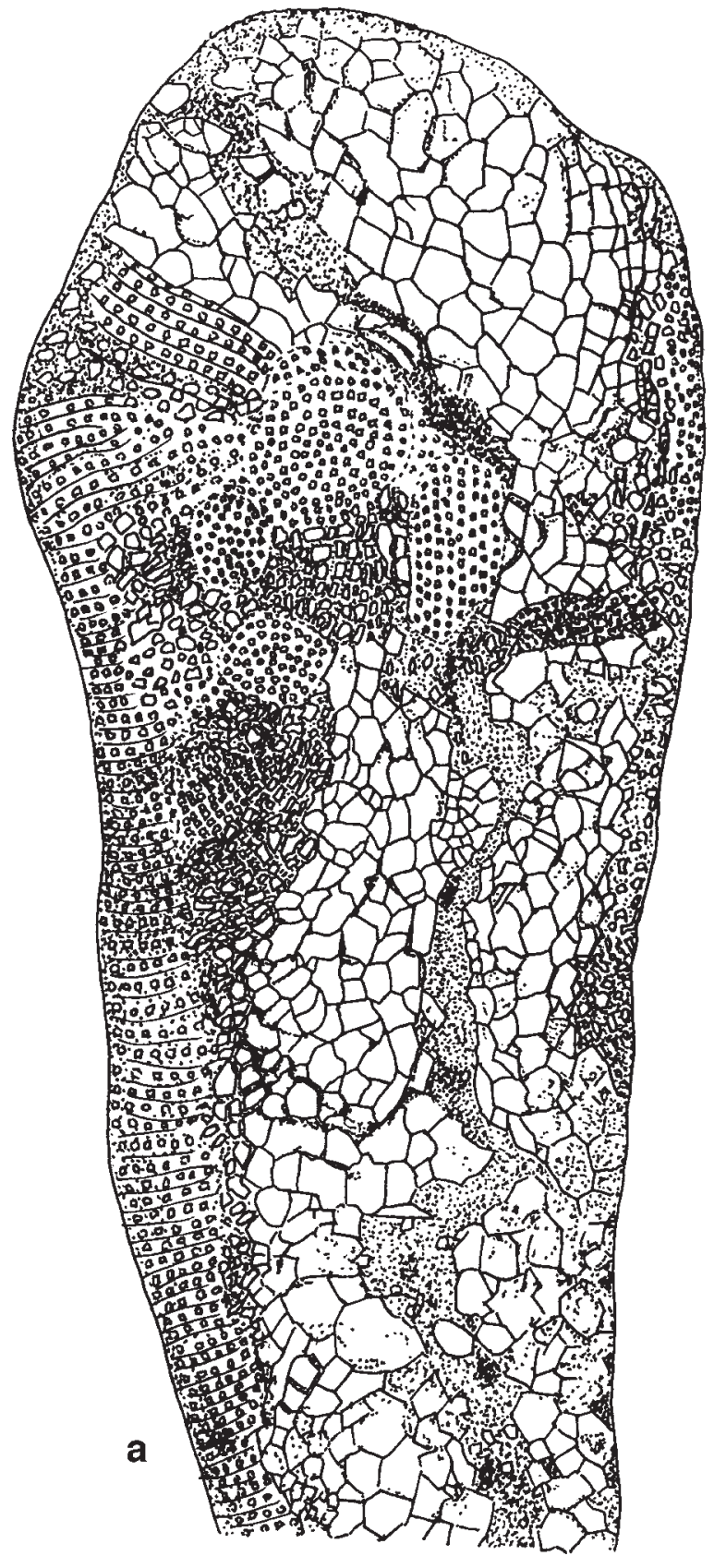

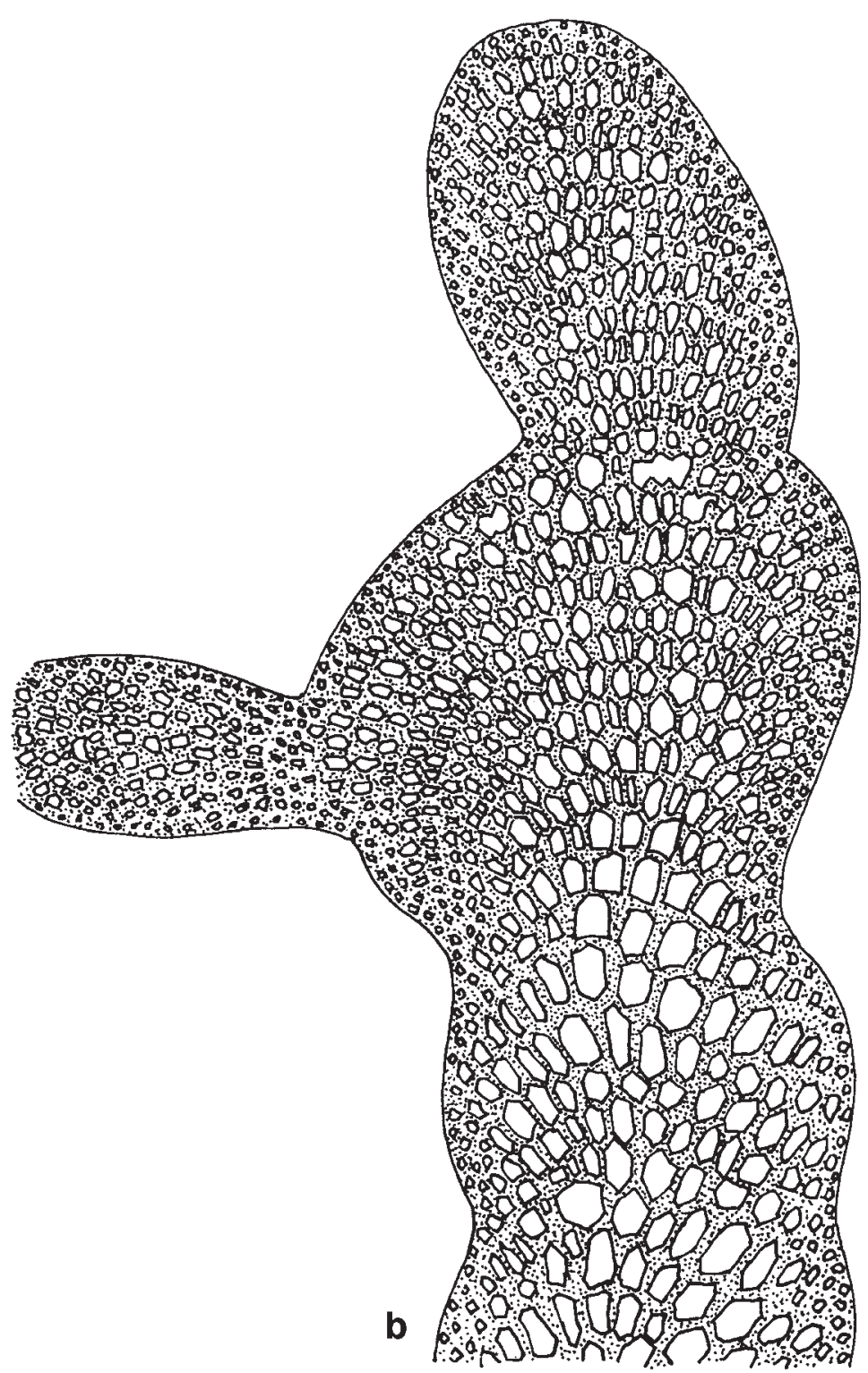

Figure 5. a, Idealized drawing of the type of Kasimophyllum demuesensis n. gen., n. sp. Order of magnitude of the thallus diameter: $1 \mathrm{~mm}$. b. Compare with an idealized section of Archaeolithophyllum. Order of magnitude of the thallus diameter: $900 \mathrm{m \mu}$.

Description: Crustose interwoven sheets or bundles of differentiated angular cells. Hypothallus composed of large, polygonal cells with no apparent growth patterns and of angular, irregular smaller cells. Perithallic cells as rows of very small, thin, subquadratic cells. Conceptacles not observed. See idealized section at figure $5 \mathrm{a}$ and compare with Archaeolithophyllum, figure $5 \mathrm{~b}$.

Comparison: Figure 5 a-b permit comparison of Kasimophyllum with its "cousin" Archaeolithophyllum. The latter has a regular coaxial hypothallus and the hexagonal cells are disposed in somewhat regular convex rows. In Kasimophyllum, the sheets of radiating bundles of cells are irregular and have no consistent growth habit. Two types of hypothallic cells are present, one very coarse angular and the other smaller and irregular. The perithallic cells are well developed and disposed in regular rows.

It is probable that Archaelithophyllum? sp., described in 1966 by Flügel from the Permian of the Carnic Alps and some Archaeolithophyllum of Minwegen, 2001, should be transferred to Kasimophyllum. 
Stratigraphic distribution and range: The material from which the holotype is derived is a marine Archaelithophyllumphylloid bafflestone with associated brachiopods, echinoderms, sponges and trilobites. There are minor amounts of bryozoans and mollusks. Foraminifers and microproblematics encountered in the level are Biseriella, Bradyina, Bradyinelloides, Climacammina, Endothyra, Endothyranella, Globivalvulina, Ozawainella, Priscella ?Pseudotaxis, Syzrania, Tetrataxis. Algae and incertae sedis are Anthracoporella, Archaelithophyllum, Eugonophyllum, Tuberitina, Tubiphytes. It has been collected from the Kasimovian (probably from Khamovnikian beds) of the Demués section (sample BM-277, upper part of the Demués Formation). Minwegen (2001) illustrated "Archaeolithophyllum" from the Kasimovian Puentellés Formation at El Pontón section (river Cares valley, Spain). Observed in Samankassou's material from the Carnic Alps (Auernig Group, Kasimovian-Gzhelian).

\section{Kasimophyllum demuesensis n. gen., n. sp.} Figs. 5 a, 13 a-b

2001 Archaeolithophyllum sp.; Minwegen, pl. 13, fig. 3; pl. 14, figs. $1,5,7$.

Origin of name: From the Demues section.

Holotype: Figure $13 \mathrm{~b}$ (enlarged and with different light orientation), figure 13 a, and idealized figure 5 a. Repository number: U. of M. 827/9-11.

Diagnosis: See the genus.

Description: Thallus crustose, more than a millimeter wide and 3 millimeters long. Interwoven bundles and sheets of subhexagonal cells $(50-120 \mathrm{m \mu})$ associated with irregular 10$40 \mathrm{~m} \mu$ cells forming the hypothallus. Perithallic cells, well developed as rows (up to $200 \mathrm{~m} \mu$ long) or grids of tiny, regular, quadratic cells $(20-30 \mathrm{m \mu})$.

Stratigraphic distribution and range: See the genus.

$$
\text { Genus Pseudokomia Rácz 1966a }
$$

\section{Pseudokomia cansecoensis Rácz 1966a}

Fig. 14 a-d

1966a Pseudokomia cansecoensis Rácz, OD; 90-91, pl. 9, figs. 5-6; pl. 10, figs. 1-3.

1987 Pseudokomia cansecoensis Rácz; Mamet et al., 51, pl. 25, fig. 5 .

2003 Komia sp.; Della Porta, fig. 3.4. J, pl. 6.2.10.

Description: Thallus grossly cylindrical, up to one millimeter in diameter, unbranched, with strong hypo/perithallic differentiation. Perithallus composed of concentric rows of small (15$20 \mathrm{mu}$ ) subquadratic cells. Hypothallic cells numerous forming filaments $15-30 \mathrm{~m} \mu$ thick.

Stratigraphic distribution and range: This uncommon alga is known from the Moscovian of the Arctic Realm (Uraloporella flora). The same age was originally reported by Rácz and observed in our material, which comes from the upper Moscovian of the Las Llacerias section (samples BM-18, BM-19, upper part of the Picos de Europa Formation, upper Myachkovian).

Genus Stacheia Brady 1876

\section{Stacheia marginuloides Brady 1876}

Fig. 14 i

For 7 taxonomic references to the taxon, see Mamet et al. (1987: 45), and add:

1983 Stacheia marginuloides Brady; Berchenko, p1. 82. fig. 5 .

1986 ?Stacheia marginuloides Brady; Skompski, 270, pl. 14, fig. 1.

1992 Stacheia marginuloides (pars) Brady; Vachard and Berkhli, pl. 4, fig. 17 (only).

1995 Stacheia marginuloides Brady; Sanchez-Chico et al., 75, pl. 6, fig. 1.

2002 Stacheia marginuloides Brady; Mamet, pl. 6, fig. 8.

Description: Thallus fusiform, with a central axis. Succession of strongly calcified arched laminae (40-60 mu in height). Lateral wall of cells quite thin $(5-10 \mathrm{~m} \mu)$. Cells quadratic to subquadratic in vertical section.

Stratigraphic distribution and range: Cosmopolitan and very common from Visean to Serpukhovian. Extends into the Moscovian in the Arctic Realm and is rarely observed at that level in NW Spain. Present material was collected from the upper part of the Picos de Europa Formation at Las Llacerias section (sample BM-13, upper Moscovian, Myachkovian).

Genus Ungdarella Kordé 1951

\section{Ungdarella uralica Maslov 1956 (non 1950)}

Fig. $14 \mathrm{j}$

For taxonomy, see 20 references in Mamet et al. (1987: 52), and add:

1979 (non) Ungdarella uralica Maslov; Bensaid et al., pl. 16, fig. 4.

1980 Ungdarella uralica Maslov; Buchroithner et al., 26, pl. 26, fig. 1.

1981 Ungdarella ex.gr. uralica Maslov; Vachard and Montenat, 65-66, pl. 11, figs. 1, 13 .

1985 Ungdarella uralica Maslov; Mamet and Pinard, pl. 3, fig. 1 .

1986a Ungdarella uralica Maslov; Nguyen, pl. 10, fig. 1.

1986b Ungdarella uralica Maslov; Nguyen, 138, pl. 15, figs. 7-8.

1988 Ungdarella uralica Maslov; Flügel and Kahler, 145, pl. 20, fig. 9.

1988 Ungdarella uralica Maslov; Fontaine and Suteethorn, pl. 77 , fig. 8.

1989 Ungdarella ex.gr. uralica Maslov; Köylüoglu and Altiner, pl. 1, fig. 10.

1990 Ungdarella uralica Maslov; Flügel, pl. 3, fig. 5. 
1990 Ungdarella uralica Maslov; Sebbar, pl. 1, fig. 3.

1990 Ungdarella uralica Maslov; Bogush et al., 124, pl. 24, figs. 1-2; pl. 25, figs. 1-5.

1991 Ungdarella uralica Maslov; Riding, pl. 3, fig. R.

1992 Ungdarella uralica Maslov; Vachard and Berkhli, pl. 1, fig. 21 ; pl. 3, figs. 13-14.

1995 (non) Ungdarella uralica Maslov; Pajic and Filipovic, pl. 50, fig. 2.

1996 Ungdarella uralica Maslov; Proust et al., pl. 1, figs. 23; pl. 2, figs. 10-11.

1996 Ungdarella uralica Maslov; Sebbar and Mamet, pl. 3, fig. 9.

1998 Ungdarella uralica Maslov; Sebbar, pl. 2, fig. 6.

2000 Ungdarella uralica Maslov; Mamet and Stemmerik, fig. 7, A-D.

2001 Ungdarella uralica Maslov; Vachard and Krainer, pl. 5, fig. 8.

2001 Ungdarella sp.; Minwegen, pl. 6, fig. 6.

2002 Ungdarella uralica Maslov; Mamet, pl. 6, fig. 2.

2003 Ungdarella uralica Maslov; Khodjanyazova and Mamet, pl. 5, figs. 6-7.

2003 Ungdarella sp.; Della Porta, fig. 4.5.A; pl. 4.1, figs. 6, 8 ; pl. 4.2, figs. $1,3,6-8$.

Description: Thallus grossly cylindrical, elongated, sometimes dichotomous. Diameter reaches one millimeter. Hypothallic single (sometimes two) row(s) of quadratic cells. They are twice the size of the surrounding cells. Multiple rows of 15-25 mu perithallic cells. Filaments at $10^{\circ}-20^{\circ}$ angle from the hypothallus. Extensive calcification makes hazardous the estimation of cell thickness.

Note: Ungdarelleae are difficult to identify (Ungdarella Kordé 1951, non Maslov 1950, Komia, Pseudokomia Rácz 1966, Cheggatella Poncet 1989, Ungdarellina Mamet 2002 and Pecharella nom.nud.) If the genera represent genuine morphological differences, they are often obscured by diagenesis. Ungdarellids are strongly calcified, hence robust carbonate stabilizers.

Stratigraphic distribution and range: A common cosmopolitan alga (Mamet, 1992) that appears in Late Viséan and is omnipresent in Bashkirian-Moscovian boundstones. It peters out in higher horizons. Observed in Spain in the upper part of the Picos de Europa Formation (sample BM-17, upper Myachkovian) at Las Llacerias section.

\section{Genus Ungdarellita $\mathrm{n}$. gen.}

Type species: Ungdarellita articulata n. gen., n. sp.

Origin of name: From the relation with Ungdarella.

Diagnosis: A segmented articulated Ungdarellaceae with regular rectangular perithallic cells.

Description: Thallus composed of a series of annular to barrel-shaped segments growing in different directions, but with an elongated pattern of growth direction (Fig. 6). Each segment composed of a central hypothallic stem and a bundle of peripheral perithallic rectangular cells with oblique insertion. See idealized reconstruction, figure 6 .

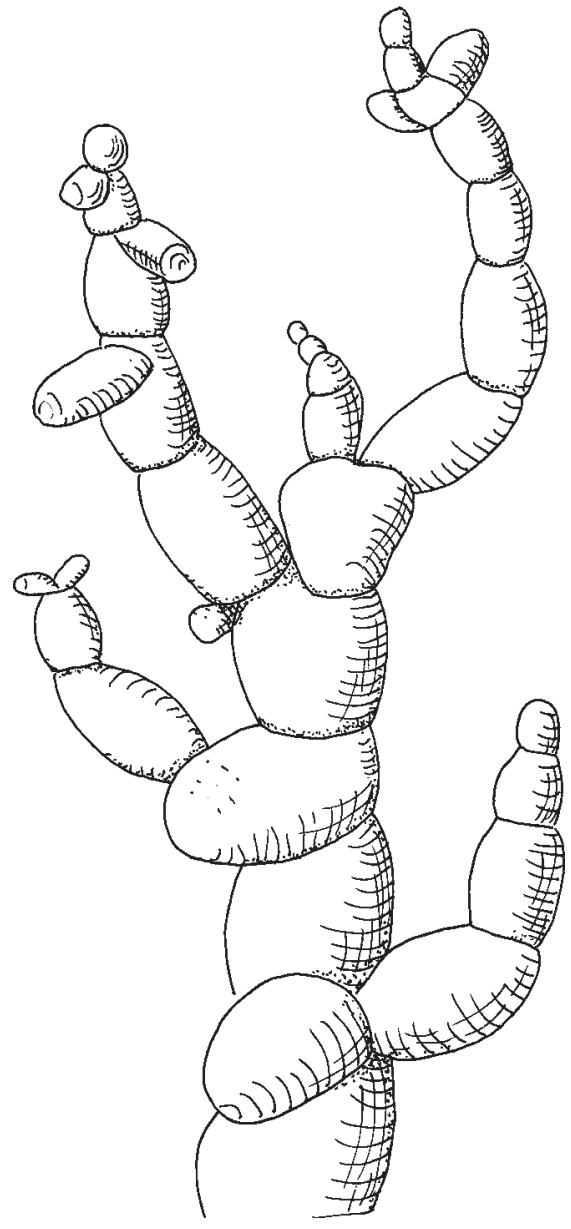

Figure 6. Idealized reconstruction of the morphology of Ungdarellita $\mathrm{n}$. gen. Lenght of thallus around $2 \mathrm{~mm}$.

Comparison: All previously described Ungdarellaceae (Ungdarella, Chegatella) have rather continuous rarely branched thalli. The new genus is articulated.

Stratigraphic distribution and range: Observed in a boundstone, Late Moscovian, Las Llacerias section. The type is derived from an Ungdarellid-beresellid-spongiostromid pellet bafflestone associated with sponges and chains of fenestellid bryozoans. It is associated with Anchicodium, Anthracoporella, Beresella, Donezella, Eugonophyllum, Komia, Stacheia, Tubiphytes and Zaporella. Foraminifers are: Apterrinellids, Bradyina, Bradyinelloides, Climacammina, Endothyra, Eolasiodiscus, Ozawainella, Pseudobradyina, Syzrania and Tetrataxis. Studied from the upper part of the Picos de Europa Formation, sample BM-16, upper Moscovian (Myachkovian), Las Llacerias section.

\section{Ungdarellita articulata n. gen., n. sp.}

Fig. 14 g-h

Origin of name: From its articulated stem.

Holotype: Figure 14 g. Repository number: U. of M. 815/17 

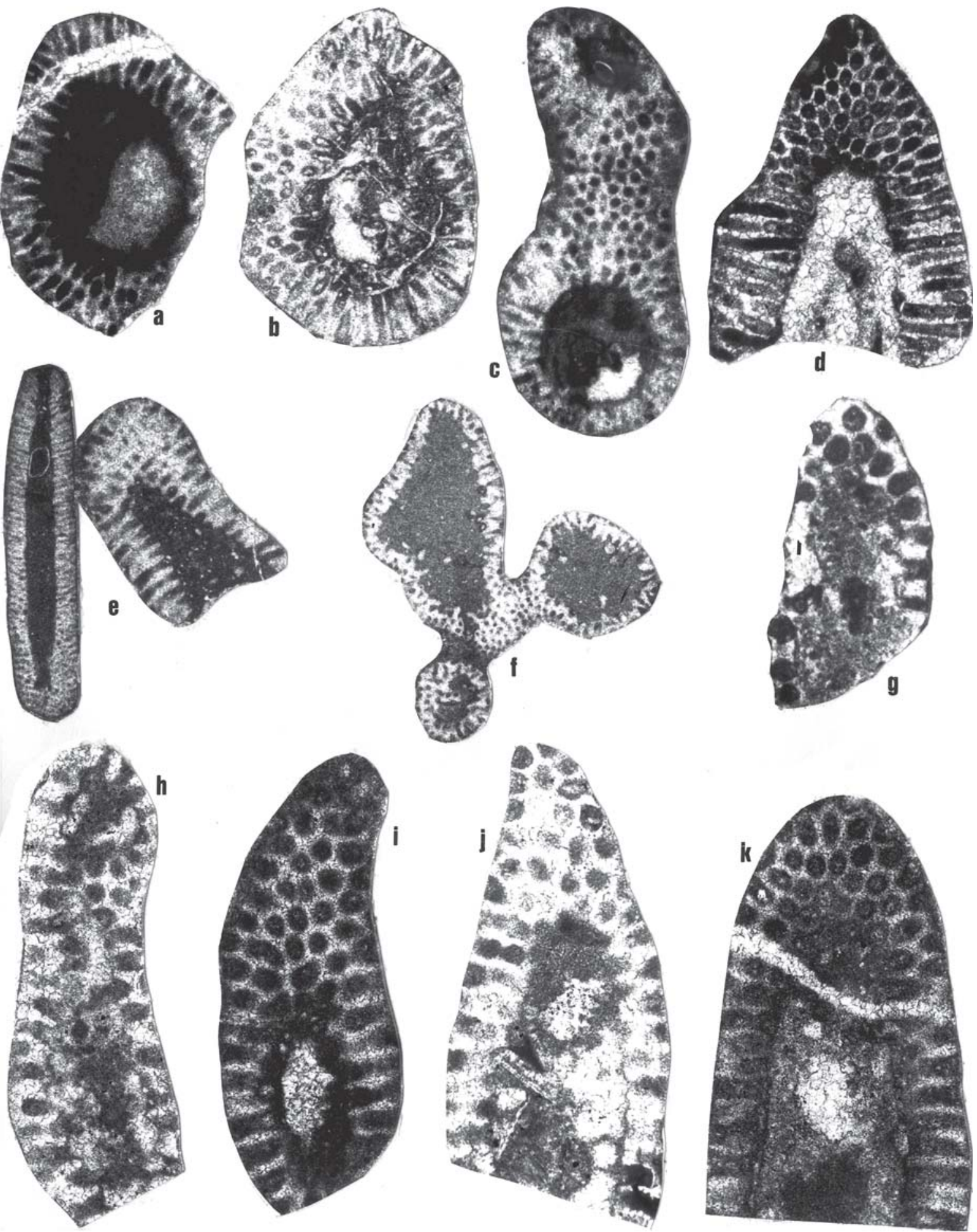

Figure 7. a-d, Anthracoporella spectabilis Pia 1920; a, U. of M. 728/8, BM-52, x30; b, U. of M. 816/0, BM-12, x30; c, U. of M. 728/25, BM-76, x30; d, U. of M. 814/24, BM-72, x41. e, Anatolipora cantabriensis n. sp., associated with Anthracoporella spectabilis Pia 1920; U. of M. 823/13, BM-11, x30, longitudinal section, holotype. f, Anthracoporella sp. U. of M. 815/ 2, BM-76, x26. g, Macroporella ginkeli Rácz 1966. U. of M. 728/16, BM-63, x30. h-k, Zaporella cantabriensis Rácz 1966; h, U. of M. 814/9, BM-72, x62; i, U. of M. 816/4, BM-11, x62; j, U. of M. 814/7, BM-72, x62; k, U. of M. 816/ 9, BM-11, x62. All from the Las Llacerias section. 
Diagnosis: See the genus.

Description: Thallus plurimillimetric ( $2 \mathrm{~mm}$ or more) composed of 20-30 (up tp 45) barrel-shaped segments. At the base they have a diameter of 200-300 $\mathrm{mm}$, for a length of $350 \mathrm{~m} \mu$. They progressively diminish in size to reach $50-100 \mathrm{~m} \mu$ (or less) and a length of 100-180 mu. Each segment composed of a central stem with coarse hypothallic threads surrounded by a small number of perithallic cells disposed at $20^{\circ}$ from the stem. There are 18-20 rows of rectangular cells in the basal segments and only half that number in the terminal segments. Rectangular cells are $20 \mathrm{~m} \mu$ wide and 40-60 mu long.

Stratigraphic distribution and range: See the genus.

\section{INCERTAE SEDIS}

Genus Berestovia Berchenko 1982 (non Berchenko 1983)

\section{Berestovia filaris Berchenko 1982 (non 1983) Fig. 14 n-o}

1982 Berestovia filaris Berchenko, OD; 53-54, pl. 12, figs. 1-4. 1983 (non) Berestovia filaris Berchenko; Berchenko, 128, pl. 84 , fig. 2 ; pl. 86 , figs. $5-6$; pl. 87 , fig. 1 .

1986 Claracrusta catenoides (Homann); Poncet, 192, pl. 3, fig. 5.

1997 Berestovia filaris Berchenko; Harris et al., pl. 9, fig. 12.

Description: Encrusting, wavy, irregular, thread-like rows of contiguous cells. Rows about 40-60 mm thick, containing interconnected cells.

Note: There is confusion in the literature as the original description of the genus by Berchenko (1982) is different from the subsequent description of 1983 that is to be referred to Vachard's Claracrusta 1981. Both genera have similar encrusting habits.

Stratigraphic distribution and range: Widespread, cosmopolitan (Eurasia-Arctic-North America. Serpukhovian to Kasimovian. It has been recorded in Spain from the Moscovian/Kasimovian transition at the Las Llacerias section (Picos de Europa Formation, sample BM-40), and from the lower Gzhelian at the Berodia-I section (upper member of the Puentellés Formation, sample BM-103).

\section{Genus Claracrusta Vachard 1981}

\section{Claracrusta catenoides (Homann 1972)}

Fig. 14 k-m, Fig. 15 o

1972 Girvanella catenoides Homann, OD; 237-241, pl. 8, fig. 59 a-c.

1980 Girvanella catenoides Homann; Flügel, pl. 9, figs. 2-5.

1981 Claracrusta catenoides (Homann); Vachard, 392-393, pl. 3, fig. 1?; pl. 7, fig. 5?; pl. 25, fig. 1?; pl. 26, figs. 1-3.

1981 Claracrusta catenoides (Homann); Vachard and Montenat, 57-58, pl. 1, fig. 1 ; pl. 8, figs. 8, 10-11; pl. 9, fig. 1 ; pl. 12, fig. 10 .

1983 Berestovia filaris Berchenko; Berchenko, 128, pl. 86, figs. 5-6; pl. 87, fig. 1 .
1984 Iberiaella carbonica Rácz, 338, fig. 3, a-f.

1986 (non) Claracrusta catenoides (Homann); Poncet, 192, pl. 3 , fig. 5 .

1990 Claracrusta catenoides (Homann); Flügel, pl. 1, fig. 4.

1990 (?) Claracrusta catenoides (Homann); Bogush et al., 84, pl. 5, fig. 10.

1991 Claracrusta sp.; Legrand-Blain and Poncet, 776, pl. 2, figs. 3-4.

1992 "Osagia" - Filaments encrusting Kansaphyllum; Baars, figs. 2-4.

1993 Claracrusta catenoides (Homann); Vachard et al., pl. 2, fig. 5.

1995 Claracrusta catenoides (Homann)(pars); Forke, pl. 17, fig. 5; (non) pl. 15, fig. 7.

1996 Claracrusta catenoides (Homann); Mamet, pl. 2, figs. 814; pl. 3, figs. 6-7.

1996 Claracrusta catenoides (Homann); Sebbar and Mamet, pl. 1, figs. 4-5.

1996 (?) Claracrusta catenoides (Homann); Vachard and Maslo, 369, pl. 1, fig. 1?.

2001 (non) Claracrusta catenoides (Homann); Vachard and Krainer, pl. 5, fig. 8 .

2001 Iberiella sp.; Minwegen pl. 5, fig. 5.

2003 Claracrusta catenoides (Homann); Khodjanyazova and Mamet, pl. 5, figs. 8-9.

Description: Encrusting, thread-like rows of irregular cells, around $60-80 \mathrm{~m} \mu$ in height. Base of rows is planar, while the top is wavy. Cells reported in the literature as tubular, but they are apparently circular-subquadratic (50-60 mu). Dimensions difficult to estimate due to calcification. Wall yellowish, Fe-rich calcite.

Stratigraphic distribution and range: Claracrusta is a very common component of the Ottonosia-Osagia oncolitic structures. Apparently world-wide. Serpukhovian? to Early Permian. In NW Spain, very abundant in association with Donezella in Bashkirian-Moscovian strata. Illustrated here from the Kasimovian of Las Llacerias section (samples BM-76, BM-77B, uppermost part of the Las Llacerias Fm, upper Khamovnikian), and the Pen section (sample BM-78, Pen Limestone, Kreviakinian).

Genus Ellesmerella Mamet, Roux and Nassichuk 1987

\section{Ellesmerella permica (Pia 1937)} Fig. $15 \mathrm{p}$

1937 Girvanella permica Pia, OD; 816, 820, pl. 9, fig. 1.

1963 Girvanella permica Pia; Johnson, pl. 78, fig. 3.

1963 Girvanella permica Pia; H. Flügel, 91-92, pl. 22, fig. 5

1966 Girvanella permica Pia; E. Flügel, 45-51, pl. 8, figs. 4-5.

1972 Girvanella permica Pia; Homann, 243-324, pl. 8, fig. 61; pl. 9, fig. 65

1981 Girvanella permica Pia; Vachard, 323, pl. 7, fig. 4.

1983 Girvanella permica Pia; Jenny-Deshusses, 160, pl. 16, fig. 1 ; pl. 24, fig. 2 .

1987 Ellesmerella permica (Pia); Mamet, Roux and Nassichuk, 15-16, pl. 3, figs. 9-11. 

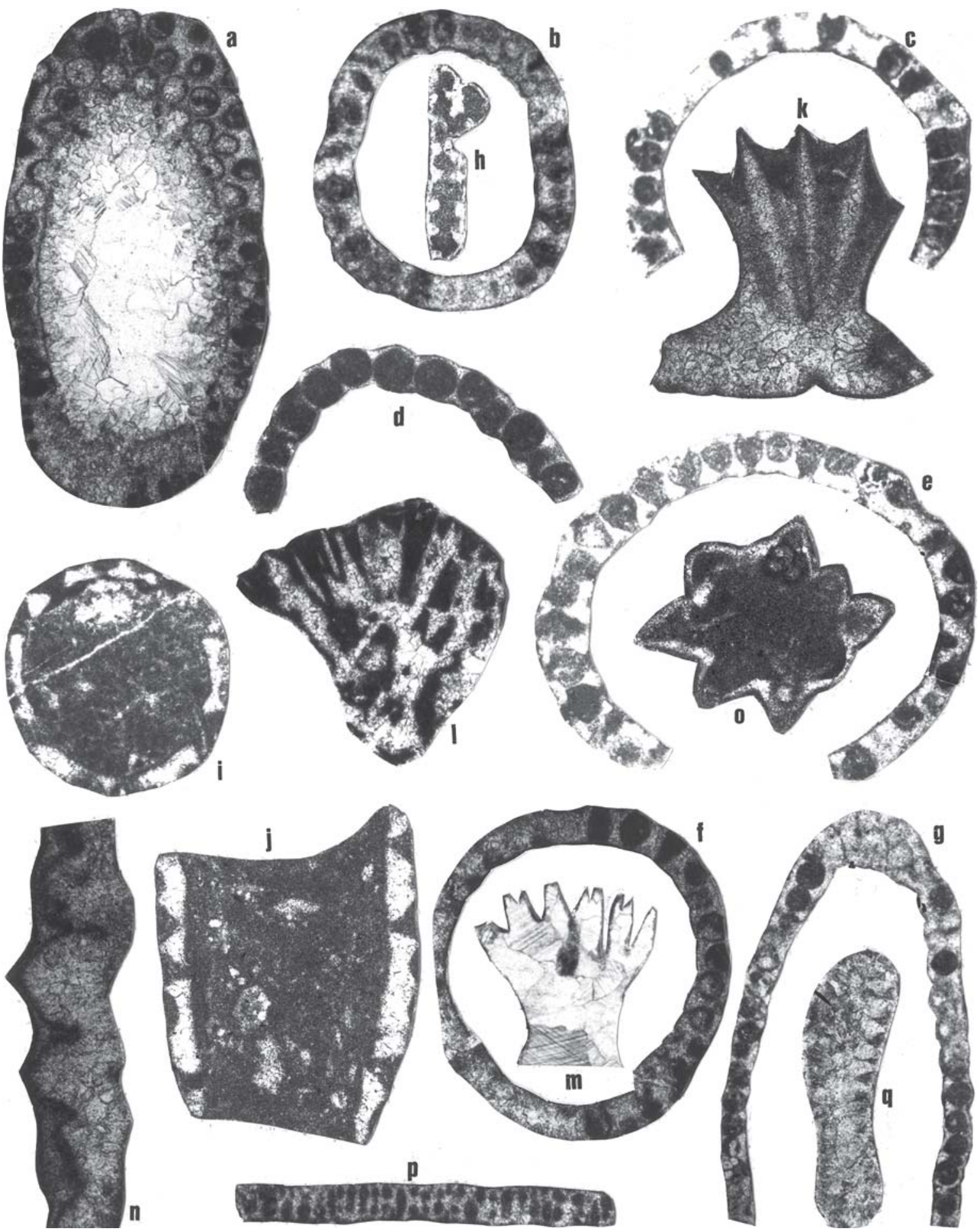

Figure 8. a-g, Gyroporella? prisca Kochansky-Devidé 1970; a, U. of M. 815/19-20, BM-46, x26. b, U. of M. 810/16, as a. c, U. of M. 810/17, as a. d, U. of M. 810/8, BM-39, x41; e, U. of M. 810/13-14, as a; f, U. of M. 815/21, as a; g, U. of M. 810/7, BM-38, x26. h, Palaeoberesella lahuseni (von Möller 1879); U. of M. 813/17, P21-39, x62. i-j, Pseudovelebitella simplex (Kochanky-Devidé 1970); i, U. of M. 833/37, BM-46, x41; j, U. of M. 816/13, BM-14, x62. k, m, Clavaporella reinae Rácz 1966; k, U. of M. 833/12, BM-28, x62; m, U. of M. 728/17, BM-72, x30. l, Dissolved Albertaporelleae; U. of M. 814/19, BM-74, x41. n, Gyroporella dissecta (Chuvashov 1974); U. of M. 833/4, BM-46, x62. o, «Pseudogyroporella» annulata Ishizima, Ozaki and Nakamura 1971; U. of M. 728/15, BM-63, x62. p, Epimastopora symetrica (Johnson 1951); U. of M. 818/17, BM-123, x30. q, Dvinella comata Khovorova 1949; U. of M. 727/13, Las Llacerias section, BM-18, x61. All from the Las Llacerias section, except P-21 (Sierra Corisa), and BM-123 (BerodiaII section). 
1995 Girvanella permica Pia; Partozoar, pl. 1, fig. 1; pl. 6, fig. 13; pl. 8, fig. 11.

2000 Ellesmerella sp.; Mamet and Stemmerik, pl. 3, B.

2001 Ellesmerella permica (Pia); Vachard and Krainer, 190, pl. 3, figs. 1-4.

2003 Ellesmerella permica (Pia); Khodjanyazova and Mamet, pl. 5, fig. 13 .

Description: Oncolitic encrustation, composed of subhorizontal files of continuous, unsegmented irregular tubes. Height of tubes variable, 10 to $40 \mathrm{~m} \mu$. Micritized wall, $10-20 \mathrm{~m} \mu$.

Stratigraphic distribution and range: Widespread in EurasiaArctic. Up to now, observed only in the Permian (see Vachard and Krainer, 2001). The Spanish material extends this range slightly lower in the Kasimovian; it has been recorded from the uppermost part of the Picos de Europa Formation at Las Llacerias section (sample BM-52, lower Kasimovian, Kreviakinian).

\section{Genus Tubiphytes Maslov 1956}

\section{Tubiphytes obscurus Maslov 1956}

Fig. 15 a, 1-m

To the 29 references reported by Homann (1972) and 26 references in Senowbari-Daryan and Flügel (1993), update the list by adding:

1989 Tubiphytes obscurus Maslov; Köylüoglu and Altiner, pl. 1 , fig. 12.

1989 Tubiphytes obscurus Maslov; Razgallah et al., pl. 1, fig. D.

1991 Tubiphytes obscurus Maslov (pars); Vachard and Ferrière, pl. 1, fig. 1, (non) 4.

1993 Tubiphytes obscurus Maslov (pars); Vachard and Clift, pl. 3, fig. 1-3, 6, (non) 4 .

1993 Shamovella obscura (Maslov); Riding, p. 72.

1993 Tubiphytes obscurus Maslov; Chuvashov et al., pl. 14, figs. 2-5.

1993 (non) Tubiphytes obscurus Maslov; Vachard et al., pl. 3, figs. 1-2.

1993 Tubiphytes obscurus Maslov; Vachard, pl. 8, fig. 17.

1995 Tubiphytes obscurus Maslov; Forke, pl. 15, fig. 9.

1995 Tubiphytes obscurus Maslov; Pajic and Filipovic, pl. 50, fig. 10.

1996 Tubiphytes obscurus Maslov; Sano and Kanmera, pl. 59, figs. 1-2; pl. 61, fig. 1-2?

1997 Tubiphytes obscurus Maslov; Vachard and Fourcade, pl. 12, fig. 1 .

1999 Tubiphytes obscurus Maslov; Weidlich and Fagerstrom, fig. 5, E-G, fig. 6, F, fig. 8, B-D.

2000 Tubiphytes obscurus Maslov; Mamet and Stemmerik, fig. 9, H-J.

2001 Tubiphytes obscurus Maslov; Vachard and Krainer, pl. 1, fig. 2.

2001b Tubiphytes obscurus Maslov; Vachard et al., pl. 3, figs. 2-3.

2001 Tubiphytes sp.; Minwegen, pl. 10, fig. 6; pl. 16, figs. 6-7.

2002 Tubiphytes sp.; Vennin et al., 2002, Fig. 5, E-H, Fig. 6, C.
2002 Tubiphytes sp.; Wahlman and Konovalova, fig. 7 A-B, fig. 8 A, fig. 9 B-E, fig. 11 A-D, fig. 12 A-D, fig. 13 A, C, E, fig. 14 E, fig. 15 C, fig. 16 A.

2003 Tubiphytes obscurus Maslov; Khodjanyazova and Mamet, pl. 5, fig. 10.

Description: Crustose, erect, cellular micritic organism, encrusting various supports (the most common being sponge spicules). When the support is segmented, growth bands are present. Microfabric composed by a reticular network of very small cells, usually obscured by micritization (hence the dark aspect, origin of the obscurus taxon).

Note: Little has been added by the numerous (137!) contributions to the original straight-forward description of Maslov (1956): "This is an encrusting (epiphyte) organism, that forms dark calcite bands around other organisms" (translated). While the genus is also reported from the Mesozoic, there are significant ultrastructure differences and the Maslov taxon is probably restricted to the Paleozoic.

Taxonomic note: It seems appropriate to attempt to bring here some ligth to the origin of Tubiphytes (=Shamovella). This microproblematicum has been the subject of numerous hypothesis that are summarized in Senowbari-Daryan and Flügel, 1993. The controversial taxon is indeed abundant in Late Paleozoic time and omnipresent in Carboniferous-Permian bioconstructions. Its ultrastructure is observed (Tubiphytes obscurus!) by intense micritization.

Tubiphytes encrusts various organisms such as foraminifers, sponges, bryozoans, phaeophytes, and has been erroneously attributed to various phyla.

An exceptionally well-preserved sample from the Permian Cache Creek is here illustrated in figure 14 a. Although derived from a very distant locality, it shed some light on our Spanish material. Associated with "normal" Tubiphytes encrustations, some of the thalli have well-preserved cellular files that strikingly resemble those of Ungdarella-Komia. Ungdarellaceae however develop strong sparitic encrustations, while Tubiphytes is highly micritized.

If our hypothesis is correct, Tubiphytes is related to encrusting red algae. This fits the known wide bathymetric distribution of this baffler-guild. Tubiphytes is abundant in the upper euphotic zone associated with bacteria, in the lower euphotic zone attached to dasycladales or to phylloids, and in the dysphotic zone with Archaeolithophyllum. It reachs the dysphotic/aphotic boundary, as could be anticipated from a rhodophyte.

Stratigraphic distribution and range: An important cosmopolitan microproblematic often associated in mounds with Archaeolithoporella and epimastoporids (Razgallah and Vachard, 1991). Abundant from the Moscovian to the Late Permian. Our Asturian illustrated material comes from the upper part of the Las Llacerias Formation at Las Llacerias section (sample BM-76B, Kasimovian, upper Khamovnikian) and the upper member of the Puentellés Formation at Berodia-II section (sample BM-122, probably lower Gzhelian). 

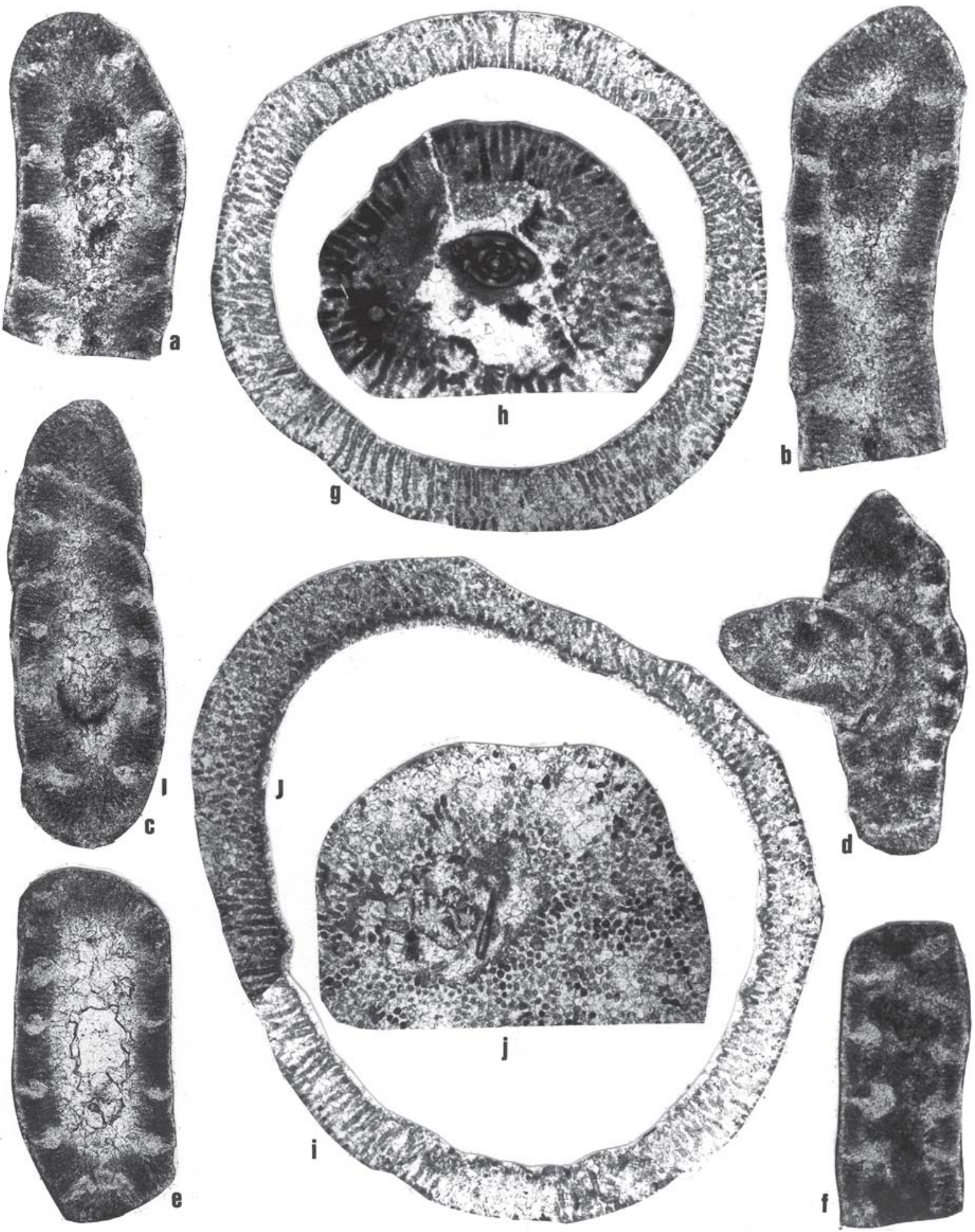

Figure 9. a-f, Beresella herminae Rácz 1966; a, U. of M. 809/12, BM-16, x78, with normal «dark bands» and «egg-shaped white bands»; b, U. of M. 809/9, as a, but x97; c, U. of M. 809/10, as a, with abnormally curved «egg-shaped white bands»; d, U. of M. 809/13, as a, with thallus dichotomy; e, U. of M. 809/1, as a, with «egg-shaped white bands»; f, U. of M. 809/7, BM-12, x97, with remnants of parietal conceptacles inside the medulla. g-j, Anthracoporella vicina Kochansky and Herak 1960; g, U. of M. 816/16-18, BM-72, x26; h, U. of M. 728/7, BM-52, x26; an axial section of Protriticites sp. is present. i, U. of M. 814/12-15, as g; j, U. of M. 814/3, as g. All from the Las Llacerias section. 


\section{Genus Penella n. gen.}

Type species: Penella pongaensis n.gen., n.sp.

Origin of name: From the hamlet of Pen.

Diagnosis: Cluster of sphaeroidal microproblematic.

Description: Sphere or coalescent cluster of spheres of various size. Wall micritic, imperforated.

Discussion: The wall of most Penella is usually dissolved and replaced by neomorphic cement. However, a few exceptionally well preserved walls show that it was originally densely micritic. In most cases, the original structure is destroyed and replaced by acicular cement or blocky sparite (compare figure $15 \mathrm{i}, \mathrm{j}, \mathrm{k}$ and same figure $\mathrm{a}-\mathrm{h}$ ).

Although sponge spicules are often observed in association with Penella, they are not responsible of swarms of spheroidal microfossils. Moreover, Penella has a characteristic wall-structure unknown among calcareous sponges.

Comparison: Penella is somewhat similar to Calcisphaera, but calcispheres do not form interconnected clusters of spheres. Penella is also somewhat similar to the incertae sedis Tuberitina (and the Tuberitinidae), but does not have attachment disks. Moreover, tuberitinids form chains, while Penella form clusters that are random. A number of similar microproblematics that form swarms are known in the Devonian and Carboniferous. For instance Bisphaera Birina 1948, Baculella Conil and Dreesen 1985 and Saccaminopsis Sollas 1921 ("Saccammina-bands", Brady, 1871). For a discussion on Baculella-Saccaminopsis see Poncet (1989) and Skompski (1993). The "Bisphaera beds" are common at the Devonian-Carboniferous transition of Russia. Similarly the Kasimovian beds of Asturias are riddled with enigmatic little spheres. They are assoociated with sponges (in situ sclerites) and algae (Anthracoporella, Anthacoporellopsis).

The type material of Penella at Pen is rich in foraminifers such as: Apterrinellidae, Hemigordius, Pseudopalaeospiroplectammina, Syzrania, Syzranella, Tetrataxis. The microflora and incertae sedis are composed of Claracrusta, Cuneiphycus, Ivanovia, Tubiphytes and Zaporella.

Penella has recently been observed in the Carnic Alps, Austria. We used the material collected by E. Samankassou (see 2002). It is abundant in fine-grained matrix bafflestone associated with Anthracoporella and sponge spicules. The genus is abundant in the KasimovianGzhelian Auernig Group and in the Gzhelian lower Pseudoschwagerina Limestone, Rattendorf Group.

Stratigraphic distribution and range: Up to now, recognized from the lower Kasimovian of the Pen section (Pen limestone, samples BM-78, BM-79, BM-85), the upper Kasimovian of the Berodia-I section (Puentellés Formation, sample BM-98), and either the upper Kasimovian or the lower Gzhelian of the Inguanzo locality (sample BM-251, Puentellés Formation).

\section{Penella pongaensis n. gen., n. sp.} Fig. 15 b-k

2001 Spiculitic wackestone with monoaxons sponge spicules. Minwegen, pl. 13, figs. 7-8.

Origin of name: From the Ponga river valley, where the locality of Pen is situated.

Holotype: Figure $15 \mathrm{j}$ (here designated). The rest of figure 15 (b-i, k) are paratypes.

Diagnosis: See the genus.

Description: Micritic sphere of group of 2, 3, up to 8 spheres that communicate with each other by means of an interruption in the wall. Average dimensions of the spheres 90-150 mu, some reaching up to $310 \mathrm{~m} \mu$. Wall micritic, 12-20 $\mathrm{m} \mu$. When dissolved, it is enlarged and reaches $30 \mathrm{~m} \mu$. No known functional aperture. No attachment disk.

Stratigraphic distribution and age: See the genus.

\section{REMARKS AND CONCLUSIONS}

This report is uncomplete as it is based on a rather limited number of sections. For instance, we have not observed in our material common algal builders that have been previously illustrated in the region (e. g. Renalcis illustrated by Della Porta, 2003, fig. 4.4.1, or Petschoria, reported by Minwegen, 2001, pl. 7, fig. 1.2). However, in spite of its limitation, it is a badly needed taxonomic update. Since the early work of Rácz, much progress has been made in suprageneric classification. But if there is much advance to be achieved, the study of Paleozoic algae remains a fascinating aspect of paleobotany.

The majority of the microflora is composed of dasycladales, observed in the form of reworked broken thalli or in growth position. Not only are they abundant and diverse, but they form intertwined bafflestones and framestones within the upper part of the euphotic zone. Donezellids and beresellids thrive in boundstones coated by Claracrusta and Berestoria but also in associated lagoons. Phylloids are fragile but can form frameworks that indicate early marine cementation and lithification (early bacterial infestation). Red algae are more resistant than their green counterparts, hence withstand higher energy in the rarefied light of deeper waters.

The flora is typically Western Paleotethyan and is similar to that of the Carnic Alps or Central Urals. The number 

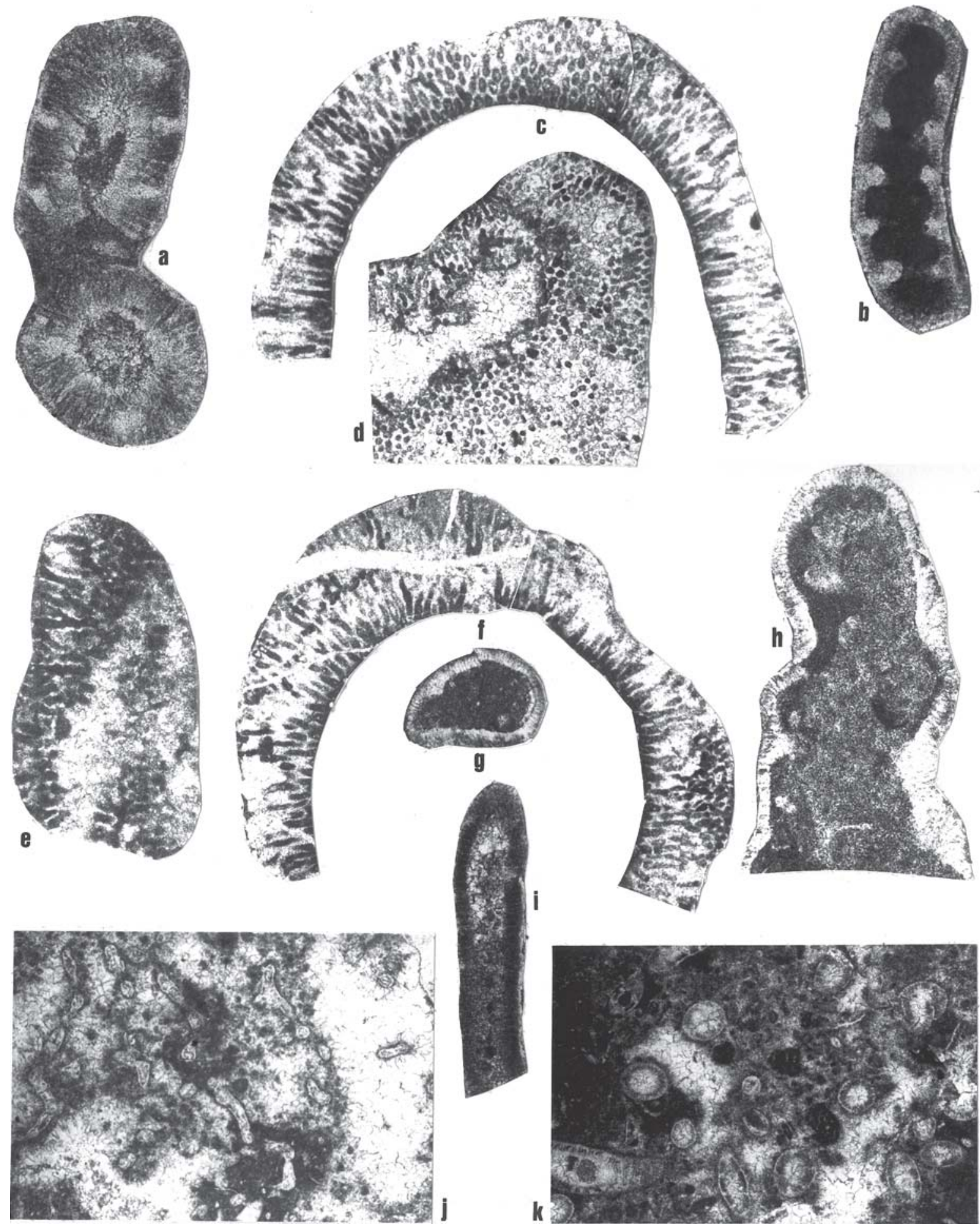

Figure 10. a-b, Beresella herminae Rácz 1966; a, U. of M. 815/16, BM-16, x62; b, U. of M. 809/6, BM-12, x97, with conceptacles simulating pseudoseptation; this Beresellae could be confused with a Palaeobereselleae. c-f, Anthracoporella vicina Kochansky and Herak 1960; c, U. of M. 816/1-2, as b, but x26; d, U. of M. 814/4, BM-72, x26, epidermic section; e, U. of M. 814/0bis, as d, showing pore dichotomies; f, U. of M. 816/5-6, as b, but x26. g-h, Anthracoporellopsis machaevii Maslov 1956; g, U. of M. 816/10, as f, but x30, transverse section; h, U. of M. 807/17, BM-25, x62, longitudinal section with poorly developed pseudo-septation and extensively developed pore dichotomy. i, Uraloporella variabilis Korde 1950. U. of M. 820/22, BM-19, x62, longitudinal section. j, Bafflestone of Donezella lutugini Maslov 1929. U. of M. 833/15, BM-28, x26. k, Bafflestone of Beresella herminae Rácz 1966. U. of M. 810/3, BM-31, x26. All from the Las Llacerias section. 
of endemic species is remarkably low. The close paleobiogeographic affinity of the Cantabrian Zone with the Carnic Alps confirms that observed for the brachiopods (Martinez Chacón and Winker-Prins, 1985) and the fusulinoideans (Villa et al., 2002).

\section{ACKNOWLEDGEMENTS}

We thank Dr. E. Samankassou (Fribourg) who kindly provided a complete suite of Carnic Alps thin-sections. They enabled close comparison with the Asturian material. We are also grateful to Dr. Elena Moreno-Eiris and Dr. E. Samankassou for their constructive reviews that greatly improved the manuscript. E. Villa acknowledge financial support from Project BTE2003-01012 of the Ministerio de Ciencia y Tecnología of Spain.

\section{REFERENCES}

Antoshkina, A. I. 1998. Organic buildups and reefs in the Paleozoic carbonate platform margin, Pechora Urals, Russia. Sedimentary Geology, 118, 187-211.

Baars, D. L. 1992. Kansaphyllum, a new Late Pennsylvanian phylloid algal genus. Journal of Paleontology, 66, 697-700.

Bahamonde, J. R., Vera, C. and Colmenero, J. R. 2000. A steep-fronted Carboniferous carbonate platform: clinoformal geometry and lithofacies (Picos de Europa, NW Spain). Sedimentology, 47, 645-664.

Barba Regidor, F. 1998. Bioconstrucciones de algas calcáreas en la sucesión Moscoviense de Columbiello (Cuenca Carbonífera central de Asturias, Zona Cantábrica). Trabajos de Geología, 20, 39-51.

Benecke, E. W. 1876. Ueber einige Versteinerungen, insbesondere aus den Umgebungen von Esino. Geognostischpaläontologische Beiträge, München, Band 2, 3, 296-317.

Bensaid, M. Termier, H., Termier, G. et Vachard, D. 1979. Le Carbonifère (Viséen Supérieur-Bachkirien) entre Bou Chber et Ich ou Mellal (Maroc central). Annales de la Société géologique du Nord, 98, 189-204.

Berchenko, O. I. 1982. New species of calcareous algae of the Upper Serpukhovian deposits of the Donbass depression (in Russian, translated). Akademiya Nauk Ukrainskoi SSR, Institut Geologicheskii Nauk (no number), 51-55.

Berchenko, O. I. 1983. Calcareous algae (in Russian, translated). In: Upper Serpukhovian substage in the Donetz Basin (Ed. V. Ia. Didkovskii). Akademiya Nauk Ukrainskoe SSR, Institut Geologicheskii Nauk (no number), 123-131.

Bogush, O. I., Ivanova, R. M. and Luchinina, V. A. 1990. Calcareous algae of the Late Famenian and Early Carboniferous from the Urals and Siberia (in Russian, translated). Akademiya Nauk SSSR, Sibirskoe Otdelenie, Trudy Instituta Geologii i Geofiziki, 745, 1-160.
Bourque, P. A., Madi, A. and Mamet, B. 1995. Waulsortiantype bioherm development and response to sea-level fluctuations: Upper Viséan of Béchar Basin. Journal of Sedimentary Research, B, 65, 80-95.

Bowman, M. B. J. 1979. The depositional environments of a limestone unit from the San Emiliano Formation (Namurian/Westphalian), Cantabrian Mountains, N. W. Spain. Sedimentary Geology, 24, 25-43.

Brady, H. B. 1876. A monograph of Carboniferous and Permian foraminifera. Palaeontographical Society Publication, 30, $166 \mathrm{pp}$.

Brazhnikova, N. E. 1956. Fauna and flora of the Carboniferous beds in the Golitzin-Volyn Basin (in Russian, translated). Akademija Nauk Ukrainskoe SSR, Institut Geologicheskii Nauk, Stratigraficheskii-paleontologicheskii Serija, 10, 16-103.

Bruner, K. R., Smosna, R. and Martínez García, E. 1998. Comparative analysis of fan-delta facies from the Carboniferous of Northwestern Spain. Revista de la Sociedad Geológica de España, 11, 181-194.

Buchroithner, M., Flügel, E. und Stattegger, K. 1980. Mikrofazies, Fossilien und Herkunft der Kalk-Gerölle in Karbon-"Flysh" der Betischen Kordilleren, Spanien. Facies, 2, 1-54.

Chanton, N. 1964. Sur la présence d'Algues calcaires dans le Carbonifère de différents bassins sahariens. Bulletin de la Société Géologique de France, 7ieme série, 6, 564-573.

Chuvashov, B. I. 1974. Permian calcareous algae of the Urals (in Russian, translated). Akademiya Nauk SSSR, Uralskii Nauchnii Centr, Trudy Instituta Geologii i Geochemii, 109, $76 \mathrm{pp}$.

Chuvashov, B. I. 1987. Red algae (Rhodophytes). Akademiya Nauk SSR, Sibirskoe Otdelenie, Trudy Institut Geologii i Geofiziki, 674, 109-140.

Chuvashov, B. I. 1988. Upper Paleozoic biostratigraphy and lithology of the Urals. Akademija Nauk SSSR, Uralskoe Otdelenie, Sbornik Nauchniz Trudov (no number), 4-19.

Chuvashov, B. I. and Anfimov, A. L. 1988. New calcareous algae from the Upper Carboniferous-Early Permian of the Urals and pre-Ural (in Russian, translated). Akademiya Nauk SSR, Sibirskoe otdelenie, Institut geologii i geofiziki "Nauka", 54-70.

Chuvashov, B. I., Shuisky, V. P. and Ivanova, R. M. 1993. Stratigraphical and facies complexes of the Paleozoic calcareous algae of the Urals. In: Studies of Fossil Benthic Algae (Ed. F. Barattolo). Bollettino della Società Paleontologica Italiana, sp. vol. 1, 93-119.

Cnudde, C. et Mamet, B. 1983. Distribution des Algues dans le Bassin de Dinant, au sommet du Tournaisien et à la base du Viséen. Bulletin de la Société belge de Géologie, 92, 185-193.

Coquel, R. and Rodríguez, R. M. 1994. Palynology of the Picos de Europa and Puentellés Formations in the Picos de Europa area (Upper Carbonifeorus, northwest Spain). Review of Palaeobotany and Palynology, 80, 65-74.

Cummings, R. H. 1955. New genera of Foraminifera from the British Lower Carboniferous. Washington Academy of Sciences, Journal, 45, 1-8. 

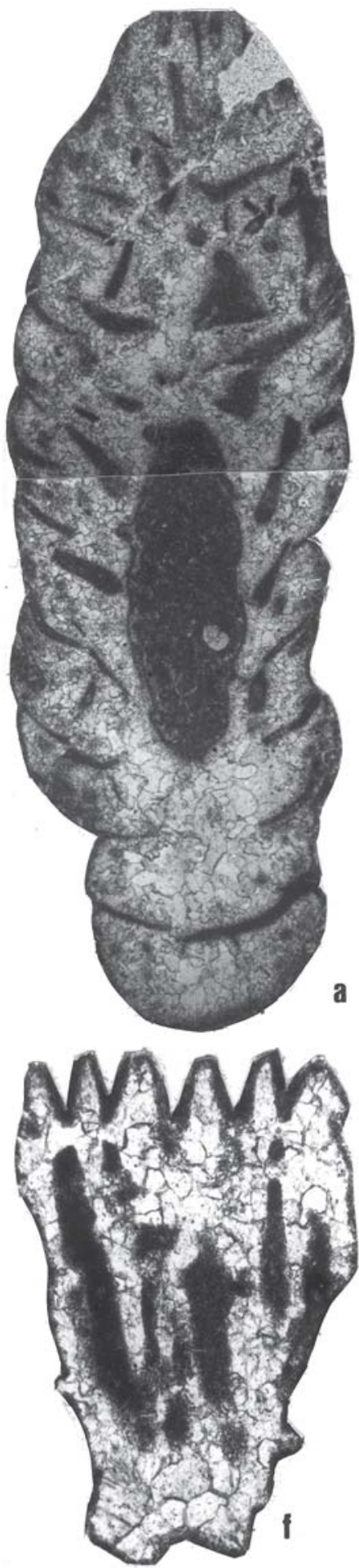

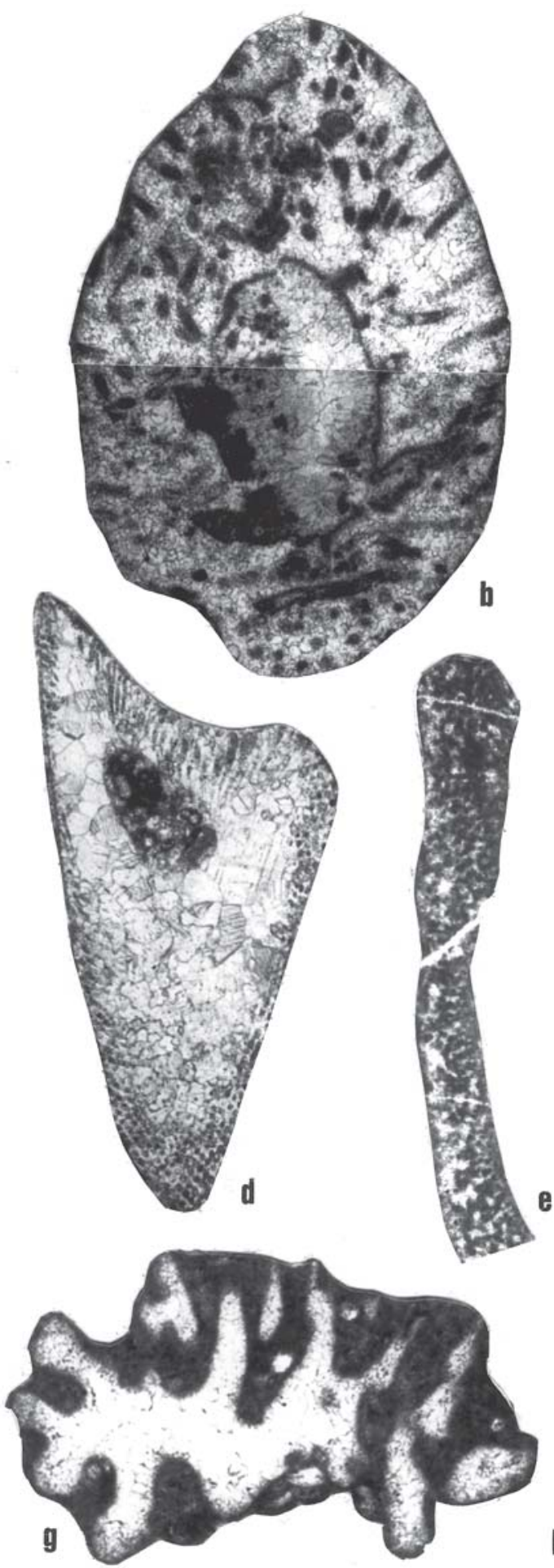

C
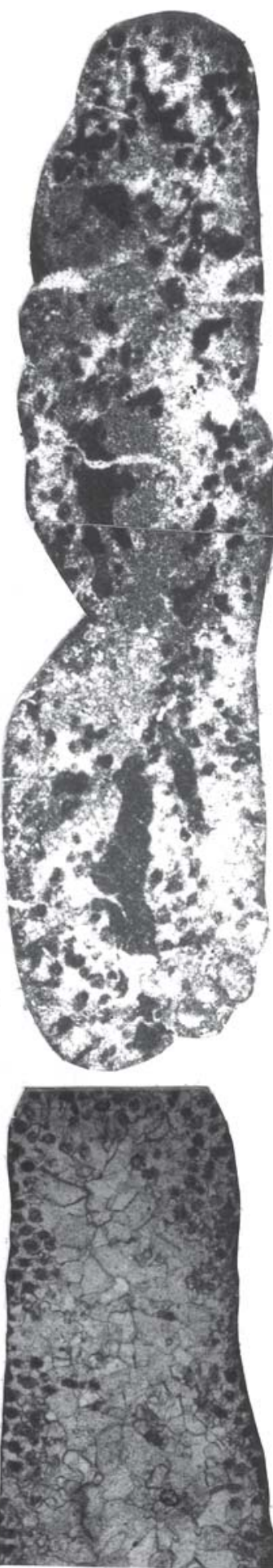

Figure 11. a-b, Herakella paradoxa Kochansky-Devidé 1970; a, U. of M. 833/13-14, BM-28, x26, longitudinal section; b, U. of M. 809/21-24, as a, oblique section. c, Hikorocodium kuramotoi Nakamura 1994. U. of M. 816/7-8, BM-12, x26, longitudinal section. d, Pelayella multiporosa n. gen., n. sp. U. of M. 728/22, BM-72, x30, oblique longitudinal section, holotype. e, Anchicodium funile Johnson 1948 sensu Torres and Baars 1992. U. of M. 833/8, as c. f, Clavaporella reinae Rácz 1966. U. of M. 814/5, BM-72, x41. g, Hikorocodium? sp. U. of M. 728/24, BM-74B, x62. h, «Vermiporella» hispanica Rácz 1966. U. of M. 818/3, BM-101, x26. All from the Las Llacerias section, except BM-101 (Berodia-I section). 
Davies, G. R. and Nassichuk, W. W. 1973. The hydrozoan Palaeoplysina from the Upper Paleozoic of Ellesmere Island, Arctic Canada. Journal of Paleontology, 47, 251-265.

De Castro, P. 2002. Remarks on Anthracoporella spectabilis Pia 1920, a supposed Permian-Carboniferous dasyclad. Bollettino della Società Paleontologica Italiana, $\mathbf{4 1}$, 3-12.

Della Porta, G. 2003. Depositional anatomy of a Carboniferous high-rising carbonate platform (Cantabrian Mountains, NW Spain). Academisch Proefschrift, Vrije Universiteit Amsterdam, 248 pp.

Della Porta, G., Kenter, J. A. M. and Bahamonde, J. R. 2002. Microfacies and paleoenvironment of Donezella accumulations across an Upper Carboniferous high-rising carbonate platform (Asturias, N. W. Spain). Facies, 46, 149-168.

Della Porta, G., Kenter, J. A. M. and Bahamonde, J. R., Immenhauser, A. and Villa, E. 2003. Microbial boundstone dominated carbonate slope (Upper Carboniferous, N Spain), microfacies, lithofacies and stratal geometry. Facies, 49, 175-208.

Deloffre, R. 1988. Nouvelle taxonomie des Algues dasycladales. Bulletin du Centre de Recherche ExplorationProduction Elf-Aquitaine, 12, 165-217.

Dingle, P. S., Bader, B., Hensen, C., Minten, B. and Schäfer, P. 1993. Sedimentology and paleoecology of Upper Carboniferous shallow-water carbonate complexes of the Cármenes Syncline (Cantabrian Mts., N. W. Spain). Zeitschrift des geologische Gesellschaft, 144, 370-395.

Dunham, R. J. 1962. Classification of carbonate rocks according to depositional texture. American Association of Petroleum Geologists Memoir, 1, 108-121.

Eichmüller, K. 1985. Die Valdeteja Formation: Aufbau und Geschichte einer oberkarbonischen Karbonatplattform (Kantabrische Gebirge, Nordspanien). Facies, 13, 45-154.

Eichmüller, K. und Seibert, P. 1984. Faziesentwicklung zwischen Tournai und Westfal D in kantabrischen Gebirge (N. W. Spanien). Deutsche Geologische Gesellschaft, Zeitschrift, 135, 163-191.

Eickhoff, H. G. 1967. Foraminiferen aus dem Unterkarbon von Frankenberg/Eder. Doktorat, Technische Hochschule Clausthall, 46 pp.

Endo, R. 1951. Stratigraphical and Paleontological Studies of the Later Paleozoic calcareous algae in Japan (I). Transactions and Proceedings of the Palaeontological Society of Japan, N. S., 4, 121-129.

Endo, R. 1959. Stratigraphical and Palaeontological Studies of the Later Paleozoic calcareous algae in Japan (XIV). The Science Reports, Saitama University, B, 3, 177-207.

Ernst, A. 2000. Permian bryozoans of the N W. Tethys. Facies, 43, 79-102.

Flügel, E. 1966. Algen aus dem Perm der Karnischen Alpen. Carinthia, II, 24, 3-76.

Flügel, E. 1977. Environmental models for Upper Paleozoic benthic calcareous algal communities. In: Fossil Algae, Recent Results and Development (Ed. E. Flügel). Springer Verlag, Berlín, 314-343.
Flügel, E. 1980. Die Mikrofazies der Kalke in TrogkofelSchichten der Karnischen Alpen. Carinthia, II, 36, 51-99.

Flügel, E. 1990. "Einschnitte" in der Entwicklung permischer Kalkalgen. Mitteilungen naturwissenschaft Verein Steiermark, Band, 120, 99-124.

Flügel, E. and Flügel-Kahler, E. 1980. Facies and biostratigraphy of the Paleozoic section near Belemedik, southern Anatolia. Facies, 18, 123-168.

Flügel, E. und Kahler, F. 1988. Algen aus den Kalken der Troghofel-Schichten der Karnischer Alpen. Carinthia II, 36, 113-182.

Flügel, H. 1963. Algen und Problematica aus dem Perm SudAnatoliens und Irans. Oesterreichische Akademie der Wissenschaften, Sitzungsberichte, Abt. 1, Bd. 172, 85-95.

Fontaine H. and Suteethorn, V. 1988. Late Palaeozoic and Mesozoic fossils of West Thailand and their environment. Committee for co-ordination of joint prospecting for mineral ressources in Asia offshore areas, CCOP, Technical Bulletin, 22, 1-217.

Fontaine H., Chonglakmani, C., Amnan, I. and Piyasin, S. 1994. A well-defined Permian biogeographic unit. Peninsular Thailand and northwest Malaysia. Journal of Southeast Asia Earth Science, 9, 129-151.

Forke, H. C. 1995. Biostratigraphie (Fusuliniden, Conodonten) und Mikrofazies im Unterperm der Karnischen Alpen (Nassfeldgebiet, Osterreich). Jahrbuch der geologischen Bundesanstalt, Wien, 38, 207-297.

Forke, H. C. and Samankassou, E. 2000. Biostratigraphical correlation of Late Carboniferous (Kasimovian) sections in the Carnic Alps (Austria/Italy): integrated palaeontological data, facies and discussion. Facies, 42, 177-210.

Ginkel, A. C. van 1965. Carboniferous fusulinids from the Cantabrian Mountains (Spain). Leidse Geologische Mededelingen, 34, 1-225.

Ginkel, A. C. van and Villa, E. 1991. Some fusulinids from the Moscovian-Kasimovian transition in the Carboniferous of the Cantabrian Mountains (NW Spain). Proceedings Koninklijke Nederlandse Akademie van Wetenschappen, 94, 299-359.

Ginkel, A. C. van and Villa, E. 1999. Late fusulinellid and early schwagerinid foraminifera: relationships and occurrences in the Las Llacerias section (Moscovian/Kasimovian), Cantabrian Mountains, Spain. Journal of Foraminiferal Research, 29, 263-290.

Granier, B. and Grgasovic, T. 2000. Les Algues Dasycladales du Permien et du Trias. Geologia Croatica, 53, 1-197.

Granier, B. and Hofmann, T. 2003. A guide to the collection of Julius Pia, $3^{\text {rd }}$ part. $8^{\text {th }}$ International Symposium on Fossil Algae, Granada, 18-20 Sept. 2003, Abstract, 24.

Groves, J. 1983. Foraminifers and Algae from the type Morrowan Region of northeastern Oklahoma and northwestern Arkansas. Oklahoma Geological Survey Bulletin, 133, 65 pp.

Groves, J. 1986. Calcareous algae and associated microfossils from Mid-Carboniferous rocks in east-central Idaho. Journal of Paleontology, 60, 476-496.

Gümbel, C. W. 1872. Die sogenannten Nulliporen (Lithotamnium und Dactylopora) und ihre Betheitligung an der 

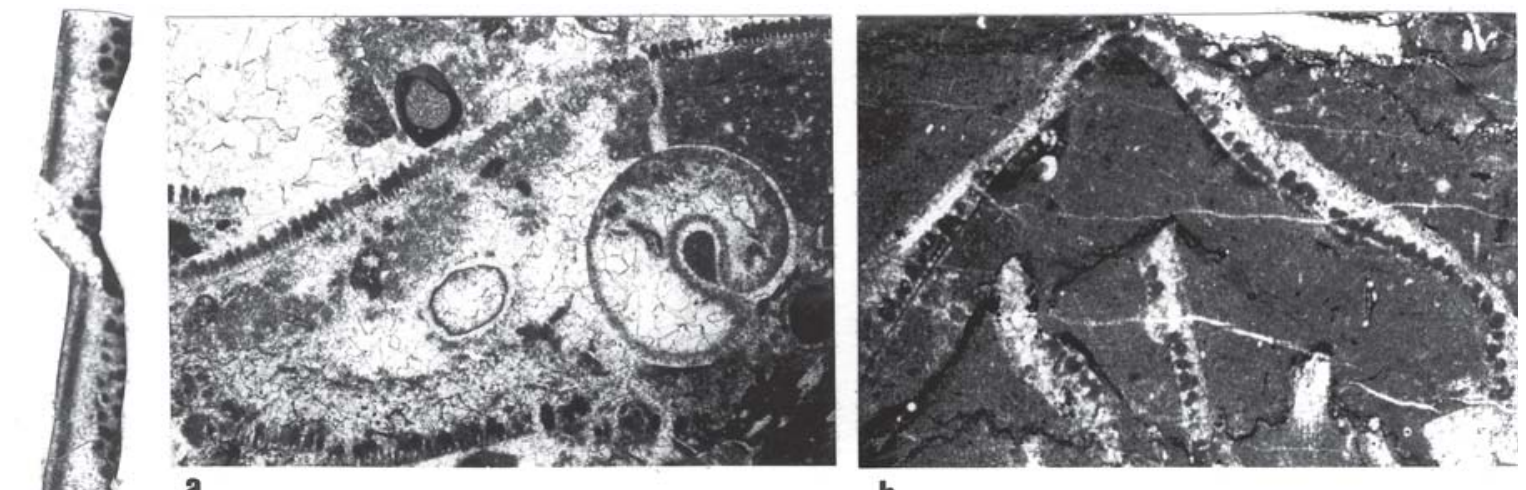

a

b
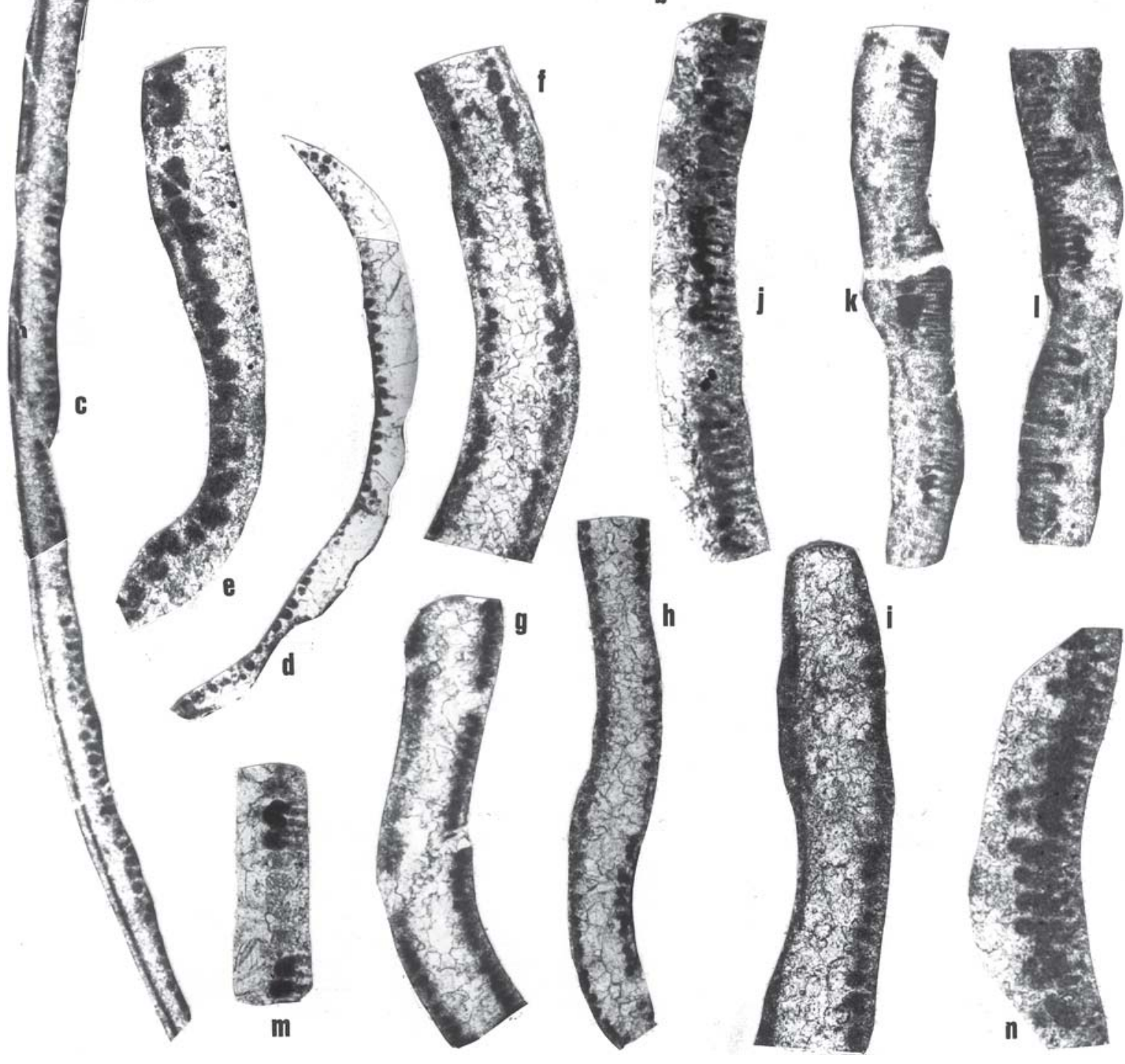

Figure 12. a, j-n, Ivanovia tenuisima Khvorova 1946; a, U. of M. 813/24, BM-72, x26. Ivanovia bafflestone with phylloid blades criss-crossing the sediment. Associated are bacterial pellets, a gastropod, Tubiphytes, Syzrania, and in situ sponge sclerites; j, U. of M. 728/21, BM-69, x62; k, U. of M. 813/23, BM-70, x30; l, U. of M. 813/22, as k; m, U. of M. 728/18, as a, but x62; n, U. of M. 728/3, BM-47, x62. b-e, Eugonophyllum mulderi Rácz 1966; b, U. of M. 827/14, BM-276, x26. Eugonophyllum mulderi bafflestone; scattered sessile foraminifers (one attached to the blade, obstructing the utricular packages), sponge sclerites, altered echinid spine; c, U. of M. 833/21-22, BM-47, x26; d, U. of M. 816/6-7, BM-105, x26; e, U. of M. 827/3, as b, but x62. f-i, Eugonophyllum johnsoni Konishi and Wray 1961; f, U. of M. 813/15, P-21, x30; g, U. of M. 833/18, BM-46, x30; h, U. of M. 813/12, as f; i, U. of M. 809/4, BM-12, x62. All from the Las Llacerias section, except BM-276 (Demués section), BM-105 (Berodia-I section), and P-21 (Sierra Corisa). 
Zusammensetzung der Kalkgesteine. Abhandlungen der II. Classe der königlige Akademie der Wissenschaften, München, band XI, 231-290.

Harris, A., Brenkle, P., Baeseman, J., Krumhardt, A. and Gruzlovic, P. 1997. Comparison of conodont and calcareous microfossil biostratigraphy and lithostratigraphy of the Lisburne Group (Carboniferous), Saddlerochit Mountains, northeast Brooks Range, Alaska. U. S. Geological Survey Professional Paper, 1574, 195-219.

Hensen, C., Dingle, P. and Schäfer, P. 1995. Primary and diagenetic mound genesis in the San Emiliano Formation of the Cármenes Syncline (Westphalian B/C, Cantabrian Mts., N. W. Spain). Facies, 32, 31-36.

Homann, W. 1972. Unter- und tief-mittelpermische Kalkalgen aus den Ratendorfer-Schichten, dem Trogkofel-Kalk und dem Tressdorfer-Kalk der Karnischen Alpen (Oesterreich). Senckenbergiana Lethaea, 53, 133-313.

Ishijima, W., Ozaki, H. and Nakamura, M. 1971. Upper Paleozoic Calcareous Algae from the Limestone at Sakaishimachibun, Saitama-ken. Bulletin of the National Science Museum, Tokyo, 14, 97-136.

Ivanova, R. M. 1973. On the Middle and Upper Viséan stratigraphy of the eastern slope of southern Urals (in Russian, translated). Akademija Nauk SSSR, Ural Nauchny Centr, Trudy Institut Geologii i Geofiziki, 82, 18-86.

Ivanova, R. M. 1988. Viséan calcareous algae of the Urals. Akademiya Nauk SSSR, Uralskoe Otdelenie, Sverdlovsk, 5-20, 13 and 51.

Ivanova, R. M. and Bogush, O. I. 1988. Famennian and Lower Carboniferous algae of Siberia. Akademiya Nauk SSSR, Sibirskoe Otdelenie, 43-64, 13.

Jansa, L. F., Mamet, B. and Roux, A. 1978. Viséan limestones from the Newfoundland Shelf. Canadian Journal of Earth Sciences, 15, 1422-1436.

Jenny-Deshusses, C. 1983. Paraglobivalvulina mira (Foraminifère): précisions morphologiques et application stratigraphique dans le Permien Supérieur d'Iran. Revue de Micropaléontologie, 25, 265-272.

Johnson, J. H. 1946. Lime-secreting algae from the Pennsylvanian and Permian of Kansas. Bulletin of the Geological Society of America, 57, 1087-1120.

Johnson, J. H. 1951. Permian calcareous algae from the Apache Mountains, Texas. Journal of Paleontology, 25, 21-30.

Johnson, J. H. 1956. Archaeolithophyllum, a new genus of Paleozoic coralline algae. Journal of Paleontology, 30, 53-55.

Johnson, J. H. 1960. Paleozoic Solenoporaceae and related red algae. Quarterly Colorado School of Mines, 55 (3), 77 pp.

Johnson, J. H. 1963. Pennsylvanian and Permian algae. Quarterly Journal of the Colorado School of Mines, 58 (3), 1-211.

Julivert, M. 1971. Décollement tectonics in the Hercynian Cordillera of northwest Spain. American Journal of Science, 270, 1-29.

Khodjanyazova, R. and Mamet, B. 2003. Paleozoic calcareous algae from southern Tian Shan, Uzbekistan, Central Asia. Geologica Belgica, 6, 97-117.
Khvorova, L. V. 1946. On a new algal genus from the Middle Carboniferous deposits of the Moscow Basin (in Russian, translated). Doklady Akademija Nauk SSSR, 53, 737-739.

Khvorova, L. V. 1949. New genus of verticillated Siphoneae from the Carboniferous of the Moscow Syncline. Doklady Akademiya Nauk SSSR, 65, 749-752.

Kiessling, W., Flügel, E. and Golonka, J. 1999. Paleoreef maps: Evaluation of a comprehensive database on Phanerozoic reefs. American Association of Petroleum Geologists, Bulletin, 83, 1552-1587.

Kochansky-Devidé, V. 1964a. Die Fusuliniden und Kalkalgen des jugoslavischen Karbons. Compte-rendu, $5^{\text {ième }}$ Congrès pour l'avancement de la Stratigraphie du Carbonifère, 513-518.

Kochansky-Devidé, V. 1964b. Velebitella, eine neue jungpaläozoische Diploporeengattung und ihre phylogenetischen Verhaltnisse. Geoloski Vjesnik Instituta za geoloska istrazivanja u Zagrebu, 17, 135-142.

Kochansky-Devidé, V. 1970. Die Kalkalgen des Karbons vom Velebit-Gebirge (Moskovien und Kasimovien). $\mathrm{Pa}$ laeontologia Jugoslavica, 10, 1-32.

Kochansky-Devidé, V. and Herak, M. 1960. On the Carboniferous and Permian Dasycladaceae of Yugoslavia. Geoloski Vjesnik, 13, 65-95.

Kochansky-Devidé, V. und Ramovs̆, A. 1966. Oberkarbonische Mikrofossilien und stratigraphische Entwicklung in den Westkarawanken. Razprave, Slovensko Akademie Znan, Umetn, 9, 199-233.

Konishi, K. 1956. Anatolipora, a new dasycladaean genus and its algal associates from the Lower Carboniferous of Japan. Quarterly Journal, Colorado School of Mines, 51, 111-127.

Konishi, K. and Wray, J. L. 1961. Eugonophyllum, a new Pennsylvanian and Permian algal genus. Journal of Paleontology, 35, 659-666.

Kordé, K. B. 1950. On the morphology of the Carboniferous verticillated Siphonae of septentrional Urals (in Russian, translated). Doklady Akademija Nauk SSSR, 73, 569-571.

Kordé, K. B. 1951. New calcareous algal genera from the Carboniferous deposits of northern Urals (in Russian, translated). Bulletin Moskovskogo obshestva ispitatelei prirody, Trudy otdel geologii, 1, 175-182.

Köylüoglu,M. et Altiner, D. 1989. Micropaléontologie et biostratigraphie du Permien Supérieur de la région d'Hakkari (S. E. Turquie). Revue de Paléobiologie, 8, 467-503.

Kroeger, K. F., Reuter, M. and Brachert, T. C. 2003. Temperature and water depth indices based on coralline red algae. $8^{\text {th }}$ International Symposium on Fossil Algae, Granada, 18-20 Sept. 2003, Abstract, 33-34.

Kulik, E. L. 1964. Beresellids from the Carboniferous of the Russian Platform (in Russian, translated). Paleontologicheskii Zhurnal, 2, 99-114.

Kulik, E. L. 1978. Calcareous green algae of the Asselian and Sakmarian stages of the Shaktau bioherm massif (Bashkiria) (in Russian, translated). Voprosy Mikropaleontologii, 21, 182-215.

Legrand-Blain, M. et Poncet, J. 1991. Encroûtements et perforations de tests de Brachiopodes dans le Carbonifère du 

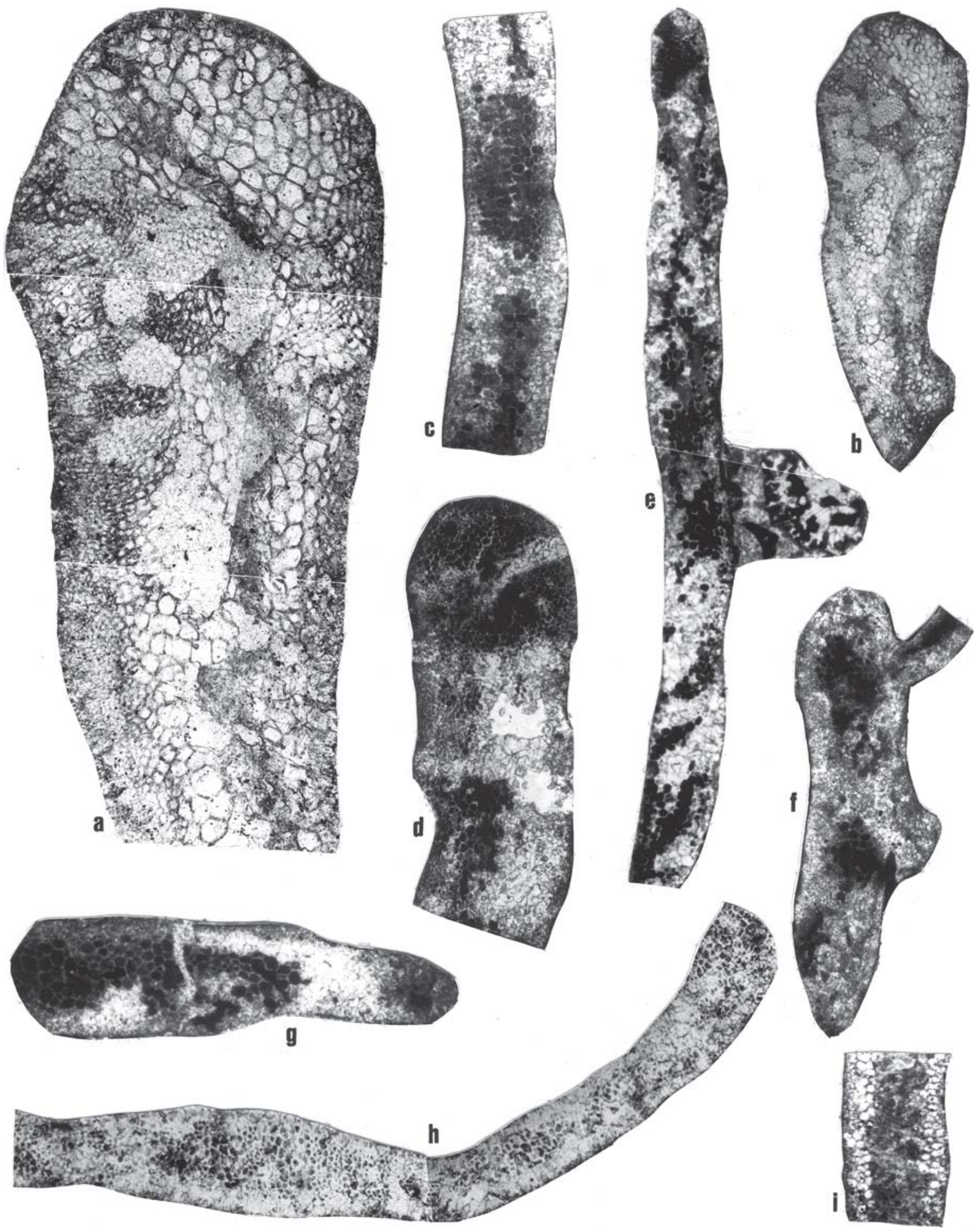

Figure 13. a-b, Kasimophyllum demuesensis n. gen., n. sp.; a, U. of M. 827/9-11, BM-277, Demués section, x62, longitudinal section, enlargment of part of the holotype, with different nicol orientation; b, Same as a, x 26, holotype. c-e, Archaeolithophyllum johnsoni Rácz 1966; c, U. of M. 825/3, BM-257, Inguanzo, x26, longitudinal section; d, U. of M. 725/19-20, BM-72, Las Llacerias section, x26, longitudinal section with a fragment of Hikorocodium?; e, U. of M. 815/ 23, BM-11, Las Llacerias section, x26. f-i, Archaeolithophyllum delicatum Johnson 1956; f, U. of M. 814/6, as d, but x30, longitudinal section; g, U. of M. 825/14, as c, but x30, showing branches; h, U. of M. 818/20-21, BM-128, BerodiaII section, x26, longitudinal section; i, U. of M. 827/18, BM-281, Demués section, x26, with the perithallic cells. 
Sahara algérien. Bulletin de la Société géologique de France, 8ième sér., 7, 775-789.

Loeblich A. R. and Tappan, H. 1964. Protista: Part C. In: Treatise on Invertebrate Paleontology (Ed. R. C. Moore). Geological Society of America and University of Kansas Press, 900 pp.

Lotze, F. 1945. Zur Gliederung der Varisziden der Iberisechen Meseta. Geotektonic Forschungen, 6, 78-92.

Madi, A., Bourque, P. A. and Mamet, B. 1996. Depth-related ecological zonation of a Carboniferous carbonate ramp: Upper Viséan of Béchar Basin, western Algeria. Facies, 35, 59-80.

Makhaev, V. N. 1937. Algae as index fossils (in Russian, translated). Doklady Akademija Nauk SSSR, 15, 475-478.

Malakhova, N. P. 1975. Foraminifers, algae and stratigraphy of the Lower Viséan of the eastern slope of the southern Urals. Akademija Nauk SSSR, Uralskii Filial, Trudy Institut Geologii i Geochemii, 112, 71-100.

Mamet, B. 1976. An atlas of microfacies in Carboniferous carbonates of the Canadian Cordillera. Geological Survey of Canada Bulletin, 255, 1-131.

Mamet, B. 1991. Carboniferous calcareous algae. In: Calcareous Algae and Stromatolites (Ed. R. Riding). SpringerVerlag, Berlín, 370-451.

Mamet, B. 1992. Paléogeographie des algues calcaires marines carbonifères. Revue Canadienne des Sciences de la Terre, 29, 174-194.

Mamet, B. 1996. Algues calcaires marines du Paléozoique Supérieur (Equateur, Bolivie). Annales de la Société géologique de Belgique, 117, 155-167.

Mamet, B. 2002. Carboniferous marine algae, lower part of the Akiyoshi Limestone Group (Japan). Canadian Society of Petroleum Geologists, Memoir, 19, 492-528.

Mamet, B. and Martínez, C. 1981. Late Viséan microfossils of the Las Caleras Bajas limestones (Córdoba, Spain). Revista Española de Micropaleontología, 13, 105-118.

Mamet, B. and Pinard, S. 1985. Carboniferous algae from the Peratrovich Formation, southeastern Alaska. In: Paleoalgology: Contemporary Research and Applications (Eds. D. Toomey and M. H. Nitecki). Springer-Verlag, Berlin, Heidelberg New York, 91-100.

Mamet, B. et Préat, A. 1992. Algues de Dévonien Moyen de Wellin (Synclinorium de Dinant, Belgique). Revue de Micropaléontologie, 35, 53-75.

Mamet, B. et Roux, A. 1974. Sur quelques Algues Tubulaires Scalariformes de la Téthys paléozoique. Revue de Micropaléontologie, 17, 134-156.

Mamet, B. et Roux, A. 1975. Dasycladacées dévoniennes et carbonifères de la Téthys occidentale. Revista Española de Micropaleontologia, 7, 245-295.

Mamet, B. et Roux, A. 1977. Algues rouges dévoniennes et Carboniféres de la Téthys occidentale. Revue de Micropaléontologie, 19, 215-266.

Mamet, B. et Roux, A. 1978. Algues viséennes et namuriennes du Tennessee (Etats-Unis). Revue de Micropaléontologie, 21, 68-97.

Mamet, B. et Rudloff, B. 1972. Algues carboniféres de la partie septentrionale de l'Amérique du Nord. Revue de Micropaléontologie, 15, 75-114.
Mamet, B. and Villa, E. 1995. A revision of the Dasycladale alga Uraloporella (Chlorophycophyte, Upper Paleozoic, Asturias, Spain). Revista Española de Paleontología, Homenaje al Dr. Guillermo Colom, 48-54.

Mamet, B. and Stemmerik, L. 2000. Carboniferous algal microflora, Kap Jungersen and Foldedal Formations, Holm Land and Amdrup Land, eastern North Greenland. Geology of Greenland Survey, Bulletin, 187, 79-101.

Mamet, B., Mortelmans, G. et Roux, A. 1979a. Algues viséennes du sondage de Turnhout (Campine, Belgique). Annales de la Société géologique de Belgique, 101, 351-383.

Mamet, B., Bamber, E. W. and Macqueen, R. W. 1986. Microfacies of the Lower Carboniferous Banff Formation and Rundle Group, Monkman Pass map area, British Columbia. Geological Survey of Canada Bulletin, 353, $1-93$.

Mamet, B., Roux, A. et Nassichuk, W. 1987. Algues carbonifères et permiennes de l'Arctique canadien. Geological Survey of Canada Bulletin, 342, 1-143.

Mamet, B., Préat, A. et Lehmami, M. 1999. Algues calcaires marines du Dévonien marocain (Meseta). Revue de Micropaléontologie, 42, 301-314.

Marquínez, J., Méndez, C. A., Menéndez-Álvarez, J. R., Sánchez de Posada, L. C. y Villa, E. 1982. Datos bioestratigráficos de la sucesión carbonífera (Turnesiense-Kasimoviense) de Las Llacerías, Picos de Europa, Norte de España. Trabajos de Geología, 12, 187-193.

Martínez-Chacón, M. L. and Winkler-Prins, C. F. 1985. Upper Carboniferous (Kasimovain) brachiopods from Asturias (N Spain). Compte Rendu X Congrès International de Stratigraphie et de Géologie du Carbonifère, 2, 435-448.

Martínez García, E. y Villa, E. 1998. El desarrollo estratigráfico en las unidades alóctonas del área de GamonedoCabrales (Picos de Europa, Asturias, NW de España). Geogaceta, 24, 215-218.

Martínez García, E. y Villa, E. 1999. Edad de los primeros signos de actividad tectónica en el Carbonífero Superior de los Picos de Europa (Asturias, NO de España). Trabajos de Geología, 21, 229-237.

Martínez García, E., Rodríguez-Arango, R. and Villa, E. 1985. The unconformable marine Kasimovian strata of the Sellaño Basin. In: Carboniferous of the Iberian Peninsula (Ed. M. J. Lemos de Sousa). Annales Faculdade de Ciencias Porto, Suppl., 64, 35-40.

Maslov, V. P. 1929. Microscopic algae from the Carboniferous limestones of the Donetz Basin (in Russian, translated). Bulletin du Comité géologique, 48, 115-138.

Maslov, V. P. 1950. Significance of red algae for the Stratigraphy of the USSR (in Russian, translated). Doklady Akademija Nauk SSSR, 70, 75-78.

Maslov, V. P. 1956, Fossil calcareous algae of the USSR (in Russian, translated). Trudy Geologicheskogo Instituta, 160, 1-301.

Maslov, V. P. and Kulik, E. L. 1956. A new algal tribe (Bereselleae) in the Carboniferous of the USSR (in Russian, translated). Doklady Akademija Nauk SSSR, 106, 126-129. 


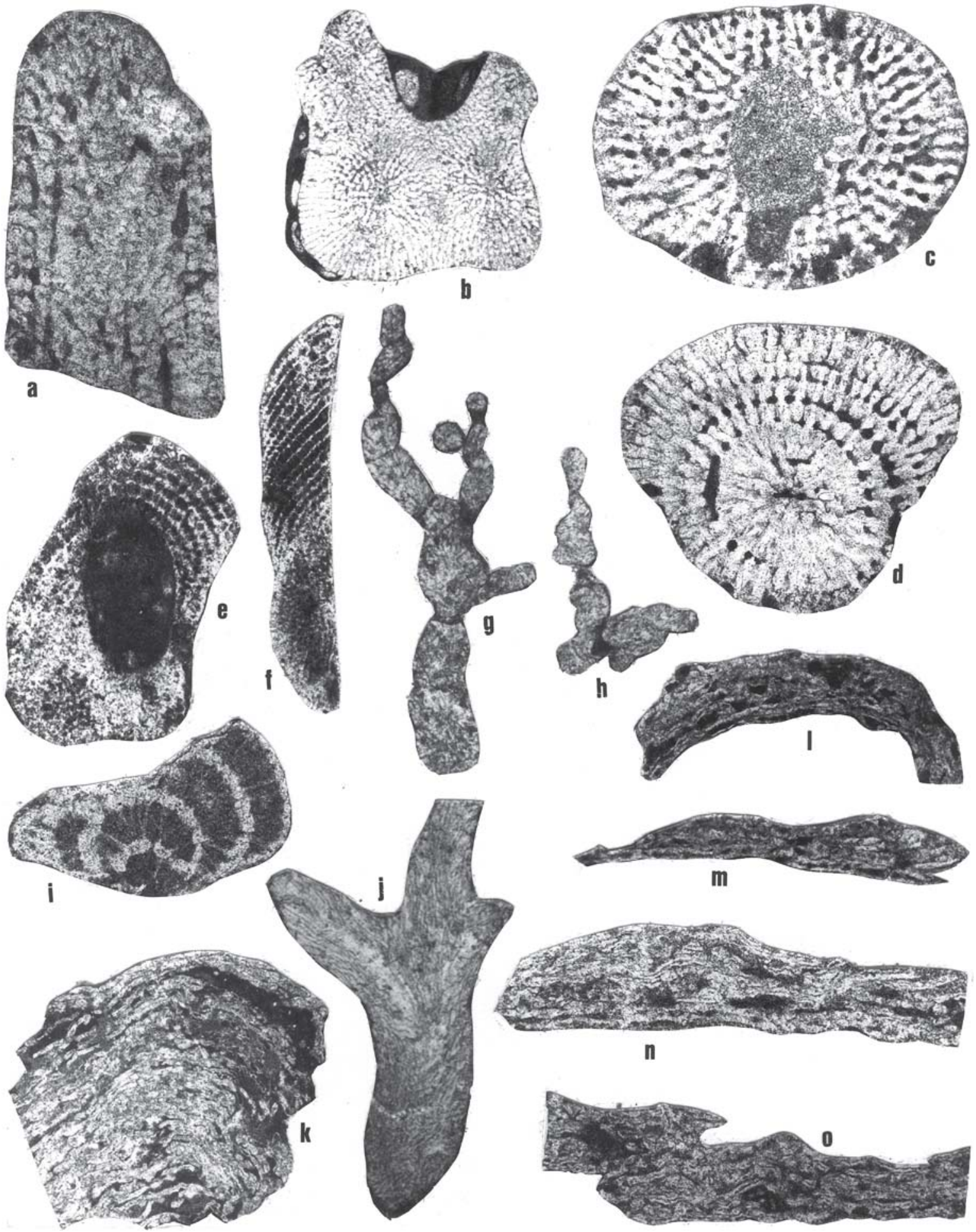

Figure 14. a-d, Pseudokomia cansecoensis Rácz 1966; a, U. of M. 820/17, BM-18, x62; b, U. of M. 822/18, BM-19, x26, encrusted by Tubiphytes obscurus Maslov 1956; c, U. of M. 822/10, as b, but x62, transverse section; d, U. of M. 822/9, as c, oblique transverse section. e, Fourstonella fusiformis (Brady 1876), U. of M. 814/10, BM-72, x62, oblique longitudinal section. f, «Fourstonella»(?) johnsoni (Flügel 1966) (=Efluegelia), U. of M. 728/29, BM-77B, x62, longitudinal section. g-h, Ungdarellita articulata n. gen., n. sp.; g, U. of M. 815/17, BM-16, x41, longitudinal section along growth axis, holotype; h, U. of M. 809/15, as g, but x30, oblique section, paratype; i, Stacheia marginuloides Brady 1876. U. of M. 809/8, BM-13, x97, longitudinal section; j, Ungdarella uralica Maslov 1956, U. of M. 819/10, BM-17, x30, longitudinal section. k-m, Claracrusta catenoides (Homann 1972); k, U. of M. 815/10, BM-78, x26; l, U. of M. 728/28, BM77B, x62; m, U. of M. 728/26, BM-76, x62. n-o, Berestovia filaris (Berchenko 1982); n, U. of M. 810/10, BM-40, x62; o, U. of M. 818/4, BM-103, x62. All from the Las Llacerias section, except BM-78 (Pen section), and BM-103 (BerodiaI section). 
Massa, D. et Vachard, D. 1979. Le Carbonifére de la Libye Occidentale. Revue Institut Francais du Pétrole, 34, 3-64.

Méndez, C. A. 2002. Upper Carboniferous conodonts (upper Moscovian-middle Kasimovian) from the Las Llacerias section (Cantabrian Mountains, North Spain). Abstracts, ECOS-VI (European Conodont Symposium VII), Toulouse, France, 44.

Merino-Tomé, O., Colmenero, J. R., Bahamonde, J. R. y Fernández, L. P. 2001. Estratigrafía y sedimentología de la sucesión estefaniense del sector nororiental de la región de Picos de Europa (Zona Cantábrica). Studia Geologica Salmanticensia, 37, 25-90.

Milanovic, M. 1982. Carboniferous microfossil associations from Gorski Kotar, Hrvatsko Zagorje and Banija. $\mathrm{Pa}$ laeontologia jugoslavica, 28, 1-34.

Minwegen, E. 2001. Die Biokonstruktionen im Pennsylvanium des Kantabrischen Gebirges (Nordspanien). Kölner Forum für Geologie und Paläontologie, 9, 1-139.

Möller, V. von 1879. Die Foraminiferen der russischen Kohlenkalk. Académie des Sciences Impériale de St. Pétersbourg, sér. 7, 27, 5, 1-131.

$\mathrm{Mu}$, Xinan 1982. Some calcareous algae from Xizang (in Chinese, with an English abstract). In: Series of the scientific expedition to the Qinghai-Xizang Plateau. Science Press, Beijing, 205-240.

$\mathrm{Mu}$, Xinan 1985. Late Carboniferous algae (in Chinese). In: Geology and Paleontology in Mt. Tomur, Tianshan. Xinjiang People's Publishing House, 142-146.

Mu, Xinan, Piller, W. E., Hubmann, B. and Weihua, L. 2003. A study of Anthracoporella from the Upper Carboniferous of the Carnic Alps (Austria). $8^{\text {th }}$ International Symposium on Fossil Algae, Granada, 18-20 Sept. 2003, Abstract, 76-77.

Muromtseva, A. A. 1979. Six species of calcareous algae from the Carboniferous of the Lvov-Volhyn Basin. Paleontologicheskii Sbornik Lvovskii Gosudarstvenii Universitet, 16, 89-94.

Nakamura, M. 1994. Algal remains from the Akiyoshi Limestone Group. Bulletin, Akiyoshi-Dai Museum of Natural History, 29, 1-45.

Nguyen, D. T. 1986a. Foraminifers and algae from the Permian of Kampuchea. Committee for co-ordination of joint prospecting for mineral ressources in Asia offshore areas, CCOP, Technical Bulletin, 18, 116-137.

Nguyen, D. T. 1986b. Foraminifers and algae from the Permian at Guguk Bulat, Sumatra. Committee for coordination of joint prospecting for mineral ressources in Asia offshore areas, CCOP, Technical Bulletin, 18, 138-147.

Pajic, V. and Filipovic, I. 1995. Foraminiferi i Alge. In: Carboniferous of northwestern Serbia (Ed. I. Filipovic). Mémoire Service Géologique "Gemini”, 25, 50-59.

Papenfuss, G. F. 1946. Notes on algal nomenclature. Taxon, 7, 104-109.

Partoazar, M. 1995. Permian deposits in Iran. Geological Survey Iran, 22, 1-7.

Pelhate, A. 1968. Algues et Foraminifères viséens du Bassin de Laval(Massif armoricain). Bulletin de la Société Géologique de France, 7ième série, 9, 897-902.

Pelhate, A. 1969. Micropaléontologie des calcaires dinantiens du Bassin de Laval. Bulletin de la Société Géologique et Minéralogique de Bretagne, 27-76.

Pérez-Estaún, A., Bastida, F., Alonso, J. L., Marquínez, J., Aller, J., Álvarez-Marrón, J., Marcos, A. and Pulgar, J. A. 1988. A thin-skinned tectonics model for an arcuate fold and thrust belt: the Cantabrian Zone (Variscan Ibero-Armorican Arc). Tectonics, 7, 517-537.

Perret, M. F. 1993. Recherches micropaléontologiqeus et biostratigraphiques dans le Carbonifère pyrénéen. Strata, sér. 2, 21, 1-597.

Perret, M. F. et Vachard, D. 1977. Algues et pseudo-algues des calcaires serpoukhoviens d'Ardengost (Hautes Pyrénées). Annales de Paléontologie, 63, 85-156.

Pia, J. 1912. Neue Studien über die Triadischen Siphoneae Verticillatae. Beitrage Paläontologie-Geologie, Österreich-Ungaru, 25, 25-85.

Pia, J. 1920. Die Siphoneae verticillatae vom Karbon bis zur Kreide. Abhandlung zoologisch-botanischen Gesellschaft im Wien, Band XI, 2, 1-263.

Pia, J. 1922. Einige Ergebnisse neuerer Untersuchungen über die Geschichte der Siphoneae verticillatae. Zeitschrift fur induktive Abstammungs-und Vererbungslehre, Band XXX, 63-98.

Pia, J. 1927. Abteilung: Thallophyta. In: Handbuch der Paläobotanik, Band I. M. Hirmer Press, München und Berlin, 31-136.

Pia, J. 1937. Die wichtigsten Kalkalgen des Jungpaläozoikums und ihre geologische Bedeutung. Deuxième Congrès pour l'Avancement de la Stratigraphie du Carbonifère, 2, 765-856.

Poncet, J. 1986. Les Algues calcaires du Carbonifère moyen du Bassin de Béchar (Sahara algérien). Revue de Micropaléontologie, 29, 187-197.

Poncet, J. 1989. Cheggatella lenticula n. gen., n. sp., Algue rouge calcaire du Carbonifère supérieur du Bassin de Béchar (Sahara algérien). Géobios, 22, 677-682.

Proust, J. N., Vennin, E., Vachard, D. et al. 1996. Etude sédimentologique et biostratigraphique du stratotype du Bashkirien (Oural du Sud, Russie). Bulletin du Centre de Recherche Exploration-Production Elf-Aquitaine, 20, 341-365.

Rácz, L. 1966a. Carboniferous calcareous algae and their association in the San Emiliano and Lois-Ciguera formations (Province of León, northwest Spain). Leidse Geologische Mededelingen, 31, year 1964, 1-112.

Rácz, L. 1966b. Late Paleozoic calcareous algae in the Pisuerga Basin (North Palencia, Spain). Leidse Geologische Mededelingen, 31, year 1964, 241-260.

Rácz, L. 1984. Iberiella, a new fossil alga from the Middle Carboniferous of N. W. Spain. Geologie en Mijnbouw, 63, 333-336.

Radionova, E. P. 1979. Algae from the Elergethym Suite (Omolon Massif) (in Russian, translated). Field excursion guidebook for Tour IX, XIV Pacific Science Congress, 52-62. 

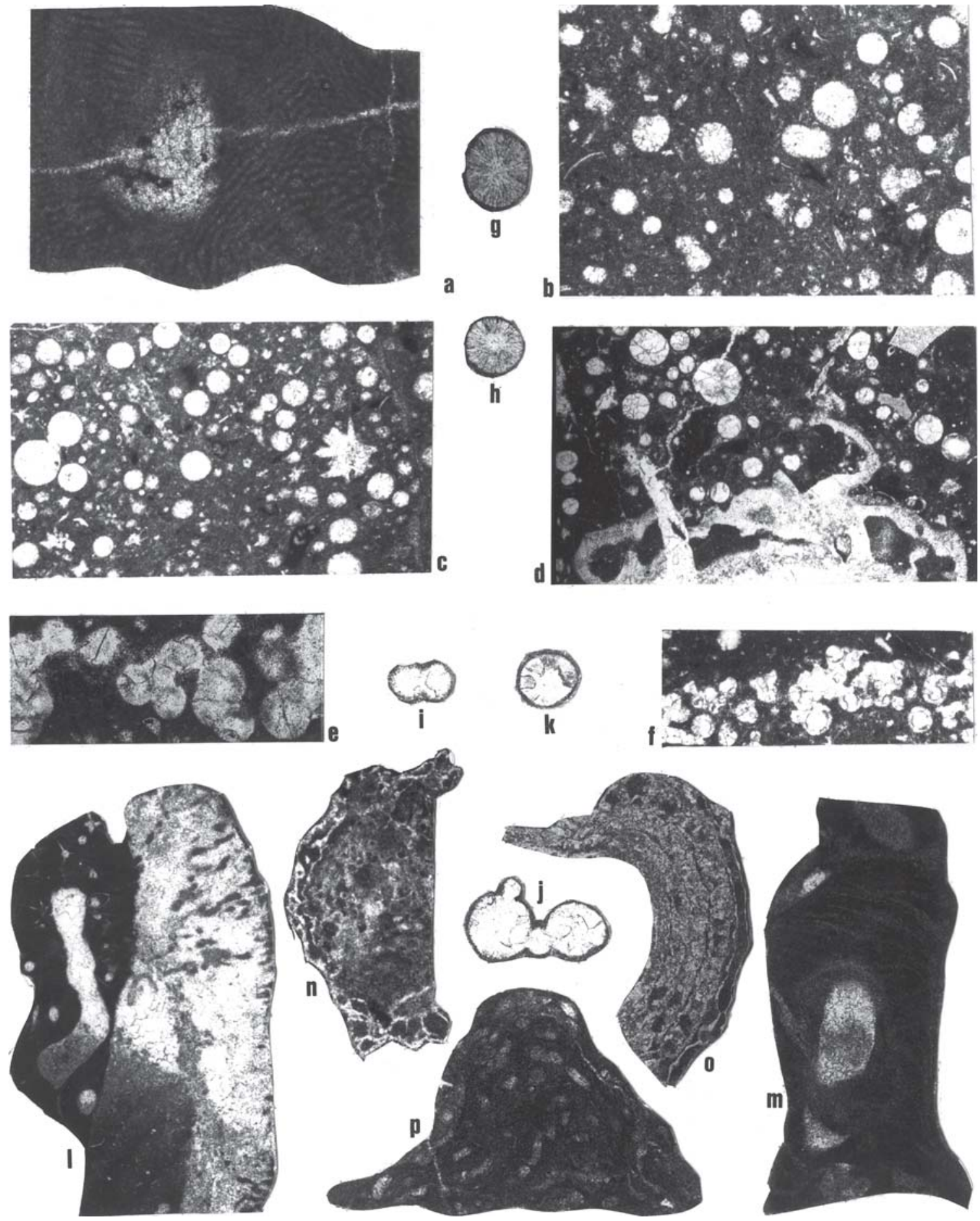

Figure 15. b-k, Penella pongaensis n. gen., n. sp.; b, U. of M. 825/2, BM-251, Inguanzo, x41; swarms of cement filled Penella, sponge spicules and ostracods; c, U. of M. 825/3, same as a; budding Penella, microscleres, macroscleres and sessile foraminifer; d, U. of M. 816/20, BM-85, Pen section, x62; cement filled Penella with remnants of wall, Anthracoporellopsis, sponge microscleres and echinoderm plates; e, U. of M. 816/18, BM-79, Pen section, x62; f, U. of M. 816/22, as d, but x30; g, U. of M. 818/1, BM-98, Berodia-I section, x97; filled by neomorphic cement; h, U. of M. 818/2, BM-78, Pen section, x97; i, U. of M. 816/21a, as d; j, U. of M. 816/21b, as d, Holotype; k, U. of M. 816/21c, as d. a, l-m, Tubiphytes obscurus Maslov 1956 [=Shamovella obscura (Maslov 1956)]; a, U. of M. 948/15, BM-FER 147, entrance of Marble Canyon, British Columbia, Cache Creek Formation, Roadian, associated with Codonofusiella-Kahlerina, x121; collected with C. Ross and F. Kobayashi; 1, U. of M. 814/23, BM-76B, Las Llacerias section, x26. Encrusting Anthracoporella; note in the tissue the presence of sponge sclerites and of an ostracod; they do not suggest that Tubiphytes is either a sponge or an arthropod; m, U. of M. 818/16, BM-122, Berodia-II section, x30. Note the growth surfaces. n, Claracrusta? sp., U. of M. 810/0, BM-28, Las Llacerias section, x26. o, Claracrusta catenoides (Homann 1972), U. of M. 815/8, BM-78, Pen section, x62. p, Ellesmerella permica (Pia 1937), U. of M. 728/4, BM-52, Las Llacerias section, x62. 
Ramovs̆, A. 1971. Biostratigraphische charakteristik der Oberkarbon-Schichten in den Sudkarawanken, N. W. Jugoslavien. Compte Rendu, Congrès International de Stratigraphie et Géologie du Carbonifère, Sheffield, 1967, 4, 1387-1394.

Ramovs̆, A. 1978. Okamnelo zivljenje v jeseniskem prostoru. Vodnik po paleontoloski zbirki tekniskega muzeja Jesenice, 1-80.

Ramovš, A. and Kochansky-Devidé, W. 1981. Karbon and Permian beds near Logu in the Julian Alps. Geologija, 24, 91-107.

Rauzer-Chernousova, D. M. 1948. Viséan stratigraphy of the southern part of the Podmoscovian Basin after foraminifers (in Russian, translated). Akademija Nauk SSSR, Trudy Institut Geologii (geol. ser. 19), 62, 3-40.

Rauzer-Chernousova, D. M. and Koroljuk, I. K. 1981. On the morphology and systematic of Late Moscovian Siphonal algae in the South Urals and their significance in rock formation (in Russian, translated). Voprosy Mikropaleontologii, 24, 157-170.

Razgallah, S. et Vachard, D. 1991. Systématique et biosédimentologie des Algues constructrices permiennes Tubiphytes et Archaeolithoporella suivant l'exemple du Jebel Tebaga. Palaeontographica, B, 221, 171-205.

Razgallah, S., Chaouachi, M. C. et M'Rabet, A. 1989. Les récifs à Algues du Permien Supérieur du Jebel Tebaga du Médenine, Sud-Est de la Tunisie. Géologie Méditerranéenne, 6, 213-231.

Riding, R. 1979. Bioherms à Donezella dans le Carbonifère des Cantabriques méridionales, Espagne. Bulletin du Centre de Recherches Exploration-Production, Elf-Aquitaine, 3, 787-794.

Riding, R. (Ed.) 1991. Calcareous Algae and Stromatolites. Springer-Verlag, Berlin, 571 pp.

Riding, R. 1993. Shamovella obscura: the correct name for Tubiphytes obscurus (Fossil). Taxon, 42, 71-73.

Riding, R. 2000. Microbial carbonates: the geological record of calcified bacterial-algal mats and biofilms. Sedimentology, 47, 179-214.

Riding, R. and Awramic, S. M. (Eds.) 2000. Microbial Sediments. Springer-Verlag, Berlin, $331 \mathrm{pp}$.

Rodríguez, S. y Moreno-Eiris, E. 1986. Microfacies de Algas y Corales del Kasimoviense del norte de Picos de Europa, N. de España. Acta Geologica Hispanica, 21-22, 521-527.

Roux, A. 1979. Révision du genre Epimastopora "Pia, 1922" (Dasycladaceae). Bulletin Centre Recherches Exploration-Production Elf-Aquitaine, 3, 803-810.

Saltovskayav. D. 1984. On some new Paleozoic algae of Tadzikhistan. In: New species of calcareous flora and fauna of Tadzikhistan (in Russian, translated). Akademija Nauk Tadzikhoe SSR, Institut Geologii, Tadzikhoe Otdelenie Vseseyonogo Paleontologicheskogo Obschestva, 141-160.

Samankassou, E. 2001. Internal structure and depositional environment of Late Carboniferous mounds from the San Emiliano Formation, Cármenes Syncline, Cantabrian Mountains, northern Spain. Sedimentary Geology, 145, 235-252.
Samankassou, E. 2002. Cool-water carbonates in a paleoequatorial shallow-water environment: the paradox of the Auernig cyclic sedimentation (Upper Pennsylvaniaan, Carnic Alps, Austria-Italy). Geology, 30, 655-658.

Sánchez de Posada, L. C., Villa, E., Martínez-Chacón, M. L., Rodríguez, R. M., Rodríguez, S. y Coquel, R. 1999. Contenido paleontológico y edad de la sucesión de Demués (Carbonífero, Zona Cantábrica). Trabajos de Geología, 21, 339-352.

Sánchez de Posada, L. C., Villa, E., Rodríguez, R. M., Martínez-Chacón, M. L., Rodríguez, S. and Coquel, R. 2002. Paleontological content of the Demués section (Upper Carboniferous, Cantabrian Mountains, Spain) and their significance in correlation. Canadian Society Petroleum Geologists Memoir, 19, 588-595.

Sánchez-Chico, F., Mamet, B., Moreno-Eiris, E. y Rodríguez, S. 1995. Algas calcáreas del Viseense de los Santos de Maimona (Badajoz). Revista Española de Micropaleontología, 27, 67-96.

Sano, H. and Kanmera, K. 1996. Microbial controls on Panthalassan Carboniferous-Permian oceanic buildups, Japan. Facies, 34, 239-256.

Schafhaütl, K. E. 1853. Beiträge zur näheren Kenntnis der Bayern'schen Voralpen. Neues Jahrbuch für Mineralogie, Geologie und Paläontologie, 299-319.

Sebbar, A. 1990. Algues calcaires serpukhoviennes (Carbonifère Inférieur) du Bassin de Béchar, Algérie. Revue de Micropaléontologie, 33, 138-143.

Sebbar, A. 1998. Foraminiféres et Algues calcaires du Carbonifére, Bassin de Reganne, Sahara Central. Bulletin Service Geologique d'Algérie, 9, 123-147.

Sebbar, A. et Lys, M. 1989. Biostratigraphie du Carbonifère Inférieur: Serpukhovien du Djebel Arlal, Bassin de Béchar, Algérie. Revue de Micropaléontologie, 32, 53-62.

Sebbar, A. et Mamet, B. 1996. Algues bentiques calcaires du Carbonifére Inférieur et Moyen, Bassin de Béchar, Algérie. Revue de Micropaléontologie, 39, 153-167.

Sebbar, A. et Mamet, B. 1999. Algues benthiques calcaires et incertae sedis du Carbonifère, Bassin de "BécharMézarif”, Algérie. Rôle sédimentologique. Revue de Micropaléontologie, 42, 71-82.

Senowbari-Daryan, B. and Flügel, E. 1993. Tubiphytes Maslov, an enigmatic Fossil: Classification, Fossil record and Significance through time. In: Studies on Fossil Benthic Algae (Ed. F. Barattolo et al.). Bolletino della Società Paleontologica Italiana, sp. vol. 1, 353-382.

Shuisky, V. P. 1987. Green algae (Chlorophytes) (in Russian, translated). In: Fossil Calcareous Algae (Ed. V. I. Dubatolov). Akademija Nauk SSSR, Sibirskoe Otdelenie, Trudy Institut Geologii i Geofizikii, 674, 38-109.

Skipp, B., Baeseman J. and Brenkle, P. L. 1985. A reference area for the Mississippian-Pennsylvanian (Mid-Carboniferous) boundary in East-Central Idaho, U. S. A. 10 $10^{\text {ième }}$ Congrès International de Stratigraphie et Géologie du Carbonifère, Madrid 1983, 4, 403-428.

Skompski, S. 1986. Upper Viséan calcareous algae from the Lublin Coal Basin. Acta Geologica Polonica, 36, 251-280. 
Skompski, S. 1993. Shell structure and affinity of the Carboniferous Saccamminopsis. Lethaia, 26, 147-152.

Skompski, S. 1996. Stratigraphic position and facies significance of the limestone bands in the subsurface Carboniferous succession of the Lublin Upland. Acta Geologica Polonica, 46, 171-268.

Skompski, S., Conil, R., Laloux, M. et Lys, M. 1989. Etude micropaléontologique des calcaires du Viséen terminal et du Namurian dans le bassin carbonifère de Lubli, à l'Est de la Pologne. Bulletin de la Société belge de Géologie, 98, 353-369.

Stanton, R. J., Conolly, N. M. and Lambert, L. L. 1994. Paleoecology of Upper Carboniferous Chaetetes - morphology, growth and spatial distribution. Courier Forschungsinstitut Senckenberg, 172, 365-372.

Stolley, E. 1893. Ueber silurische Siphoneen. Neues Jahrbuch fur Mineralogie, Geologie und Paläontologie, II Band, 135-146.

Termier, H., Termier, G. et Vachard, D. 1977. Monographie paléontologique des affleurements permiens du Djebel Tebaga (Sud Tunisien). Palaeontographica, A, 156, 1109.

Toomey, D. F. 1969. The biota of the Pennsylvanian (Virgilian) Leavenworth Limestone, Midcontinent region. Part I: Stratigraphy, paleogeography and sediment facies relationships. Journal of Palentology, 43, 1000-1018.

Toomey, D. F. 1983. The Paleoecology of a "Middle Limestone Member" (Leavenworth Limestone) of an Upper Carboniferous (Stephanian) Cyclothem, Midcontinent, U. S. A. Facies, 8, 113-190.

Torres, A. M. 1997. Reconstruction of a cyathiform Eugonophyllum, Upper Pennsylvanian, Palo Pinto Co, Texas. Journal of Paleontology, 71, 493-499.

Torres, A. M. and Baars, D. L. 1992. Anchicodium Johnson: branched or phylloid? Journal of Paleontology, 66, 675677.

Vachard, D. 1981. Tethys et Gondwana au Paléozoique Supérieur. Les données afghanes. Documents et Travaux de l'Institut géologique A. de Lapparent, 2, 1-463.

Vachard, D. 1985. Remarques sur les Dasycladales (Algues vertes) du Permien supérieur du Djebel Tebaga. Actes Premier Congrès National Sciences de la Terre, Tunis, 271-278.

Vachard, D. 1991. Parathuramminidés et Moravamminidés (Microproblematica) de l'Emsien Supérieur de la Formation Moniella (Cordillères Cantabriques), Espagne. Revue de Paléobiologie, 10, 255-299.

Vachard, D. 1993. Fusulinidos del Guadalupiano superior (Pérmico) de Olinala, Guerrero, Mexico. Revista Mexicana del Petróleo, 25, 5-19.

Vachard, D. et Beckary, S. 1991. Algues et Foraminifères bachkiriens des Coal Balls de la mine Rosario (Truébano, León, Espagne). Revue de Paléobiologie, 10, 315-357.

Vachard, D. et Berkhli, M. 1992. Importance des coupes du Bassin de Djerada (Maroc) pour la connaissance du Viséen terminal. Revue de Micropaléontologie, 35, 307328.

Vachard, D. and Clement, B. 1994. L'Hastarien (ex Tournai- sien) á algues et Foraminiféres de la zone pélagonienne (Attique, Grêce). Revue de Micropaléontologie, 37, 289319.

Vachard, D. et Clift, P. 1993. Une association à Pseudodunbarula (Fusulinoide) du Permien Supérieur (Djoulfien) remaniée dans le Jurassique d'Argolide (Péloponèse, Grèce). Revue de Paléobiologie, 12, 217-242.

Vachard, D. et Ferrière, J. 1991. Une association à Yabeina dans le Midien de la règion de Wangaora (Baie d'Orna, Nouvelle-Zélande). Revue de Micropaléontologie, 34, 201-230.

Vachard, D. et Fourcade, E. 1997. Foraminiféres et Algues du Permien du Guatemala. Geobios, 30, 745-784.

Vachard, D. and Krainer, K. 2001. Smaller foraminifers, characteristic algae and pseudo-algae of the latest Carboniferous-Early Permian Rattendorf Group, Carnic Alps (Austria /Italy). Rivista Italiana di Paleontologia e Stratigrafia, 107, 169-195.

Vachard, D. et Maslo, A. 1996, Précisions biostratigraphiques et micropaléontologiques sur le Bashkirien d'Ukraine (Carbonifére Moyen). Revue de Paléobiologie, 15, 357383.

Vachard, D. and Montenat, C. 1981. Biostratigraphie, micropaléontologie et paléogéographie du Permien de la région de Tezak (Montagnes Centrales d'Afghanistan). Palaeontolographica, 178, B, 1-88.

Vachard, D. et Tahiri, A. 1991. Foraminifères, Algues et pseudo-algues du Viséen de la région d'Oulmes (Maroc). Géologie méditerranéenne, 18, 21-41.

Vachard, D., Gargouri-Razgallah, S. and Chaouachi, M. C. 1989. Sur les biohermes à algues Solénoporacées et Phylloides du Permien supérieur de Tunisie (Murghabien du Djebel Tebaga). Revue de Paléobiologie, 8, 121-141.

Vachard, D., Martini, R., Zaninetti, L. et Zambetakis-Leklas, A. 1993. Révision micropaléontologique (Foraminifères, Algues) du Permien inférieur (Sakmarien) et supérieur (Dorashamien) du Mont Beletsi (Attique, Grèce). Bolletino della Società Paleontologica Italiana, 32, 89-112.

Vachard, D., Flores de Dios, A. et Buitron, B. E. 1997. Sur une nouvelle localité à Fusulines du Wordien (Permien Supérieur) du Mexique: Conséquences paléogéographiques. Géobios, 30, 361-370.

Vachard, D., Hauser, M., Martini, R., Zaninetti, L., Matter, A. and Peters, T. 2001a. New algae and problematica of algal affinity from the Permian of the Asselah Unit of the Batain Plain (East Oman). Géobios, 34, 375-404.

Vachard, D., Martini, R. and Zaninetti, L. 2001b. Earliest Artinskian (Early Permian) fusulinids reworked in the Triassic Lercara Formation (NW Sicily). Journal of Foraminiferal Research, 31, 33-47.

Vennin, E., Boisseau, Th., Proust, J. and Chuvashov, B. 2002. Influence of eustasy and tectonism on reef architecture in Early Permian reef complexes, southern Utah. Society of Economic Paleontologists and Mineralogists (SEPM), Special Publication, 74, 207-218.

Venturini, C., Pondrelli, M. and Pasini, M. 1998. Stratigraphic and tectonic evolution of the uppermost Carboniferous succession of the eastern Asturian Basin (Gamo- 
nedo-Arenas de Cabrales area), Cantabrian Mts. (NW Spain). Giornale di Geologia, ser. 33, 60, 167-196.

Villa, E. 1995. Fusulináceos carboníferos del este de Asturias (N de España). Biostratigraphie du Paléozoïque, 13, 1261.

Villa, E. and Bahamonde, J. R. 2001. Accumulations of Ferganites (Foraminifera, Fusulinacea) in catastrophic flooding-related deposits from the Carboniferous of Spain. Journal of Foraminiferal Research, 31, 173-190.

Villa, E. and Ginkel, A. C. van 1999. First record of Gzhelian fusulinaceans from the Carboniferous of northern Spain. Revista Española de Paleontología, N. ${ }^{\circ}$ extr. Homenaje al Prof. J. Truyols, 205-216.

Villa, E. and Ginkel, A. C. van 2000. Some late Moscovian and Kasimovian fusulinaceans from the Las Llacerias section (Cantabrian Mountains, Spain). Journal of Foraminiferal Research, 30, 219-243.

Villa, E. y Martínez García, E. 1989. El Carbonífero Superior marino de Dobros (Picos de Europa, Asturias, NW de España). Trabajos de Geología, 18, 77-93.

Villa, E. and Ueno, K. 2002. Characteristics and paleogeographic affinities of the early Gzhelian fusulinoideans from the Cantabrian Zone (NW Spain). Journal of Foraminiferal Research, 32, 135-154.

Villa, E., Ginkel, A. C. van, Leyva, F., Martínez-Chacón, M. L., Méndez, C., Rodríguez-González, R. M., Rodríguez, S. and Sánchez de Posada, L. C. 1993. Fossil content of the Moscovian-Kasimovian boundary in a section of the Picos de Europa area (Carboniferous, NW Spain). Compte Rendue XII ICC-P, Buenos Aires, 2, 385-406.

Villa, E., Alekseev, A. S., Barskov, I. S., Coquel., R., Davydov, V. I., Ginkel, A. C. van, Goreva, N. V., Isakova, T. N., Kabanov, P. B., Kononova, L. I., Lazarev, S. S., Lebedev, O. A., Makhlina, M. Kh., Mamet, B., MartínezChacón, M. L., Méndez, C., Rodríguez, R. M., Rodríguez, S. Sánchez de Posada, L. C., and Shkolin, A. V. 1997. Palaeontological analysis and comparison of the Moscovian/Kasimovian transition in the Moscow Basin (Russia) and in the Cantabrian Mountains (Spain). Proceedings of the XIII International Congress on the Carboniferous and Permian, Krakow, Poland, 1, 173-185.
Villa, E., Dzhenchuraeva, A., Forke, H. C. and Ueno, K. 2002. Distinctive features of Late Carboniferous fusulinoidean faunas from the western Paleo-Tethyan realm. In: Carboniferous and Permian of the World (Eds. L. V. Hills, C. M. Henderson, and E. W. Bamber). Canadian Society of Petroleum Geologists Memoir, Calgary, 19, 609-615.

Villa, E., Merino-Tomé, O., Bahamonde, J. R. and Ueno, K. 2003. Fusulinoideans from the Puentellés Formation (Upper Carboniferous, NW Spain): Discussion on phylogeny, paleoecology and paleobiogeography. Rivista Italiana di Paleontologia e Stratigrafia, 109, 241-253.

Wahlman, G. 1988. Subsurface Wolfcampian (Lower Permian) shelf-margin reefs in the Permian Basin of West Texas and southeastern New Mexico. Society of Economic Paleontologists and Mineralogists (SEPM), Special Publication, 1, 177-204.

Wahlman, G. 2002. Upper Carboniferous-Lower Permian (Bashkirian-Kungurian) mounds and reefs. Soc Society of Economic Paleontologists and Mineralogists (SEPM), Special Publication, 72, 271-338.

Wahlman, G. and Konovalova, M. 2002. Upper Carboniferous-Lower Permian Kozhim carbonate bank, subpolar pre-Ural Mountains, northern Russia. Society of Economic Paleontologists and Mineralogists (SEPM), Special Publication, 74, 219-241.

Weidlich, D. and Fagerstrom, J. A. 1999. Influence of sealevel changes on development, community structure and composition of the Upper Capitan Guadalupe Mountains, Texas and New Mexico. Society of Economic Paleontologists and Mineralogists (SEPM), Special Publication, 65, 139-160.

Wray, J. L. 1977. Calcareous algae. Elsevier, Amsterdam, $185 \mathrm{pp}$.

Zadorodnjuk, P. A. 1979. Algae. In: Atlas of Middle-Upper Carboniferous fauna and flora of Bashkiria (Ed. O. L. Einor) (in Russian, translated ). Kiev Gosudav. Universitet T. G Chevchenko, 6-12.

Manuscrito recibido: 22 de marzo, 2004 Manuscrito aceptado: 14 de septiembre, 2004 